University of Wollongong

Research Online

Faculty of Business - Papers (Archive)

Faculty of Business and Law

$1-1-2016$

\title{
Towards a Set of Design Principles for Executive Compensation Contracts
}

Yaowen Shan

University of Technology Sydney

Terry S. Walter

University of Sydney, twalter@uow.edu.au

Follow this and additional works at: https://ro.uow.edu.au/buspapers

Part of the Business Commons

Research Online is the open access institutional repository for the University of Wollongong. For further information contact the UOW Library: research-pubs@uow.edu.au 


\title{
Towards a Set of Design Principles for Executive Compensation Contracts
}

\begin{abstract}
Executive compensation has been controversial for many years. Controversies over executive pay have sparked outrage from some sectors and calls for increased regulation and reform. Yet others argue that knee-jerk reactions to perceived abuses of pay can lead to a host of unintended and inefficient outcomes. This paper argues that much of this controversy is due to executives being rewarded via contracts that have weaknesses in design. We argue that few stakeholders in firms would object to generous compensation for managers whose performance results in abnormally high long-term shareholder wealth creation. We state a set of principles, developed from a review of the extensive theoretical, regulatory, and empirical literature, that we offer as fundamental building blocks for designing executive remuneration systems in public firms, especially where ownership and control are separated. Our purpose is to generate broad debate and discussion leading to a consensus as to the principles that should be present in all executive compensation contracts such that the interests of shareholders and managers are more closely aligned.
\end{abstract}

\section{Disciplines}

Business

\section{Publication Details}

Shan, Y. \& Walter, T. (2016). Towards a Set of Design Principles for Executive Compensation Contracts. Abacus: a journal of accounting, finance and business studies, 52 (4), 619-684. 


\title{
Towards a Set of Design Principles for Executive Compensation Contracts*
}

\author{
Yaowen Shan ${ }^{1}$ and Terry Walter ${ }^{2}$
}

This Draft May 2014

\footnotetext{
${ }^{1}$ Discipline of Accounting, UTS Business School

${ }^{2}$ Discipline of Finance, University of Sydney Business School
}

\begin{abstract}
Executive compensation has been controversial for several decades. Recent controversies over executive pay have sparked outrage from some sectors and calls for increased regulation and reform. Yet others argue that knee-jerk reactions to perceived abuses of pay can lead to a host of unintended and inefficient outcomes. This paper argues that much of this controversy is due to executives being rewarded via contracts that have weaknesses in design. We argue that few stakeholders in firms would object to generous compensation for managers whose performance results in abnormally high longterm shareholder wealth creation. We state a set of principles, developed from a review of the extensive theoretical, regulatory and empirical literature, that we suggest should be the fundamental building blocks for designing executive remuneration systems in public firms, especially where ownership and control is separated. Our purpose is to generate broad debate and discussion leading to a consensus as to the principles that should be present in all executive compensation contracts such that the interests of shareholders and managers are aligned.
\end{abstract}

\footnotetext{
* We are grateful for suggestions by Alex Frino, Doug Foster, Talis Putnins, as well as workshop participants at Macquarie University, Massy University, Queensland University of Technology and the University of South Australia.
} 


\section{INTRODUCTION}

CEO compensation is controversial. While some examples of CEO misbehaviour are quite recent and thus well-remembered ${ }^{1}$, Murphy (2013) demonstrates that CEO pay was controversial in the US even before the Great Depression of the 1930s.

CEOs of public companies are routinely perceived to be overpaid and their boards are perceived to provide poor monitoring and control of powerful executives. There are three elements to these complaints (Kaplan, 2013), namely that (i) CEOs are overpaid and their pay keeps increasing; (ii) CEO pay is not linked to performance; and (iii) corporate boards are ineffective monitors. Bebchuk and Fried $(2005$, p. 2) claim that, "flawed compensation arrangements have not been limited to a small number of 'bad apples'; they have been widespread, persistent, and systemic".

The US regulatory response to the Enron and WorldCom collapses (among many other high profile failures) was to introduce far-reaching corporate governance reforms in the Sarbanes-Oxley legislation of 2002, while the Dodd-Frank legislation of 2010 followed the global financial crisis (GFC). Dodd-Frank requires that, among many other things, all public companies obtain an annual advisory shareholder vote on top executive pay $^{2}$. The Australian response to perceived abuses of termination payments resulted in amendments to the Corporations Act 2001 that restrict giving benefits greater than one year's base salary on retirement from a board or managerial office, unless shareholders approve the benefit. Australian remuneration rules were also recently, and many argue controversially, amended to introduce the 'two strikes' rule which became effective from 1 July $2011^{3}$. Under the two strikes rule, if 25 per cent of shareholders at a company's annual general meeting (AGM) vote against the company's remuneration report the first time, directors are put on notice to review their remuneration policies. The second and final strike is delivered if, at the following year's AGM, 25 per cent of shareholders again vote against the remuneration report. Further, if at least 50 per cent of shareholders present at the meeting vote for a board spill, directors must face re-election within 90 days ${ }^{4}$. However, whether these

\footnotetext{
${ }^{1}$ For example, the Enron and WorldCom collapse, the US option backdating scandal of the early-2000s, high-risk lending in the US residential real estate market and compensation systems that encouraged excessive risk-taking in financial institutions which led, among many other factors, to the global financial crisis, and termination payments that were perceived to be overly generous.

${ }^{2}$ Kaplan (2013) shows that top executive pay policies at over $98 \%$ of S\&P 500 and Russell 3000 companies received majority shareholder support in the Dodd-Frank mandated 'Say-On-Pay' votes in 2011.

${ }^{3}$ The Corporations Amendment (Improving Accountability on Director and Executive Remuneration) Act 201 (Cth). ${ }^{4}$ Lee and Shan (2014) have a current research project on the two strikes rule in Australia. They find that, among all ASX listed firms, there are 99 first strikes in 2011, and 124 strikes in 2012. Twenty-three of these firms have two
} 
regulatory reforms will achieve their intentions without severe unintended consequences remains somewhat clouded. A central theme of Murphy (2013)'s paper is that the history of regulatory intervention into CEO pay in the US suggests that unintended consequences abound.

This paper argues that much of this controversy is due to executives being rewarded via contracts that have weaknesses in design. We argue that few stakeholders in firms would object to generous compensation for managers whose performance results in abnormally high long-term shareholder wealth creation. We state a set of principles, developed from a review of the extensive theoretical, regulatory and empirical literature, that we suggest should be the fundamental building blocks for designing executive remuneration systems in public firms, especially where ownership and control is separated. Our purpose is to generate broad debate and discussion, hopefully leading to a consensus as to the principles that should be present in all executive compensation contracts such that the interests of shareholders and managers are aligned.

\section{THEORIES OF EXECUTIVE COMPENSATION}

There are two main 'camps' in relation to CEO compensation, and it is quite clear that opinions are dramatically and sometimes heatedly divided ${ }^{5}$. One group of researchers, the efficient contracting camp, argues and finds that CEO compensation is set in a competitive equilibrium with appropriate incentive structures to motivate managers to maximize shareholder wealth. The other dominant group, the managerial power camp, argues that CEO compensation is set through managers exercising power over ineffective boards of directors. The two groups engage in robust debate, though occasionally this becomes somewhat inflamed.

Murphy (2013) suggests that any discussion of CEO compensation that ignores developments in government regulatory and tax policy in relation to the CEO pay controversy is likely to ignore an important aspect of the way in which executive pay, particularly in the US, has evolved. Thus a third

strikes in 2012. Their preliminary results also show that the market reaction following the AGM meeting for a 'first strike' in 2011 is negative and significant.

${ }^{5}$ Bertrand (2009) reviews three main explanations: a principle-agent view, a rent extraction view and a marketbased view. The market-based view argues that the market has played an increasingly important role in setting CEO compensation because a growing share of CEOs are externally recruited as the demand for CEOs shifts away from firm-specific skills toward more general skills. This shift has intensified the competition among firms for managerial talent, resulting in higher equilibrium compensation in the CEO market (see section 3.2.3 in Bertrand 2009). The market-based view can be considered to be a part of the efficient contracting perspective. 
aspect of executive compensation considers regulatory issues, and in particular some of the unintended consequences of regulatory reform of CEO remuneration. Finally, CEOs are subject to the laws of the land, and these laws spell out the legal obligations of executives of corporations. It is interesting to note that both Australian and US corporations law ${ }^{6}$ requires that directors and officers put the interests of the corporation before their own interests.

\subsection{Efficient Contracting Theories}

The efficient-contracting camp, with its theoretical roots in optimal contracting theory, maintains that the "observed level and composition of compensation reflects a competitive equilibrium in the market for managerial talent, and that incentives are structured to optimize firm value" (Murphy, 2013, p. 214). One often-discussed benefit of equity-based compensation is that this can reduce agency costs associated with the separation of ownership and control (see Berle and Means, 1932 and Jensen and Meckling, 1976) by better aligning the incentives of the CEO with those of the shareholders. Smith and Watts (1982) describe long-term incentive plans as a means whereby agency costs can be controlled, in particular costs associated with a manager's risk aversion. Managers have a considerable portion of their wealth tied up in the firms they manage and hence they hold a portfolio with considerable exposure to firm-specific (idiosyncratic) risk. This may cause them to be risk averse in their investment and financing decisions for the firms they manage. Shareholders, on the other hand, can easily diversify away from such firm-specific risks and hence want to encourage managerial risk taking. One way in which this conflict can be reduced is to tie management compensation to firm performance, thus motivating managers to make shareholder value-increasing decisions and improving the payperformance sensitivity (see also Holmstrom, 1979, Harris and Raviv, 1979, Grossman and Hart, 1983 and Smith and Stulz, 1985).

Hirshleifer and Suh (1992) argue that option-based managerial compensation can reduce agency costs associated with both risk aversion and incentives to reduce effort. Consequently, shareholders would prefer the composition of executive remuneration to contain more equity-linked payments than cash payments. However, it needs to be remembered that the value a CEO places on a share of restricted stock or the grant of an executive option "will be strictly less than the fair market value of the share" (Murphy, 2013, p. 229).

\footnotetext{
${ }^{6}$ The US business judgment rule specifies that the court will not review the business decisions of directors who performed their duties (1) in good faith (2) with the care that an ordinarily prudent person in a like position would exercise under similar circumstances; and (3) in a manner the directors reasonably believe to be in the best interests of the corporation. The Australian Corporations Act 2001 (s 180) contains similar provisions.
} 
Shleifer and Vishny (1997) argue that in the case of incomplete contracting where managers have more information than outsiders (i.e., analysts and shareholders) managers have residual control rights that provide incentives for self-interested behaviour. Long-term equity based compensation offers one solution to this problem, accordingly firm performance is positively affected when managers are granted equity-based compensation.

\subsection{Managerial Power Theories}

The managerial power camp argues that both the level and composition of CEO pay is determined through managers exercising their power over captive boards. A series of papers by Yermack (1995, 1997, 2006a, 2006b, 2009), Bebchuk and Fried (2003, 2004, 2006), Bebchuk et al. $(2002,2010)$ and Bebchuk and Grinstein (2005) exemplify this view. Yermack (1995) finds that few agency and financial contracting theories have explanatory power for patterns of CEO stock option awards, while Yermack (2006a) focuses on a CEO's personal use of corporate jets, finding that firms that disclose this managerial benefit underperform by more than four per cent annually. An initial disclosure announcement share price effect of -1.1 per cent is documented. Yermack (2006b) studies the severance pay of 179 CEOs who left Fortune 500 firms, showing that more than half receive severance pay worth on average \$US 5.4 million. A large majority of this severance pay is made on a discretional basis by the board of directors, not in accord with the CEO's employment contract. Yermack (2009) samples 1,013 major gifts by CEOs to their family foundations between 2003 and 2005 and finds that CEOs make their gifts just before their stock price falls, maximizing their income tax refunds.

Bebchuk et al. (2002) and Bebchuk and Fried (2003) argue that managerial power and rent extraction are likely to have an important influence on the design of executive compensation contracts, while Bebchuk and Fried (2006) argue a similar case of managerial capture. Their 2004 book provides a "detailed account of how corporate boards have failed to negotiate with executives and how pay practices have decoupled compensation from performance, leading to practices that dilute manager incentives and hurt shareholders" (Bebchuk and Fried, 2006, p. 2). They argue that making board decision-making at arm's length from the power of CEOs is tortuous and that substantial additional corporate governance reform is necessary to give shareholders greater scrutiny over boards, and boards greater control over CEOs. Bebchuk and Fried (2004) show that US boards have been able to camouflage substantial amounts of executive remuneration through the use of payments made on retirement of executives. 
Bebchuk et al. (2010) study the timing of CEO option grants, a topic that has been subject to considerable recent SEC legal action, resulting in dozens of US CEOs and directors being forced to resign. The 2010 study finds: "Overall, our analysis provides support for the view that opportunistic timing practices reflect governance breakdowns and raise governance concerns. In particular, we find that: opportunistic timing was correlated with factors associated with greater CEO influence on corporate decision-making, such as a lack of a majority of independent directors or a long-serving CEO; grants to independent directors were also opportunistically timed, and this timing was not merely a byproduct of simultaneous awards to executives or of firms routinely timing all option grants; and lucky grants to independent directors were associated with more CEO luck and CEO compensation". (p. 2364) Bebchuk and Grinstein (2005) examine the growth of US executive pay during the period 1993-2003. They show that pay increased by substantially more that can be explained by changes in firm size, performance, and industry classification. Mean compensation in 2003 would have been only about half its actual size had the relationships that existed in 1993 been maintained. Equity-based compensation increased considerably for both new-economy and old-economy firms; this growth was not accompanied by a reduction in non-equity rewards.

\subsection{Unintended Regulatory Consequences}

Murphy (2013) comprehensively reviews the evolution of executive pay in the US with a particular emphasis on the role of government intervention. He argues that the 'efficient contracting' and 'managerial power' camps are not mutually exclusive. As an example, he argues that a series of papers (Murphy, 2002, Murphy 2003 and Hall and Murphy, 2003) show that the escalation of option grants in the 1990s was because boards and executives (erroneously) regarded option grants as being free. Murphy (2013) argues that treating the two theories (efficient contracting and managerial power) of managerial compensation as competing hypotheses has not been productive, because they ignore critical political, tax, accounting and other influences on managerial pay. In Section 3 of this paper, Murphy develops the central theme of his study, namely that government intervention has been "both a response to and a major driver of time trends in executive compensation over the past century, and that any explanation for pay that ignores political factors is critically incomplete" Murphy (2013, p. 249). This review spans the controversy over executive compensation and the regulatory responses from the 30 years before the Great Depression, during the Great Depression of the 1930s, during the rise (and fall) of the use of restricted stock options between 1950-1969, during the wage and price controls that existed in the economic stagnation of the US from 1970-1982, the development of the market for corporate 
control in the period 1983-1992, the stock option explosion of 1992-2001, the accounting and backdating scandals of 2001-2007, pay restrictions imposed during Treasury's troubled asset relief program (TARP) recipients during 2008-2009 and the Dodd-Frank Executive Compensation Reform Act from 2010-2011. Murphy (2013) provides several instances of (i) knee-jerk regulatory intervention to isolated perceived abuses in pay having adverse unintended consequences and (ii) reactions to situations where CEOs are perceived to be getting richer while lower-level workers suffer, giving rise to increased disclosure rules, limits on CEO pay tax deductibility and the wide-ranging pay regulations of the 2010 Dodd-Frank Act. Murphy notes (p. 249) that "the demands to reform (or punish) CEO pay are concentrated in 'third parties' angry with perceived levels of excessive pay, and not shareholders concerned about insufficient links between pay and performance". Murphy (2011, abstract) summarizes the legal history of CEO pay regulation in the US as follows "Over the past 80 years, Congress has imposed tax policies, accounting rules, disclosure requirements, direct legislation, and myriad other rules to regulate executive pay. With few exceptions, the regulations have generally been either ineffective or counterproductive, typically increasing (rather than reducing) CEO pay and leading to a host of unintended consequences, including the explosion in perquisites in the 1970s, golden parachute plans in the 1980s, stock options in the 1990s, and restricted stock in the 2000s".

\section{$2.4 \quad$ Legal Perspective}

Australian regulations in relation to employment of executives in the private sector are contained primarily in the Fair Work Act 2009 and the Corporations Act 2001, though statutes in relation to discrimination, privacy and misleading and deceptive conduct are also of relevance. These legal issues are canvassed in a publication by Clayton Utz (2012). The Corporations Act 2001 (Cth) requires that a company director or other officer exercise their powers and discharge their duties with care and diligence [s 180]. This duty is subject to a business judgment rule that requires a director making a business judgment to:

- make the judgment in good faith and for a proper purpose;

- not to have a material personal interest in the subject matter of the judgment;

- inform themselves about the subject matter of the judgment to the extent they reasonably believe to be appropriate;

- rationally believe that the judgment is in the best interests of the corporation. 
In addition, directors and other officers of companies must exercise their powers and discharge their duties in good faith in the best interests of the corporation and for a proper purpose [s 181]. They are prohibited from improperly using their position to gain an advantage for themselves or someone else or to cause detriment to the corporation [s 182] and are prohibited from using information obtained as a consequence of their role with the company to gain an advantage for themselves or someone else or to cause detriment to the corporation [s 183]. These last two provisions also apply to employees of the company.

The Corporations Act 2001 also (recently) restricts giving benefits greater than one year's base salary on retirement from a board or managerial office, unless shareholders approve the benefit. ${ }^{7}$ These restrictions cover anyone who has been a director of a company at any time during the three previous years and, for listed companies, key members of management and / or the five highest paid executives over the prior 12-month period. ASX Listing Rules in relation to termination payments also apply to companies listed on the exchange. Specifically, a listed company is obliged to ensure that no officer will be entitled to a termination benefit if a change occurs in the shareholding control of the company (Listing rule 10.18) unless such termination payments are agreed to by shareholders at a general meeting (Listing rule 10.19).

In essence the legal view is inconsistent with agency-based arguments. Agency arguments are based on an assumption that executives will act in their own interests, though the parties they contract with are aware of these incentives and incorporate bonding and monitoring arrangements to control the potential conflict. The legal view however states that executives must not act in their own interests and must put the interests of the corporation first.

\section{GLOBAL TRENDS IN EXECUTIVE COMPENSATION}

\subsection{US Evidence}

While there are many other papers that describe executive compensation for US executives, we draw on the recent monograph-length paper by Murphy (2013) to provide graphical representations of the current and historical levels of payment to US CEOs in S\&P 500 firms. Few would doubt the seminal and on-going contributions that Kevin Murphy has made to the development of executive

\footnotetext{
${ }^{7}$ Retirement is broadly defined to include loss of office and resignation.
} 
remuneration, and hence a reliance on his recent work to 'paint the picture' for the US is warranted. Figure 2.1 (reproduced with Kevin Murphy's permission from Murphy, 2013) below shows mean and median 2011 pay for CEOs of 465 S\&P 500 corporations. Several key statistics are worthy of note:

- Average total compensation is estimated at $\$ 11.6$ million (based on grant date valuations) or $\$ 12.3$ million, based on realized pay. Median compensations, reflecting the considerable skew in executive compensation, are $\$ 9.6$ and $\$ 7.8$ million respectively.

- The biggest component of executive compensation is associated with stock awards (both restricted stock and performance shares). Stock awards now comprise between 31 per cent and 34 per cent of total mean and median compensation for US CEOs.

- Base salary is between 14 per cent and 18 per cent of mean total compensation, and 11 per cent to 13 per cent of median total compensation.

- Stock options comprise 18 per cent or 19 per cent of mean total compensation, while options grants represent 16 per cent of median grant-date total compensation.

- Non-equity incentive payments, which represent payouts during the current year for the current year and prior year awards, range between 18 per cent and 24 per cent of mean total compensation, and 15 per cent to 20 per cent of median total compensation. 
Figure 2.1 2010 pay for CEOs in S\&P 500 companies

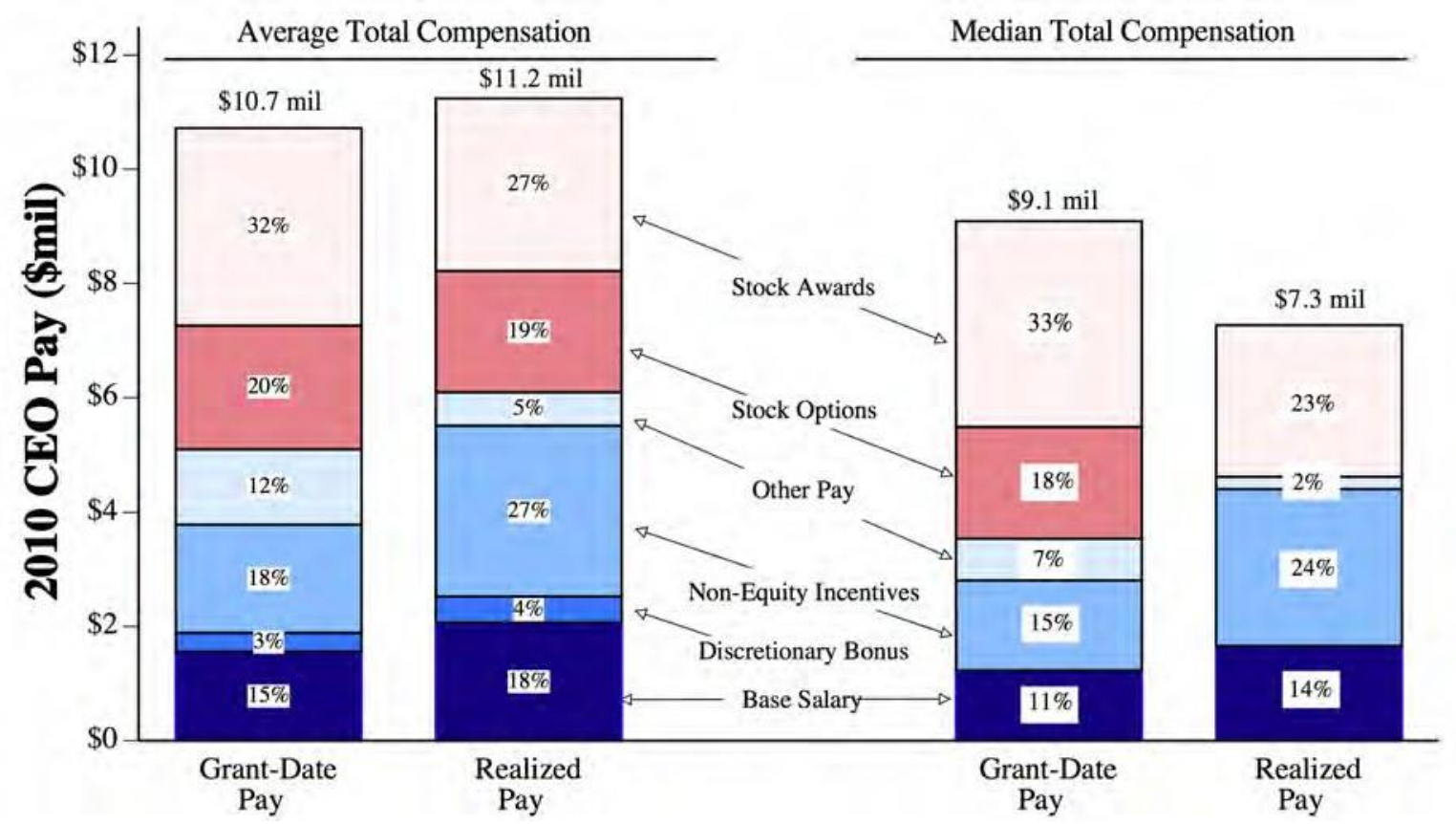

Note: Figure 2.1 is based on proxy statement information compiled in Standard \& Poors' ExecuComp database for 498 S\&P 500 firms with fiscal closings between June 2010 and May 2011, based on ExecuComp's November 2011 update .

Grant-date Pay:

Base Salary and Discretionary Bonus reflects amounts actually received for the fiscal year

Non-Equity Incentives evaluated at target level (or average of minimum and maximum if target not reported) Stock Options evaluated at grant date using firm-estimated present value (typically BlackScholes (1973) calculations)

Stock Awards evaluated at grant-date using firm-estimated present value (typically grant-date market price), including both time-lapse restricted stock and performance shares.

Other Compensation includes perquisites, signing bonuses, termination payments, above-market interest paid on deferred compensation, and the change in the actuarial value of pension benefits.

Realized Pay:

Base Salary and Discretionary Bonus reflects amounts actually received for the fiscal year

Non-Equity Incentives defined as payouts during the fiscal year (including payouts on awards made in prior years) Stock Options defined as gains executive realized by exercising options during the fiscal year

Stock Awards defined as value of awards vesting during the fiscal year (valued on the date of vesting)

Other Compensation includes perquisites, signing bonuses, termination payments, above-market interest paid on deferred compensation, and pension benefits paid during the year.

The pay-composition percentages for Average Compensation are calculated as the average ratio of each component to total compensation for each CEO. The composition percentages for Median Compensation are calculated as the median ratio of each component: median ratios do not sum to $100 \%$ (because the sum of the medians is not the median of the sum). 
Figure 2.3 from Murphy (2013) (reproduced with permission) shows average total executive compensation for S\&P 500 firms for the period 1970 to 2011 (expressed in 2011 purchasing power) and its division into equity and non-equity components. Several things are worthy of note, in particular:

- Total pay increased from around $\$ 1.1$ million in 1970 to $\$ 10.9$ million in 2011 , down from a peak of $\$ 18.2$ million in 2000 . Thus over this 42 year period CEO pay for S\&P 500 firms outstripped inflation by a factor of approximately 10 .

- Non-equity pay, which includes base salaries, payouts from short-term and long-term bonus plans, deferred compensation and other benefits, increased from around \$1.1 million in 1970 to approximately $\$ 4.1$ million in 2011 . Thus non-equity pay increases outstripped CPI adjustments by a factor of approximately four.

- The growth in equity-linked pay, which includes the grant date values of stock options and restricted stock, is far more dramatic. In the period 1970 to 1978 total pay is almost entirely comprised of non-equity pay. However, by 2011 equity pay averages around \$6.8 million.

- While it is not claimed to be causal, it is interesting to note that just a few years after Jensen and Meckling's (1976) paper on agency theory, the switch toward the use of equity pay as part of CEO compensation starts to emerge. By 1998 equity pay became the majority part of total executive compensation, and this is maintained in each year through to 2011.

- However, as noted by Kaplan (2013, p. 9), while CEOs "earn a great deal, they are not unique. Other groups with similar backgrounds - private company executives, corporate lawyers, hedge fund investors, private equity investors and others - have seen significant pay increases where there is a competitive market for talent and managerial power problems are absent." 
Figure 2.3 Average Equity and Non-equity Grant-Date Pay for CEOs in S\&P 500 Firms, 1970-2010

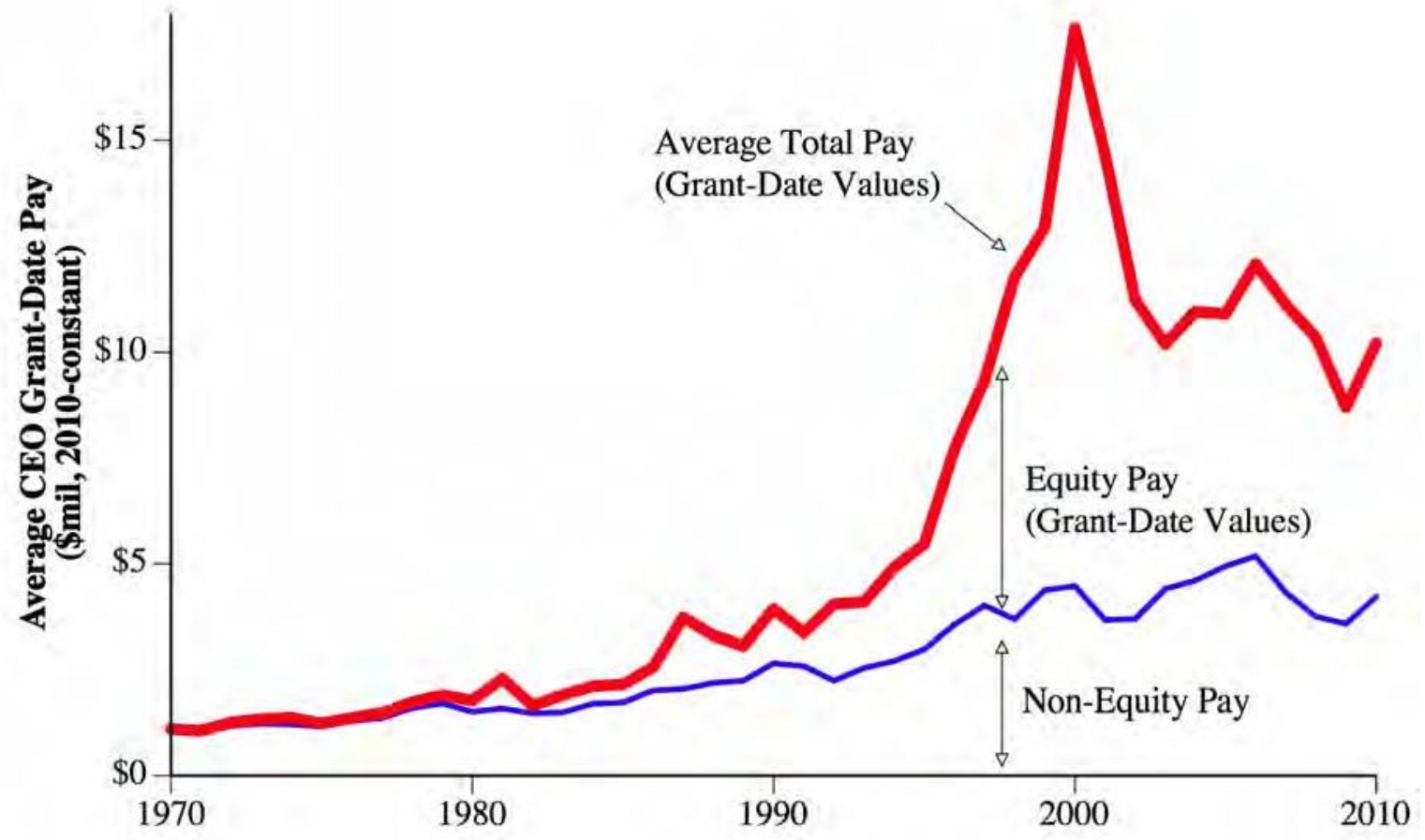

Note: Compensation data are based on all CEOs included in the S\&P 500, using data from Forbes and ExecuComp. CEO total pay includes cash pay, restricted stock, payouts from long-term pay programs and the value of stock options granted (using company fair-market valuations, when available, and otherwise using ExecuComp's modified Black- Scholes approach). Average (median) equity compensation prior to 1978 estimated based on option compensation in 73 large manufacturing firms (based on Murphy (1985)), equity compensation from 1979 through 1991 estimated as amounts realized from exercising stock options during the year, rather than grant-date values. Non-equity incentive pay is based on actual payouts rather than targets, since target payouts were not available prior to 2006. Dollar amounts are converted to 2010-constant dollars using the Consumer Price Index.

Figure 2.4 below is also reproduced from Murphy (2013), again with permission. It highlights important trends in both the composition and level of median grant-date pay for CEOs over the years 1992-2011. Of note are the following points:

- Median total pay in Figure 2.4 in each year is significantly below mean pay in Figure 2.3, reflecting the skewness in pay distributions for US CEOs.

- Much of the growth in median total pay between 1992 and 2011 is due to an escalation in stock-option compensation between 1993-2001 coupled with a dramatic shift away from stock option grants towards restricted stock from between 2002 and 2011. 
- In 1992 base salaries are about 41 per cent of the \$2.9 million median total CEO compensation package, while stock options accounted for about 25 per cent. By 2001, base salaries are only about 18 per cent of the median pay package, while options are more than 50 per cent.

- In 2011 more than two-thirds of median total pay is in the form of equity-based compensation.

Figure 2.4 Median Grant-date Compensation for CEOs in S\&P 500 Firms, 1992-2010

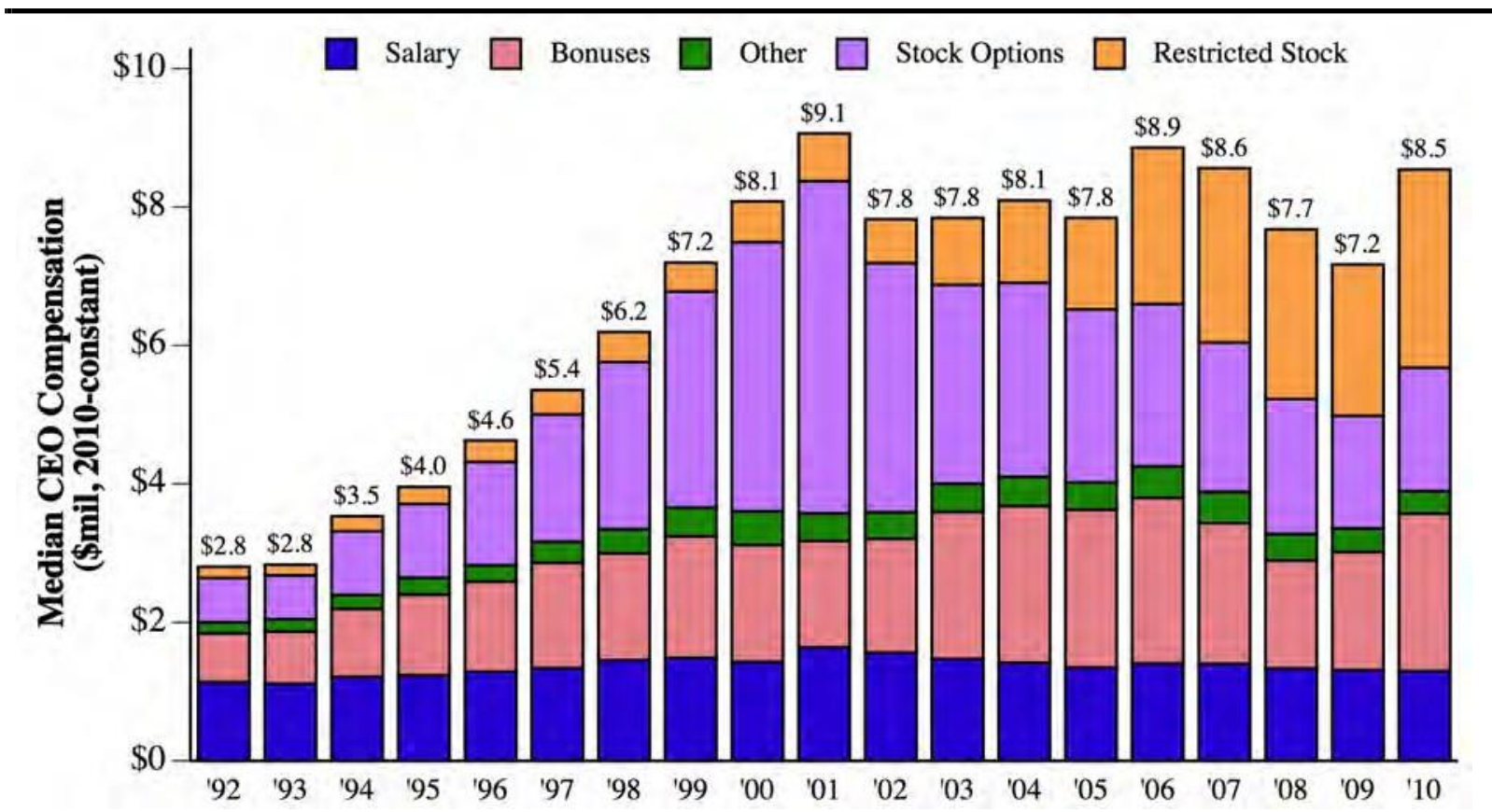

Note: Compensation data are based on all CEOs included in the S\&P 500, using data from ExecuComp. CEO grant-date pay includes cash pay, payouts from long-term pay programs, and the grant-date value of stock and option a wards (using company fair-market valuations, when available, and otherwise using ExecuComp's modified Black-Scholes approach). Monetary amounts are converted to 2010-constant US dollars using the Consumer Price Index.

\subsection{International CEO Pay Trends}

Having reviewed growth in CEO payments in the US, the question of whether US executives are paid more than their international counterparts somewhat naturally arises. This issue is taken up in a recent paper by Fernandes et al (2013). The paper argues, contrary to widely accepted views in the executive compensation literature that US CEOs are paid significantly more than those in other nations (see Murphy, 1999 and Bebchuk et al., 2002 for example), that the US pay "premium is economically modest and primarily reflects performance-based pay demanded by institutional shareholders and independent 
boards" (Fernandes et al. 2013, Abstract, p. 323). International comparisons of CEO pay are difficult because regulations in relation to pay disclosures are different. An exception is however the UK where CEO pay disclosures have been mandated since 1995. While Conyon and Murphy (2000) show that US CEOs earn almost twice UK CEOs in 1997 (after controlling for industry, firm size and a variety of firm and individual characteristics), Conyon et al. (2011) show that the pay premium of US to UK CEOs had fallen to 40 per cent by 2003 , and this premium can be further reduced after adjusting for the risk inherent in undiversified CEO equity portfolios. Fernandes et al. (2013) use data from 14 countries that required detailed CEO pay disclosures by 2006 . Their sample of 1,648 US and 1,615 non-US firms (with revenues greater than \$US1 billion) comprise nearly 90 per cent of the 2006 market capitalization of publicly listed firms in these countries. They show that US CEOs earn an average of 26 per cent more than their foreign equivalents in 2006, far lower than that documented in prior academic research. Their experiment controls for ownership and board structure (US firms tend to have higher institutional ownership and more independent boards) in addition to the usual firm-specific attributes (size, industry, stock price volatility and performance and growth opportunities) and CEO characteristics (age, tenure, education and past experience). Figure 1 and 2 from Fernandes et al. (2013) provide the main features of their findings, which can be summarized as:

- When controls for only firm size and industry are considered, US CEOs earn substantially more than non-US CEOs. When additional controls for other firm characteristics, ownership, and board characteristics are included, US CEOs have effective parity in pay levels with other Anglo-Saxon nations (UK, Ireland, Australia and Canada) as well as Germany, Italy and Switzerland.

- When the results after risk adjustment using the Hall and Murphy (2002) approach are considered, again with controls for only firm size and industry, the US estimated pay using the 'certainty equivalence' approach is $\$ 2.1$ million, and this is statistically higher than the non-US pay of $\$ 1.46$ million. When additional controls are introduced the results show that US CEO pay is significantly less than in the UK and Australia, and insignificantly different to CEO pay in Canada, Italy, Ireland and Switzerland.

\subsection{Australian CEO Pay}


We used the Sirca Limited Corporate Governance database to produce mean and median pay levels for Australian listed firms for the years 2001-2012, as well as the average over all years. The results, which are expressed in December 2012 purchasing power units, are in Tables 1 - 6 and Figures 1 - 6 below. Table 1 covers all firms in the database, a total of 11,281 firm years or an average of 940 firms per year. Table 2 relates to the top 100 firms by market capitalization each year, while Table 3 and 4 cover the top 200 and top 300 firms respectively. Table 5 relates to medium sized Australian firms, represented by firms in the top 101-300 by market capitalization. Finally, Table 6 covers small listed firms, defined as all firms in the database other than the top 300. A corresponding figure is provided for each of these tables. At this stage we have not attempted to control for firm characteristics nor have we attempted to investigate pay-performance relationships. The Sirca corporate governance database captures companies that represent well over 95 per cent of total ASX market capitalization. The following points summarize the main descriptive statistics in Tables 1 - 6 and Figures 1 - 6.

- Mean (median) total compensation for all companies in Table 1 grew from \$0.714 million to $\$ 1.210$ (\$0.355 million to \$0.644 million) million between 2001 and 2012. Thus CEO pay has grown faster than the Australian CPI. There is a clear pattern of higher pay for the larger companies. The mean (median) average total compensation over the 12 years are as follows:

○ Top 100 firms (large firms in Table 2) $\$ 4.180$ million and $\$ 3.080$ million

○ Top 200 firms (Table 3) \$2.916 million and \$1.818 million

○ Top 300 firms (Table 4) \$2.282 million and \$1.281 million

○ Top 101-300 firms (medium size firms in Table 5) \$1.333 million and \$0.927 million, and

○ Firms ranked 301 and higher (small firms in Table 6) \$0.460 million and \$0.341 million.

- Equity based compensation for all firms in Table 1 is 20.2 per cent of mean total compensation and 12.2 per cent of median total compensation over all sample years 20012012. Again there is a very clear pattern in relation to firm size, with the proportion of total compensation paid in the form of equity rising as firm size increases. The mean and median proportions of equity compensation to total compensation are as follows from Tables 2 to 6 :

- The largest firms (top 100) - mean proportion 23.0 per cent, median 23.4 per cent

- The largest 200 firms - mean proportion 21.5 per cent, median 18.1 per cent 
- The largest 300 firms - mean proportion 21.4 per cent, median 20.0 per cent

○ Medium sized firms (top 101-300) - mean proportion 18.9 per cent, median 16.9 per cent

- Small firms (301 and up) - mean proportion 17.4 percent, median 10.0 per cent

Thus the equity component of Australian CEO compensation is much lower than in the US, where the equity-based component of total compensation has exceeded 50 per cent in each of the years from 1998.

- There is a clear trend upward in the use of equity based compensation, with mean (median) proportions in Table 1 for all firms in 2001 being 8.6 per cent ( 3.9 per cent), with these rising to 25.1 (17.2) per cent by 2012, respectively. This growth in the use of equity based compensation is more pronounced in the larger firms than for smaller firms. Specifically Table 2 to 6 show that between 2001 and 2012 equity forms of compensation as a proportion of total compensation has increased as follows:

- Table 2 (the largest firms) the growth is from 9.1 per cent to 30.4 per cent

- Table 3 (top 200 firms) the growth is from 10.5 per cent to 27.0 per cent

- Table 4 (top 300 firms) the growth is from 9.8 per cent to 26.1 per cent

- Table 5 (medium sized firms) the growth is from 10.7 per cent to 19.5 per cent, and

- Table 6 (small firms) the growth in equity based compensation as a proportion of total compensation between 2001 and 2012 is from 5.8 per cent to 23.2 per cent. These proportions are however somewhat misleading because the average equity based payment in 2001 to small firms is only $\$ 19,226$ per firm, and this rose to $\$ 157,936$ per firm by 2012 . Among the top 100 firms equity based compensation dwarfs these values with mean equity based compensation rising from an average of $\$ 234,287$ in 2001 to $\$ 1,139,360$ by 2012 .

- Yearly growth figures show that mean and median CEO compensation for all firms in Table 1 grew quite strongly from 2001-2007, but the GFC has stopped this trend, resulting in mean CEO compensation in 2012 at approximately the same level as in 2007. Median CEO pay has however continued to show modest growth from 2007 to 2012. The levels of pay for the top 100 firms have however declined quite dramatically between 2007 (where the average total compensation for a CEO of a top 100 firm was $\$ 5.890$ million) and 2012 (where the average pay was $\$ 3.744$ million). On average a top 100 CEO in Australia is about $\$ 2$ million worse off 
in 2012 than he / she was in 2007. Among the top 200 firms the drop in average pay between 2007 and 2012 is $\$ 1.378$ million, for the top 300 firms it is $\$ 0.985$ million and for medium size firms the average CEO salary drop by $\$ 0.404$ million. Small firm CEO total compensation bucks this trend, rising from \$0.518 million in 2007 to \$0.680 million in 2012.

- Irrespective of the groupings we form however, Australian CEO total compensation (both means and medians) have outstripped the CPI over the 12 years we summarize. These trends are clearly evident in each of the figures we provide. The increase is largely attributable to equity compensation in each group. For example, equity compensation in top 100 firms rises by $\$ 905,073$ meaning that top 100 firms' total compensation outstrips inflation by almost one million dollars.

\section{EMPIRICAL EVIDENCE ON EXECUTIVE COMPENSATION}

There is an extensive literature on CEO compensation with a particular focus on US public firms (see for example review articles by Frydman and Jenter, 2010, Murphy, 1999 and 2013, Jensen and Murphy, 2004, Kaplan, 2013, Ferrarini et al., 2009). We do not intend to fully canvass this voluminous work. Rather we attempt to draw out broad trends that emerge from review papers that involve time series and cross sectional examinations, and then provide a comprehensive review on the Australian-based evidence.

\subsection{The increase in CEO compensation}

The dramatic increase in CEO compensation of US publicly traded corporations over the past three decades has attracted extensive attention in academic research. Most studies rely on either the efficient contracting theories or managerial power theories in an attempt to explain the increase. However, as argued by Murphy (2013), any compelling theory must not only explain the increased level of CEO pay, but should also explain the explosion in option grants to lower-level executives and employees, the leveling of CEO pay after 2001 and the emerging dominance of restricted stock in the early 2000 s.

In the efficient-contracting camp, several general equilibrium models are recently developed by accommodating the shift in the relative importance of general 'managerial capital' or the marginal product of managerial ability as a function of firm size. One important change in the CEO labour market over the past several decades is the increased prevalence of newly appointed CEOs being hired externally, jumping from $15 \%$ in the 1970s to nearly one-third in the late 1990s (Murphy and Zabojnik, 2008). Murphy and Zabojnik (2008) and Frydman (2007) therefore argue that the nature of the CEO job 
market has changed gradually over recent years and that the demand for CEOs has shifted away from firm-specific capital (reflecting skills, knowledge and experience valuable only within the organization) towards more general managerial skills. Both papers offer general equilibrium models and attribute the increase in CEO wages to the increased prevalence of outside hiring and the intensified competition among firms for managerial talent. The above argument is further supported by the comparable rise in pay for top talent in other sectors with active and mobile labour markets such as athletes, lawyers, investment bankers and hedge fund managers during the same sample period (Kaplan and Ruah, 2010).

On other hand, Gabaix and Landier (2008) build an equilibrium model and argue that in equilibrium the most skilled CEOs should be employed by the largest companies, as managerial talent has greatest effect in bigger firms. Accordingly, any shift in the size distribution of firms will lead to a proportional change in CEO pay. They show that the dramatic rise in US CEO pay since 1980 can be fully explained by the simultaneous growth in firm size.

However, as Murphy (2013) argues, while the efficient-contracting theories provide important insights on the rise in CEO pay, they cannot explain why stock options were once the preferred form of equity incentives, and why this shifted to restricted stock after 2001. More importantly, the extensive option grants to employees well below the executive suite are also contradictory with efficient contracting theories.

Compared to the efficient-contracting camp, the managerial power hypothesis is even less successful in explaining the increase in CEO pay. Under this hypothesis, CEOs in firms with weak corporate governance and acquiescent boards are able to (at least partly) determine their compensation, resulting in inefficiently high levels of compensation. This argument is inconsistent with improved board independence in US firms during the 1990s, as evidenced by the increasingly higher percentage of outside directors serving on the board and the CEO being the sole insider in about half of all firms (Murphy, 2013). In fact, it is well cited that most aspects of the corporate governance in US firms have improved since the 1970s, which in turn largely alleviates the influence of CEOs over board members (Holmstrom and Kaplan, 2001).

In attempting to offer a managerial-power explanation, Bebchuk and Grinstein (2005) argue that the 'outrage constraint' on managerial power largely depends on stock market conditions and sentiment. The stock market boom in the 1990s weakened outrage and led to a dramatic increase in CEO pay over that decade. Conversely, outrage strengthened in the bearish market during 2000-2002, 
resulting in the reduction in CEO pay and the use of stock options. However, as Murphy (2013) argues, a fundamental problem with the managerial-power hypothesis as well as the Bebchuk and Grinstein (2005) explanation is that 'there is no principled way to refute any trend in pay given the authors' flexible (and unmeasurable) definition of both the 'outrage constraint' and its importance' (Murphy, 2013, p. 334).

Besides the efficient-contracting and managerial power theories, recent research also offers several explanations, with some success, to understand the increase in CEO pay from other perspectives such as perceived costs of options, disclosure requirements, tax policies and non-market mechanisms. Hall and Murphy (2002) argue that the greater use of stock options in the 1990s reflects the fact that many directors and top executives perceived options to be costless and did not understand their true economic cost for shareholders. The SEC disclosure rules in place during that period and the pre-2003 NYSE listing requirement also contributed to the 'perceived cost' problem, as the costs of options to be granted were are not required to be disclosed or approved by shareholders. The perceived cost view may also explain the decreased use of options since 2002, as many firms voluntarily expensed options since early 2003 under FAS 123R which was mandated in 2006 (Murphy, 2013). In addition, Rose and Wolfram (2002) claim that the tax laws enacted in 1994 effectively made stock options less expensive than cash pay, and thus partly contributed to the explosion in stock options.

Piketty and Saez $(2003,2006)$ propose an explanation based on non-market mechanisms such as social norms or labour market institutions. They document evidence of a U-shape pattern over the course of the twentieth century for the pay of those at the very top of the income distribution. They therefore argue that the shift in social norms towards the acceptability of extreme pay since the 1970s contributed to the increase in CEO compensation.

Most empirical studies on CEO compensation limit their samples to the post-1990 period, when the Execucomp data are readily available for US firms. Frydman and Saks (2010), however, offer a unique long-term perspective by hand-collecting and examining CEO pay in top 100 (in terms of sales) US firms over the period of 1936-2005. In line with Piketty and Saez (2003, 2006), Frydman and Jenter (2010) show that CEO compensation between the end of World War II and before the mid-1970s is characterized by low levels of pay, little dispersion across top managers, moderate pay-performance sensitivities, and a weak relation between pay and firm size. From the mid-1970s to the early 2000s, compensation levels grew dramatically, differences in pay among CEOs widened, and equity incentives 
tied managers' wealth closer to firm performance and firm size. The long-term perspective presented in Frydman and Saks (2010) therefore reveals that the recent theoretical advances fail to explain the trend in CEO pay in the pre-1970 period.

\subsection{CEO incentives and pay-performance sensitivity}

Equity-based compensation is used to align the interests of shareholders and managers (Jensen and Meckling, 1976) because decisions that increase shareholders' wealth also increase managers' wealth. To measure CEO incentives, pay-performance sensitivity is often utilized which indicates how much compensation depends on how well the company performs. Jensen and Murphy (1990) conceptualize pay-performance sensitivity as the dollar change in executive wealth associated with each dollar change in shareholder wealth. They document that for between 1974 and 1986 the average CEO experiences a change in wealth of $\$ 3.25$ for each $\$ 1,000$ change in firm value, and the pay-performance sensitivity decreases in firm size. The results therefore indicate that CEO incentives are low on average, particularly in large firms.

The insensitivity of CEO wealth to performance documented in Jensen and Murphy (1990) is questioned by subsequent research, and alternative measures of pay-performance sensitivity are proposed (see Hall and Liebman, 1998; Aggarwal and Samwick, 1999; Edmans et al., 2009). For example, Hall and Liebman (1998) argue that the dollar changes in CEO wealth due to typical changes in firm value are in fact not small. They measure CEO incentives as the dollar change in CEO wealth for a percentage change in firm value. Murphy (1985) and Kaplan (1994) recommend the use of the elasticity of CEO wealth to shareholder value, which indicates the percentage change in CEO wealth for a percentage change in firm value. Edmans et al. (2009) and Frydman and Jenter (2010) discuss the advantages and disadvantages of different incentive measures. They suggest that they are all important and should be considered independently due to the heterogeneity of corporate activities CEOs engage in and CEO utility. ${ }^{8}$

Overall, research on US firms suggests that the pay-performance sensitivity of CEO's wealth surged during the 1990s, mostly due to use of executive options (Frydman and Jenter, 2010). Between 1990

\footnotetext{
${ }^{8}$ For example, the Jensen-Murphy statistic is the right measure for corporate actions whose dollar effect is not dependent on the size of the firm, such as overpaying for a takeover. The incentive measure suggested by Hall and Liebman (1998) is appropriate for activities whose impact scales with firm size (e.g., a corporate restructure). The elasticity measure is the right one when the effort choice of the CEO has a multiplicative impact on both firm value and CEO utility.
} 
and 2011, CEOs are rewarded for good performance, and penalized for poor performance (Kaplan, 2013). However, the fractional ownership of most US CEOs in the firms they manage remains low, and it is even lower today than it was in the 1930s (Frydman and Jenter, 2010).

\subsection{CEO pay, firm performance and corporate actions}

The issue of whether CEO incentives affect firm performance has been quite controversial, and there is no theoretical and empirical consensus in the literature. In a seminal study, Morck et al. (1988) document a nonlinear cross-sectional relation between managerial ownership and firm valuation. They find that firm performance is increasing in managerial ownership for ownership lower than $5 \%$ or greater than 25\%, but decreases in ownership between 5\% and 25\%. While the results in Morck et al. (1988) imply that greater CEO incentives are not always better-aligned and tend to be worse in the $5 \%$ to $25 \%$ ownership range, subsequent studies present mixed evidence on the effect of different aspects of CEO equity incentives on firm performance (see McConnell and Servaes, 1990; Mehran, 1995; Habib and Ljungqvist, 2005).

In contrast, Demsetz and Lehn (1985) and Himmelberg et al. (1999) argue that observed levels of managerial ownership represents an equilibrium solution to agency problems. As the complex process of compensation arrangements involves the CEO, the compensation committee and consultants, the boards and the external labour market of executives, the level of compensation and incentives is / are determined by a large number of observable and unobservable firm and CEO characteristics. Therefore, the cross-sectional relation between managerial ownership and firm value is spurious. To control for the alleged endogeneity problem, studies by Demsetz and Lehn (1985), Loderer and Martin (1997), Cho (1998), Himmelberg et al. (1999), Palia (2001) and Villalonga and Amit (2006) either utilize simultaneous equations models or employ instrumental variables so as to identify the causal effects of managerial incentives on firm value. In addition, Coles et al. (2012) estimate a structural model and show that the documented hump-shaped relation between managerial ownership and firm value (McConnell and Servaes, 1990) is the outcome of firms having different productivity from physical assets and managerial inputs. To assess the effectiveness of standard econometric approaches to the well-known endogeneity problem, they conclude that fixed effects and instrumental variables do not generally provide reliable solutions to simultaneity bias in testing the effect of managerial ownership on firm performance.

Given the difficulty of convincingly identifying the causal effects of managerial incentives on firm value, recent research endeavors to connect executive incentives to a wide variety of corporate 
decisions and outcomes. The idea behind this is that incentives influence the decisions managers make which in turn impact firm value. For example, Core and Larcker (2002) examine a sample of firms adopting 'target ownership plans' and find that the required increases in managerial ownership lead to improvements in the firm's operating performance. Fenn and Liang (2001) and Brown et al. (2007) find that executives with higher ownership are more likely to increase dividends, but Fenn and Liang (2001) also show that management stock options are negatively (positively) related to dividends (repurchases). Denis et al. (1997) suggest that managerial ownership creates incentives for managers to pursue valueincreasing investments and therefore constrains business diversification and avoids value destruction.

With respect to managerial risk-taking, recent studies recognize the differential theoretical predictions regarding the relationship between firm risk and the sensitivity of executives' wealth to firm risk (vega) and to changes in stock price (delta). Coles et al. (2006) and Low (2009) document a positive relationship between vega and firm risk, but provide mixed evidence for delta. Evidence on CEO pay and takeovers is also mixed. Consistent with efficient contracting, Datta et al. (2001) document a strong positive relation between acquiring managers' equity-based compensation and merger performance. In contrast, Harford and Li (2007) compare compensation policies implemented in firms that undertake either acquisitions or capital expenditures (external vs. internal investment). Consistent with managerial power explanations, Harford and Li (2007) find that CEOs are financially better off from making acquisition decisions, even though these decisions typically destroy shareholder value (see also Bliss and Rosen, 2001).

Overall, there is ample but often mixed evidence between CEO incentives and a variety of corporate policies and actions. While one may interpret this evidence as empirical validity of the widespread misuse of CEO compensation, an alternative is that the endogeneity of compensation arrangements makes it extremely difficult to interpret any observed relation between CEO compensation and corporate outcomes as evidence of a causal effect. A response to such a challenge in recent research is to identify a natural experiment such as a regulatory change and unexpected 'shock' to the economy (see for example, Brown et al., 2007 and Gormley et al., 2014).

\subsection{Australian Evidence}

4.4.1 The level of CEO pay and its determinants

Early research (before 1999) on Australian CEO compensation typically examines the association between the level of CEO cash-based compensation and firm size and performance. This is largely due to 
disclosure requirements in Australia before 1998, when information about component parts of remuneration is absent and unavailable for research. In addition, early research tends to rely on a small sample of Australian firms and/or a relatively short sample period, which makes the hand-collection of CEO compensation data from annual reports feasible and cost-effective. In fact, the sample size in these studies tends to be typically less than 100, with the only exception being Merhebi et al. (2006) ${ }^{9}$. Although early research on Australian CEO pay generally documents a positive association between the level of CEO cash-based compensation and firm size, it typically reports that cash-based compensation and its components are not significantly associated with prior-year or current-year firm performance measured by either accounting return (such as ROA or ROE) or stock return of the firm.

For example, Izan et al. (1998) examine the relation between cash-based compensation, accounting and share price performance, and firm size for a sample of 99 Australian firms with available financial and price data from 1987 to 1992 . They find no evidence of a linkage between CEO cash pay and current period performance, as well as prior-year performance. They discuss several alternative explanations and conclude that Australian CEOs have had, at least compared to US CEOs, a relatively small proportion of total (cash) compensation 'at risk'. O'Neil and lob (1999) examine 49 large Australian firms in 1997. They find that the level of CEO base salary and aggregate pay is positively related to firm size, but there is no significant relation between CEO pay and firm performance, CEO age and the number of CEO service years.

Merhebi et al. (2006) conduct a large sample study on CEO cash pay for the Top 500 Australian public firms (based on reported profits) for the period 1990-1999. ${ }^{10}$ They find that (i) CEO pay is statistically positively related to firm size (CEO pay increases by 2.74 per cent for a 10 per cent increase in firm size, measured as revenue); and (ii) CEO pay is insignificantly related to contemporaneous measures of performance (return on assets, return on equity and share price performance).

Two exceptions in early research are Matolcsy (2000) and Holland et al. (2001), which report either mixed or weak evidence on the relationship between CEO cash pay and firm performance. Holland et al. (2001) examine a sample of 26 Australian companies over 1989-1999, and find a weak positive relationship between CEO compensation and current period market performance (no statistics are

\footnotetext{
${ }^{9}$ This is partly because machine-readable databases that include information about executive compensation have not been commercially available until recently.

${ }^{10}$ The data disclosed at the time of the Merhebi et al. (2006) study do not provide details on equity-based compensation.
} 
presented). Matolcsy (2000) tests how business cycles affect the association between changes in CEO pay and changes firm performance. Using a sample of 100 randomly selected Australian firms over 1987-1995, Matolcsy first shows that, on average, CEO cash-based compensation increased by $13.24 \%$ over the sample period. The average growth rate is higher during periods of 'Steady growth' (15\%) and 'Soft landing' (24\%), and lower for periods of 'Flat recovery' (9\%) and 'Recession' (11\%). The results show that the relationship between changes in CEO cash compensation and changes in financial performance is positive during economic growth, but is flat during an economic downturn.

Australian regulations and disclosure requirements in relation to executive and director pay were amended by the Company Law Review Act 1998 (CLRA) as part of the Corporate Law Economic Reform Program (CLERP). The CLRA amended provisions of the Corporations Law deal with financial reporting and auditing for accounting periods ending on or after 1 July 1998. Since then, Australian public companies are required, in their directors' report, to provide detailed information and discussions on the nature, amount and rationale of each element of the compensation paid to senior executives and board directors, including equity-based compensation. The regulation was further amended in 2004, including the issuance of an accounting standard (AASB1046 Director and Executive Disclosures by Disclosing Entities) prescribing detailed disclosure of executive and director remuneration components, and the CLERP (Audit Reform and Corporate Disclosure) Act 2004 (CLERP9) introducing a number of amendments in relation to executive compensation.

Following the introduction of increased disclosure regulations that came into effect on 1 July 1998, Matolcsy and Wright (2007) provide descriptive evidence on the structure of Australian CEO pay for the period of 1999-2001. Using firms in the Top 500 with available data, they find 238 firm-years (34\%) where only cash is paid to the CEO and 458 firm-years (66\%) where a combination of cash- and equitybased compensation is paid. CEO compensation is highest in the cash and equity-based compensation group of the banking and finance sector where the mean (median) compensation for the equity-based group is $\$ 1.865$ million ( $\$ 1.153$ million). These pay levels are however much lower than in the US where Murphy (1999) reports median CEO compensation of \$US4.582 million for 1996.

Jeff and Taylor (2002) present the first Australian examination on executive stock options for a sample of 258 Australian firms in 2000. They find that large firms with better prior-year market performance are more likely to grant stock options to their CEOs. The percentage of stock options over total compensation is positively associated with firm size and prior-year stock return, but negatively 
related to current-year accounting performance (ROA), CEO ownership and insider ownership. They conclude that the results are more consistent with the notion that firms with weak corporate governance are likely to use stock options excessively.

As information about equity-based compensation became more publicly available, recent research re-examines the association between firm performance and CEO pay, using total compensation as well as its four different components (i.e., salary, bonus, shares and options). Evidence suggests that the level of CEO compensation is positively related to current-year ROA (Schultz et al., 2013), changes in ROE (Lee, 2009), current-year stock return (Matolcsy and Wright, 2006) as well as past-year accounting performance (Chalmers et al., 2006; Doucouliagos et al., 2007). For example, Doucouliagos et al. (2007) explore the relationship between CEO pay and performance in 10 Australian banks during 1992-2005. They find that CEO pay is positively related to firm size, prior-year bank performance, prior-year stock return and institutional ownership, but negatively associated with board size.

However, evidence on CEO pay and firm performance is somewhat inconclusive. A number of studies, particularly those examining CEO pay in one particular year or over a short sample period, report an insignificant association between CEO pay and firm performance (Capezio et al., 2011; Cybinski and Windsor, 2013; Heaney et al., 2010; Walker, 2010). Walker (2010) randomly selected 50 'high-growth' and 50 'low-growth' Australian firms. She found that performance-based pay is positively related to firm size and growth, but it is not significantly associated with current-year ROA, CEO ownership and CEO duality. Heaney et al. (2010) analyze 1,144 listed Australian firms in 2006, following the adoption of International Financial Reporting Standards (IFRS) that resulted in more detailed disclosure on executive compensation. They find no evidence of any significant relation between CEO pay and firm performance (either accounting or market performance) in the prior, current or future year.

Matolcsy et al. (2009) note that prior evidence on the association between market-based measures of performance and stock and option-based compensation reveals both positive and negative effects, and thus they seek to explain these contradictory empirical results. They suggest that stock-based compensation can be used as a reward for past performance (in which case the market will view the grant as an expense) and as an incentive for future performance (in contrast, the market will view the grant as an asset). If stock-based compensation is a reward for past performance, a negative relationship is expected; whereas a positive relationship is expected if these payments are made to provide 
incentives for future performance. They use 259 firm-year observations for 1999-2004 disclosures and divide these into 'reward' and 'incentive' groups using firm prior period return characteristics and the degree of 'at-the-money' of the granted options. An instrumental variables approach is used to control for the mechanical relationship between the value of a share and the value of an option. After controlling for the endogeneity, the results show a statistically positive association for the 'incentive' group; however the 'reward' group is statistically insignificant.

Besides firm size and performance, research studies also endeavor to identify a variety of firm characteristics, CEO characteristics and corporate governance variables that explain the level of CEO compensation in Australia. The rationale behind this is that the determination of compensation arrangements is a jointly-determined process involving the CEO, the compensation committee and its consultants, the Board and the external labour market.

For firm characteristics, the level of CEO compensation is found to be positively related to firm size, the idiosyncratic risk of the firm (Chalmers et al., 2006), growth opportunities (Heaney et al., 2010; Walker, 2010), Tobin's Q (Schultz et al., 2013) and business complexity (Matolcsy and Wright, 2006), and negatively related to financial leverage (Schultz et al., 2013). For instance, Matolcsy and Wright (2006) examine the relation between CEO compensation and firm characteristics for a sample of about 250 Australian firms among the 'Top 500' during 1999-2001. Consistent with efficient contracting theories, they find that levels of Australian CEO compensation are associated with the firm's underlying economic characteristics, which explain around $41.5 \%$ of cross-sectional variation in the levels of CEO pay. The level of CEO compensation is found to be positively related to firm size, firm complexity (measured by the number of subsidiaries) and current stock price performance.

With respect to CEO characteristics and governance variables, the level of CEO compensation is generally found to be positively related to board size (Chalmers et al., 2006; Heaney et al., 2010; Schultz et al., 2013) and institutional ownership (Doucouliagos et al., 2007), and negatively related to a CEO change (Capezio et al., 2011; Lee, 2009), CEO ownership (Coulton and Taylor, 2002; Chalmers et al., 2006) and insider ownership (Coulton and Taylor, 2002). There is mixed evidence on the relation between CEO pay and CEO duality. Heaney et al. (2010) and Schultz et al. (2013) report a negative relationship, while Lee (2009) and Walker (2010) document a positive or insignificant association. O'Neil and lob (1999) find no significant relation between CEO cash pay and CEO age and the number of CEO service year. 
Importantly, prior research finds that the effectiveness of board monitoring is not significantly related to the level of CEO compensation (Lee, 2009; Capezio et al., 2011; Schultz et al., 2013). For example, Schultz et al. (2013) do not find a consistent relationship between the effectiveness of board monitoring activity and CEO compensation. The proportion of nonexecutive directors and the existence of a remuneration committee are both positively related to CEO pay, which is at odds with the notion that greater monitoring afforded by these characteristics would lower CEO pay. Inconsistent with the incentive effect, there is a negative impact of CEO duality and a CEO serving on the remuneration committee on CEO pay.

Capezio et al. (2011) use top 500 ASX firms for the period of 1998-2006 and examine whether board structural independence is an important boundary condition for the enforcement of CEO pay-forperformance. Employing a system Generalized Method of Moments (GMM), they find that the payperformance relation is not significantly different in firms whose boards are chaired by non-executives and dominated by non-executive directors (at both the full board and compensation committee levels). They also find that the level of CEO cash compensation is influenced by firm size, but not firm performance. They therefore conclude that the results contradict both efficient-contracting and managerial-power theories, and argue that policy makers' faith in incentive plans and the moderating influence of structural independence per se may be misplaced.

On the other hand, Chalmers et al. (2006) use the enhanced executive remuneration disclosure regulations introduced in Australia on 1 July 1998 to examine firm attributes that are associated with and explain differences in CEO pay levels, and whether CEO compensation and performance relationships are consistent with labour demand theory (efficient contracting) or rent extraction (managerial power). Total compensation is found to be significantly positively related to size, ROA, the idiosyncratic risk of the firm and board size, while a significant negative relationship is found for CEO ownership. When considering different components of CEO pay, they find the fixed salary and sharebased components of compensation are consistent with efficient contracting explanations, while bonuses and option grants are found to be consistent with rent extraction (particularly for smaller firms and for firms with above average performance). The rent extraction is statistically significant, though it is economically negligible and short-lived, in contrast to US evidence where rent extraction is wide-spread, persistent and economically substantial (at least according to Core et al., 1999).

\subsubsection{The trend of Australian CEO pay}


In its report on executive remuneration, the Productivity Commission (2009, p. 41) notes that from 1993 to 2009, average compensation of ASX100 CEOs increased in real term at an average rate of 6-7 per cent, equivalent to an increase from 17 times average earnings in Australia in 1993 to 42 times in 2009. The rise is significantly stronger in the 1990s (at a rate of $12 \%$ ), with slower but still positive growth from 2000-2007.

Pottenger and Leigh (2013) present a long-term perspective of executive compensation for BHP, the resources giant and one of the largest companies in Australia, over 1887-2013. Similar to the pattern in US CEO compensation and Australian top incomes, they find the trend in director remuneration (relative to average earnings) follows a U-shape. Specifically, the pay to executives and directors in BHP increased from the 1880s to the 1910s, trended downwards through the 1920s and into the 1930s, rose briefly during World War II and fell again from the 1940s until the 1980s. However, director pay has increased dramatically over recent decades, consistent with the average trends in executive compensation in top Australian firms. They therefore suggest that Australia experienced a 'great compression' in executive salaries during the post-war era, followed by the recent 'great divergence' in the late-twentieth century. The documented pattern is similar to the long-term analysis of US CEO pay and the managerial labour market in Frydman and Saks (2010) and Piketty and Saez (2003).

Matolcsy et al. (2012) consider a unique setting where Australian companies have changed from cash bonus to equity-based compensation, and examine determinants and performance consequences of changes in CEO compensation structure. According to efficient contracting theories, they argue that the change to equity-based compensation is driven by changes in firm characteristics and by the occurrence of CEO turnover, the latter of which provides a less costly opportunity for such change. Using a sample of 2,288 firm-years over 2001-2009, they find larger firms with more business segments and higher investment opportunities are more likely to change their compensation structure. The likelihood is also higher when there is a change in CEO in the firm. They also document a significant negative association between changes in compensation structure and the firm's financial and stock price performance in the following year, even after controlling for CEO turnover and poor governance environments. They suggest that the initial change to equity-based compensation is part of an error learning process made by firms that leads them towards efficient CEO compensation contracts.

Hill et al. (2011) present an insightful comparison in CEO employment contracts between Australia and US. They create pairs of US and Australian firms matched on firm size, industry and contract starting 
date. They find that Australian CEOs have significantly greater base salaries than their US counterparts, but are less likely to be compensated with restricted stock and stock options. Interestingly, the employment contracts for Australian CEOs tend to be shorter than US contracts, and have more restrictions on CEO actions. In contrast, employment contracts for US CEOs are more likely to have arbitration provisions, change-in-control provisions, tax gross ups, do not compete clauses, and supplementary executive retirement plans (SERPs). Hill et al. (2011) suggest that some of the differences reflect underlying differences in the legal, regulatory and cultural environment. For example, the relative infrequency of change-in-control provisions in Australian contracts may be due to the more stringent ASX listing requirements. Vast differences in arbitration provisions may reflect cultural differences. However, a better understanding of institutional differences such as tax codes, takeover protection and corporate governance practice is still needed to help explain some remaining differences in CEO contracts between Australia and the US.

\subsubsection{CEO pay-performance sensitivity}

Early research on CEO pay-performance sensitivity in Australia presents mixed evidence, partly due to the fact that these studies use total cash-based compensation and do not include equity-based pay (because disclosure was not required during these sample periods). Izan et al. (1998) present preliminary evidence on an insignificant and close to zero pay-performance sensitivity for total cash compensation over 1987-1992. Merhebi et al. (2006) study the Top 500 firms over 1990-1999, and report evidence consistent with efficient contracting explanations. They find that: (1) changes in CEO cash pay is positively associated with the change in current and lagged period shareholder wealth (a CEO receives a 1.16 per cent increase in pay for a 10 per cent increase in shareholder wealth) and (2) CEO pay sensitivity decreases as the riskiness of the firm increases.

Recent studies include both cash-based and equity-based compensation, and generally document statistically significant pay-performance sensitivity, albeit the magnitude is not economically significant. Clarkson et al. (2011) investigate the effect of increased shareholder oversight and disclosures about executive remuneration on the pay-performance sensitivity by controlling for contemporaneous changes in corporate governance practice. Using a sample of 240 firms with annual reports available for each year over 2001-2009, they find a general improvement in pay-performance sensitivity over the study period. The sensitivity increase is primarily related to enhanced remuneration disclosure and the non-binding shareholder vote on the remuneration report. They therefore conclude that enhanced 
oversight of executive remuneration arrangements resulting from regulatory change has a positive impact on executive compensation arrangements.

Schultz et al. (2013) examine the role of corporate governance mechanisms, namely blockholdings and board structure, in shaping pay-performance sensitivity using a large sample of Australian firms over 2000-2009. They find monitoring by outside blockholders increases the sensitivity of long-term at-risk pay-to-performance, thereby better aligning manager and shareholder interests. However, insider blockholders increase (decrease) the sensitivity of cash bonuses (long-term at-risk pay) to performance, indicative of differences in the horizons of managers and outsiders. They also find that larger boards are associated with lower sensitivity of at-risk pay, consistent with them affording less effective monitoring.

Monem and Ng (2013) consider a unique setting where the 'two-strikes' rule (i.e., the 'say-on-pay' legislation) was first introduced in Australia in 2011, and investigate the consequences of the regulatory change for pay-performance sensitivity. Using a sample of 104 firms in 2011 and 105 firms in 2012 that experienced the 'first strike', they find no difference in pay-performance sensitivity between the 'first strike' firms and the control firms. Shareholder voting power (measured by the ratio of 'no' votes to the total number of votes) has little impact on the pay-performance link. They conclude that the shareholders of the 'first-strike' firms may have been over-enthusiastic about their voting power in 2011 but exercised this power more judiciously in 2012, as the pay-performance relations improved slightly in 2012.

It is important to note that most Australian studies do not consider changes in the value of the CEO's stock and option portfolio as a significant component of total compensation (Jensen and Murphy, 1990; Core et al., 2003), partly due to the unavailability of CEO ownership data. Some studies argue that the rationale for excluding such changes in the CEO's wealth in assessing the pay-performance sensitivity is that rational shareholders are more likely to focus on compensation granted in the current year than on wealth accumulated through past equity and option grants, at least in the scenario they examine (for example, 'say on pay' as in Monem and $\mathrm{Ng}, 2013$ ). However, a comprehensive measure of CEO incentives (pay-performance sensitivity) should take all possible links between firm performance and CEO wealth into account. The exclusion of changes in the value of the CEO's stock and option portfolio therefore is likely to systematically underestimate the level of incentives (Jensen and Murphy, 1990; Frydman and Jenter, 2010).

\subsubsection{CEO pay, firm performance and corporate actions}


There is very limited Australian empirical evidence on the effect of CEO compensation on firm performance and corporate actions. To our knowledge, there are only three studies that present preliminary evidence in the area of firm performance (Matolcsy and Wright, 2011), merger and acquisitions (Bugeja et al., 2012) and corporate investment (Li et al., 2011). Therefore, future research with careful design and an insightful setting is particularly needed to enrich our understanding of CEO compensation in Australia.

Matolcsy and Wright (2011) use 3,053 firm-years drawn from 1999-2005 disclosures made by Top 500 firms to investigate efficient and inefficient CEO compensation structures, and their effects on firm performance. Approximately $30 \%$ of these firm-years have cash only compensation systems, while the remaining firms use both cash and equity-based compensation. They predict that firms that adopt CEO compensation structures that deviate from the 'efficient compensation structure' have lower performance than firms that have an efficient structure. Performance is measured using both accounting-based measures (return on assets and return on equity) and market-based measures (fullydiluted change in the stock price and fully-diluted change in the stock price adjusted for CAPM beta risk). They estimate a cross-sectional logit model using data for all firm-years ${ }^{11}$ where the dependent variable equals one for the equity-based group and two for the cash group. The independent variables include proxies for size, the market-to-book ratio, firm performance, earnings volatility, leverage and CEO and blockholder ownership. The logit model results are then used to "predict which compensation group a firm could belong to" (p. 755). The performance of firms in and not in the predicted group is then investigated ${ }^{12}$, with those not in the 'optimal' group predicted to have worse performance. The results confirm this prediction for all four performance measures.

Bugeja et al. (2012) investigate CEO compensation in mergers and acquisitions and conclude that overall their findings are more consistent with the predictions of incentive alignment effects of efficient contracting than managerial power theory, albeit that these theories are not mutually exclusive and that some evidence is consistent with managerial power. They use a sample of 177 M\&A deals and 4,002 control firms drawn from 2000 to 2007 and show that CEO compensation increases significantly in the M\&A completion year and the subsequent year. All components of CEO compensation (salary only, bonus only, salary and bonus, shares, options and total compensation) are found to increase. CEOs with

\footnotetext{
${ }^{11}$ Matolcsy and Wright (2011) also estimate this logit model each year and find results that are generally the same as the main results with respect to sign of the 'wrong group' dummy, though not all cases are statistically significant.

${ }^{12}$ Approximately 95 per cent of the equity group and 25 per cent of the cash group are correctly predicted.
} 
longer tenure and those with bigger boards are paid more, as too are CEOs of deals that have a more negative announcement effect (consistent with managerial power) however other measures of managerial power (CEO on the nominating committee, higher CEO ownership and the proportion of insiders on the board) are significantly negatively related to CEO compensation (consistent with efficient contracting). The study also shows that CEO compensation in acquiring firms is positively related to measures of performance (return on assets and stock market performance). Finally CEOs are paid more for bigger takeovers, if they acquire targets in different industries and if they revise (upwards) the original offer price to the target.

Li et al. (2011) provide some preliminary evidence on the relation between executive compensation and corporate investment for the period over 2004-2007. They document a significant positive relation between corporate investment levels and equity-based compensation for all executives and directors relative to market value of equity. However, the relation is not significant when equity-based compensation is measured as a ratio of total compensation for all executives and directors. Li et al. (2011) argue that equity-based compensation relative to market value of equity has a more direct link with shareholders' wealth, and suggest that managers make investment decisions that positively affect their equity-based compensation.

\section{DESIGN PRINCIPLES}

Murphy (2013) concludes (in part) his comprehensive analysis of the evolution of US CEO remuneration with the following: "Indeed, what makes CEO pay both interesting and complicated is the fact that the efficient contracting, managerial power, and political paradigms co-exist and interact" (Murphy, 2013, p. 346). Similarly Ferrarini et al.'s (2009) survey of European regulation on CEO remuneration highlights that: "Establishing rules or guidelines on optimal pay, which also respond to public concerns with respect to fairness, is not an easy task" (Ferrarini et al., 2009, p. 5). Nonetheless, we 'put our heads on the chopping block' by outlining a set of design principles for executive compensation contracts. Our motive is in to generate debate, discussion and hopefully consensus.

Cronqvist and Fahlenbrach (2012) investigate the way CEO compensation contracts change when public firms are acquired in a leveraged buyout (LBO) by private equity firms, which the authors regard as among the most financially sophisticated principals in US capital markets. A (small and non-random) 
sample of 20 large LBOs made between 2005 and 2007 by the largest US private equity firms is used. They find several contract features, but not all, are redesigned, as follows:

- CEO base salary and bonuses increase by around 25 per cent, particularly when new executives are hired to work in these highly levered organisations.

- A more performance-sensitive contract is negotiated where CEO effort is important. Contracts are redesigned so as to avoid qualitative, nonfinancial and earnings-based measures. Cash-flow based measures, such as earnings before interest, taxes, depreciation and amortization (EBITDA) that allow less accounting discretion than earnings, are adopted for short-term measures of performance. Longer term performance is measured using internal rates of return (IRR) or multiples of estimated firm value to acquisition price. A common contract provision is that about 50 per cent of equity grants will performance-vest if IRR and multiple hurdles are met at exit.

- CEO severance pay multipliers remain unchanged.

- Unvested options and restricted stock grants are typically forfeited if a CEO is dismissed.

- The sale of vested shares for dismissed executives is restricted, typically through a right of first refusal and limits on the set of parties that can acquire vested stock. Dismissed CEOs find it practically impossible to unwind their vested equity positions.

- Perquisites, such as personal usage of firm assets and tax gross-ups, remain unchanged after the PE transaction.

Murphy and Jensen (2011) argue that their research and consulting experience leads to a conclusion that almost all CEO and executive bonus plans are deeply flawed, resulting in counterproductive incentives and decisions that harm shareholders. Their paper first describes a typical bonus plan and then moves to a discussion of using the wrong pay-performance relationships, the wrong standards or targets, the wrong performance measures, ex-post adjustment to bonuses (including clawbacks) and the role of banking bonuses in the GFC. The paper contains a series of 10 recommendations for bonus plan design.

A typical bonus plan, drawn from Murphy and Jensen (2011, p. 4) is depicted below:

\section{Figure 1 A Typical Bonus Plan}




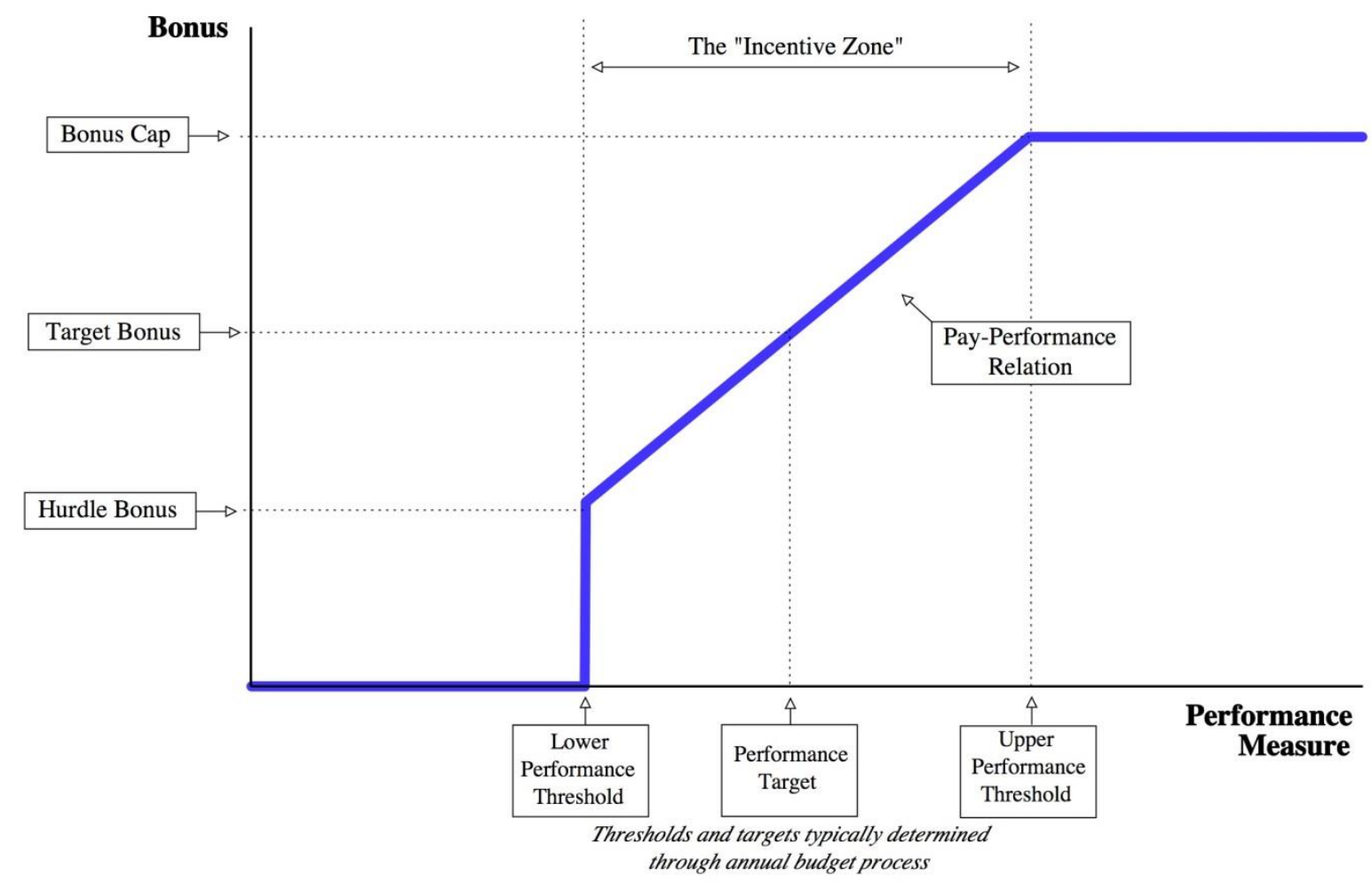

Typical bonus plan, often referred to by compensation consultants as an '80/120 plan'. A performance target and a target bonus for meeting that performance are set. Upper and lower performance thresholds are established which create an 'incentive zone' within which the bonus increases with performance. Bonuses do not vary with performance outside the range established by the Lower and Upper Performance thresholds. A Hurdle Bonus is often paid when the executive reaches the lower performance threshold. The bonus can increase linearly with performance in the incentive zone (as shown here) or it can increase at a decreasing rate or an increasing rate (that is, the line can be convex or concave).

Murphy and Jensen (2011) argue that Figure 1 "is replete with incentive problems that destroy value". Suppose a CEO has an upper hurdle for ROE of 15 per cent, but is confident that the firm can easily surpass that threshold. A CEO they interviewed stated "I'd have to be the stupidest CEO in the world to report an ROE of $18 \%$. First, I wouldn't get any bonus for any results above the cap. Second, I could have saved some of our earnings for next year. And third, [the board of directors] would increase my target performance for next year." A bonus plan like this also motivates earnings management, sometimes taking a 'big bath' and it encourages low-balling in setting performance targets. They are also short-term in their focus. And, importantly, the pay-performance relationship is non-linear.

Accordingly, Murphy and Jensen recommend (R1) that non-linear pay-performance be replaced by linear plans. The typical bonus plan in Figure 1 above also encourages people to lie. Accordingly Murphy and Jensen (2011, p. 19) recommend (R2) the separating of the budgeting process from the targets set 
in compensation formulas. It is clear that allowing managers to select their peer group for performance evaluation potentially involves perverse incentives, accordingly R3 states that executives should not be responsible for selecting the comparison group. It is also clear that a benchmark set this year that incorporates prior-year performance will ensure that executives who perform well in one year will be penalized the next. Accordingly R4 states that current year incentives should not be tied to prior performance while R5 states that incentive payments should not be tied benchmarks that the CEO can influence.

It has been long-recognized that ratios can be affected by altering the numerator or the denominator. Typically bonus plans want to encourage the numerator to be increased (because the numerator typically uses measures such as revenue, earnings, EBIDTA) however the value of ratio can be increased if the denominator is managed downward. Typically managing the value of the denominator downward (assets, sales or equity) is value destroying. Murphy and Jensen (2011) somewhat controversially recommend, given the prevalence of measures such as ROA or ROE ${ }^{13}$, in $\mathrm{R} 6$ that ratios should not be used as performance measures.

CEOs can and do influence capital structure and a firms' cost of capital. The distinction between accounting profit and economic profit (Economic profit = Accounting profit - Cost of capital X Amount of capital) is that economic profit incorporates the opportunity cost of capital employed in the firm. R7 recommends that performance measures should incorporate the cost of equity capital. It is virtually impossible to make fool-proof objective and accurate measures of the contribution of an individual to firm value. Accordingly Murphy and Jensen suggest that compensation committees should have the power to make after-the-fact ex post adjustments to both the measure of CEO performance and the compensation actually paid to the CEO. Accordingly they make a series of recommendations (R8 to R10) to address these concerns, as follows:

- $\quad$ R8 recommends that incentive plans should include a subjective component.

- $\quad$ R9 requires that CEOs should be held accountable for factors that are beyond their control if they can control or affect the impact of those uncontrollable factors on performance, and

\footnotetext{
${ }^{13}$ Murphy and Jensen (2011, pp. 35-37) show that ratio measures can quite easily be converted to 'valid' performance hurdles providing the compensation committee decides on an appropriate proportion of the dollar amount of the numerator of a ratio as going into a bonus pool.
} 
- R10 recommends that incentive programs should provide for clawback of rewards, especially when data were manipulated or fraudulent. Bonus banks or deferred compensation are recommended.

While we agree with many of the recommendations made by Murphy and Jensen (2011) we came up, quite independently with a different set of principles. Murphy and Jensen's recommendations focus on bonus plans, while ours are somewhat broader in scope. In developing these principles we were encouraged by colleagues to set out our views in the spirit of having a blank sheet of paper, though recognizing that the separation of ownership and control, and the attendant agency and incentive problems that result, need to be incorporated into CEO compensation contracts. Here is our list.

1. Executive compensation should consist of two broad elements, a base pay and a flexible bonus element.

2. The base pay should be set taking into account the market for managerial talent. It can be adjusted to reflect changes in the market for managerial talent.

3. The bonus element should be based on performance of the firm, and its payment should vest over several years depending on performance outcomes over those years.

4. The bonus amount or bonus pool should be based on a share of the risk-adjusted wealth increase that shareholders have achieved in the contemporaneous period.

5. Bonus payments can be divided into equity-linked, cash and perquisite components. It should be recognized that a CEO values equity-linked compensation at less than the cost of those awards to shareholders.

6. Equity-based compensation grants should be adjusted for dividend payments. The exercise price of executive options should be adjusted downward, while restricted stock should have dividend entitlements and the entitlement to shares should be adjusted upward by assuming the dividend is re-invested to acquire additional stock.

7. Performance measurement is subject to measurement error, and accordingly performance should be classified as (i) statistically superior to the benchmark (ii) statistically indistinguishable from the benchmark and (iii) statistically below the benchmark. Performance that is statistically below the benchmark should result in no bonus reward for the current period. The performance bonus should be higher for statistically superior performance than it is for performance that is 
statistically indistinguishable from the benchmark. The performance rankings should be positively correlated to the bonus pool.

8. Firm performance should be measured relative to an appropriate independently selected set of peers taking risk into account. Bonus awards should be based on a measure of abnormal performance calculated as the firm's actual performance less the performance that is expected, given the actual performance of the benchmark peers. Firms with listed securities should use sharemarket returns in assessing abnormal performance, if the securities are efficiently priced ${ }^{14}$. Audited accounting-based measures of performance can also be used providing that these are prepared on a consistent basis. Audited cash-flow measures of performance should be used as a check on the reasonableness of earnings measures. Accounting measures of performance should be adjusted for the cost of capital.

9. Termination payments should be a function of the benchmark adjusted performance of the firm during the tenure of the executive. Three broad categories of performance (as in 7 above) should be developed. Entitlements to incentive payments that have been earned but that have not yet vested should vest on a CEOs resignation, however these should be subject to some clawback. A CEO who is dismissed for poor performance or inappropriate or illegal conduct should receive no termination bonuses.

We illustrate the application of the measurement of the performance element for six prominent ASX listed companies (not randomly selected) in Table 10. The six companies, and their CEOs and appointment terms are as follows:

1. Telstra Corporation Limited (ASX code TLS). We evaluate the performance of BHP during the term of Solomon Trujillo, who was the CEO from July 2005 to May 2009.

2. Air New Zealand (ASX code AIZ). Robert Fyfe was appointed as the CEO in October 2005, and left his position in December 2012.

\footnotetext{
${ }^{14}$ In Cammer v. Bloom (1989) Civil Action No. 88-2458, United States District Court for the District of New Jersey, Judge Alfred J. Lechnmer outlined five factors that have become known as the 'Crammer factors' that that would help establish whether a security traded in an efficient market. Since then, dozens of courts have relied on the five 'Cammer factors' in evaluating market efficiency. The factors are "(1) the stock's average weekly trading volume; (2) the number of securities analysts that followed and reported on the stock; (3) the presence of market makers and arbitrageurs; (4) the company's eligibility to file a Form S-3 Registration Statement; and (5) a cause-and-effect relationship, over time, between unexpected corporate events or financial releases and an immediate response in stock price. Since then Courts have supplemented the five Cammer factors with other measures such as market capitalization, bid/ask spread, float, and analyses of autocorrelation.
} 
3. Caltex Australia Limited (ASX code CTX). David Reeves who was the CEO from August 2003 to May 2006.

4. QGC Pty Limited (formerly Queensland Gas Company Limited, ASX code QGC). Richard Cotte was the CEO from October 2002 to November 2008.

5. Mirvac Group (ASX code MGR). Gregory Paramor was appointed as the CEO in June 2001, and resigned in May 2011.

6. Clough Limited (ASX code CLO). David Singleton was the CEO from August 2003 to January 2007.

For each of these companies we estimated the CAPM, the Market Model, the Fama-French threefactor model and the Carhart four-factor model using data from the SPPR database held at Sirca over the period of time during which the CEOs listed above were in that position. ${ }^{15}$ The index value we used is a weighted value of all companies in the SPPR database. For illustration we used monthly returns, though SPPR does allow these models to be estimated with more granular observations. Our results are presented in Panel A and Panel B of Table 10, where the results in Panel B are based on returns adjusted for dividend imputation franking credits. In summary, the results in Panel A show that:

- Caltex and QGC have a significant positive $\alpha$, ranging from 4.44 to 5.48 per cent per month. David Reeves and Richard Cottee would be judged to have delivered significant shareholder wealth creation, and hence they would be entitled to participate in the full bonus pool. This bonus however would not be paid immediately, and would vest over several years, in accordance with principle 3.

- The $\alpha$ of Telstra, Air New Zealand (AirNZ) and Mirvac is insignificantly different from zero. Hence Solomon Trujillo, Robert Fyfe and Gregory Paramor (Mirvac Group), while not delivering significantly positive performance, was the CEO during a period where TLS, CBA and Mirvac respectively earned, on a risk-adjusted performance, almost exactly what would be expected under the CAPM, the Market Model or the multifactor models. During this period of time Solomon Trujillo and Robert Fyfe would earn a bonus, though it would not be the full award. Gregory Paramor had performance that was also statistically indistinguishable from zero, and hence would be considered for a bonus payment. His bonus would however be lower than that for the Telstra and AirNZ CEOs. In all three cases these bonus payments would vest over several years.

\footnotetext{
${ }^{15}$ We thank Adrian Lee for sharing the series of pricing factors in Australia.
} 
- David Singleton managed Clough Limited during a period of time where the risk-adjusted sharemarket performance was significantly negative. He would be not entitled to performance-based incentive payments or a termination bonus.

The results in Panel B of Table 10 are qualitatively and quantitatively similar to those in Panel A, suggesting that, for the six prominent ASX listed companies, the adjustment for dividend imputation franking credits does not alter the evaluation of risk-adjusted sharemarket performance over the period of time during which the CEOs were in the position.

Table 11 shows the distribution of $\alpha$ estimated from four different models for all Australian CEOs who were in the position for at least one year. The date of CEO appointment and the date of resignation are sourced from Sirca Limited and Boardroom. We only consider CEOs who have left their position because both databases contain a large number of missing or obviously incorrect values in either date of appointment or date of resignation. Due to estimation requirement, we use monthly stock price data and only examine CEOs who were in the position for at least 12 months. To ensure the efficiency of the security prices, we eliminate observations with stale closing price (i.e., the closing price of current month comes from an earlier month). Below are observations on the estimated $\alpha$ for four different models without (Panel A) and with (Panel B) adjustment for dividend imputation franking credits:

- The mean value of estimated $\alpha$ for CAPM is positive (0.0003), while the other three models report a negative mean value of $\alpha$. The estimated $\alpha$ from the multifactor models tends to be more dispersed, with a higher standard deviation compared to that of the CAPM and the Market model.

- The risk-adjusted sharemarket performance during the period when CEOs were in the position is positive for $52.6 \%$ and $51.1 \%$ of CEOs respectively according to the CAPM and the Market model. The ratio of positive $\alpha$ is lower for the multifactor models. Consistently, the ratio of negative $\alpha$ for the CAPM and the Market model is lower than that for the multifactor models. Similarly, the number and percentage of statistically significant positive $\alpha$ is higher for the CAPM (12.2\%) and the Market model (11.5\%), while the multifactor models result in a higher percentage of significantly negative $\alpha(12.2 \%$ and $11.2 \%$ respectively).

- After the adjustment for dividend imputation franking credits, the ratio of positive (negative) a becomes lower (higher) compared to the estimates with no adjustment. For 
example, the risk-adjusted sharemarket performance during the period when CEOs were in the position is positive for $51.1 \%$ and $45.8 \%$ of CEOs respectively according to the CAPM and the Fama-French three-factor model. Importantly, the number and percentage of statistically significant positive $\alpha$ is higher for the CAPM ( $12.6 \%$ compared to $12.2 \%$ without adjustment), and the percentage of negative $\alpha$ is also higher (10.4\% compared to $9.5 \%)$. This confirms the importance of accounting for dividend imputation franking credits when evaluating risk-adjusted sharemarket performance.

We also compare the estimated $\alpha$ between CEOs who had been in the position for more than three years ('long-service CEO') and those who worked as the CEO for less than three year ('short-service CEO'). Importantly, we find that the mean value of the estimated $\alpha$ for 'long-service CEOs' is positive for all four models, and is higher than the mean negative $\alpha$ for 'short-service CEOs'. The risk-adjusted sharemarket performance for 'long-service CEOs' has a higher percentage of positive and significant values, and a lower percentage of negative estimated values, compared to 'short-service CEOs'. Consistent with the above results, the ratio of positive (negative) $\alpha$ becomes lower (higher) after adjusting for dividend imputation franking credits. However, the percentage of statistically significant $\alpha$ (either positive or negative) is generally higher for the CAPM model and the multifactor models.

Graphical representations of the distribution of estimated $\alpha$ for all CEOs, 'long-service CEOs' and 'short-service CEOs' estimated from the CAPM and the Fama-French three-factor model are reported in Figures 7,8 and 9.

\section{CONCLUSIONS}

Executive compensation has been controversial for several decades. Recent controversies over executive pay have sparked outrage from some sectors and calls for increased regulation and reform. Yet others argue that knee-jerk reactions to perceived abuses of pay can lead to a host of unintended and inefficient outcomes. This paper argues that much of this controversy is due to executives being rewarded via contracts that have weaknesses in design. We argue that few stakeholders in firms would object to generous appropriately generous compensation for managers whose performance results in abnormally high long-term shareholder wealth creation. We state a set of nine design principles, developed from our intuition and a review of the extensive theoretical, regulatory and empirical

literature, that we suggest should be the fundamental building blocks for designing executive 
remuneration systems in public firms, especially where ownership and control is separated. Our purpose is to generate broad debate and discussion hopefully leading to a consensus as to the principles that should be present in all executive compensation contracts such that the interests of shareholders and managers are aligned.

We illustrated the principles we have developed using six well-known ASX listed firms managed by high-profile CEOs. While these firms were not chosen randomly, the illustration is robust to the various methods we use to estimate risk-adjusted sharemarket performance.

It goes without saying, perhaps, that comments, criticisms and suggestions are welcome. 
Table 1: Mean and median CEO compensation for all firms included in the Sirca Limited corporate governance database for 2001 to 2012 , where all dollar values are adjusted to December 2012 dollars using the Australian CPI*.

\begin{tabular}{|c|c|c|c|c|c|c|c|c|c|c|c|c|c|}
\hline \multirow[b]{2}{*}{ Year } & \multirow[b]{2}{*}{ NOB } & \multicolumn{5}{|c|}{ Mean } & \multirow[b]{2}{*}{$\begin{array}{l}\text { Change in } \\
\text { total comp. } \\
\text { from } t-1\end{array}$} & \multicolumn{5}{|c|}{ Median } & \multirow[b]{2}{*}{$\begin{array}{l}\text { Change in } \\
\text { total comp } \\
\text { from } t-1\end{array}$} \\
\hline & & $\begin{array}{c}\text { Cash } \\
\text { comp. }\end{array}$ & $\begin{array}{l}\text { Cash } \\
\text { ratio }\end{array}$ & $\begin{array}{l}\text { Equity } \\
\text { comp. }\end{array}$ & $\begin{array}{l}\text { Equity } \\
\text { ratio }\end{array}$ & $\begin{array}{l}\text { Total } \\
\text { comp. }\end{array}$ & & $\begin{array}{l}\text { Cash } \\
\text { comp. }\end{array}$ & $\begin{array}{l}\text { Cash } \\
\text { ratio }\end{array}$ & $\begin{array}{l}\text { Equity } \\
\text { comp. }\end{array}$ & $\begin{array}{l}\text { Equity } \\
\text { ratio }\end{array}$ & $\begin{array}{l}\text { Total } \\
\text { comp. }\end{array}$ & \\
\hline All & & & & & & & & & & & & & \\
\hline Years & 11282 & 817,514 & $78.5 \%$ & 210,460 & $20.2 \%$ & $1,041,461$ & & 410,714 & $87.8 \%$ & 57,228 & $12.2 \%$ & 467,942 & \\
\hline 2001 & 881 & 648,519 & $90.8 \%$ & 61,092 & $8.6 \%$ & 714,343 & & 341,181 & $96.1 \%$ & 13,958 & $3.9 \%$ & 355,140 & \\
\hline 2002 & 903 & 701,938 & $88.9 \%$ & 86,480 & $11.0 \%$ & 789,604 & $10.5 \%$ & 355,333 & $97.7 \%$ & 8,414 & $2.3 \%$ & 363,747 & $2.4 \%$ \\
\hline 2003 & 914 & 739,514 & $85.8 \%$ & 109,340 & $12.7 \%$ & 862,358 & $9.2 \%$ & 362,324 & $94.4 \%$ & 21,385 & $5.6 \%$ & 383,709 & $5.5 \%$ \\
\hline 2004 & 974 & 775,085 & $86.2 \%$ & 122,884 & $13.7 \%$ & 899,062 & $4.3 \%$ & 357,455 & $89.8 \%$ & 40,650 & $10.2 \%$ & 398,105 & $3.8 \%$ \\
\hline 2005 & 1006 & 805,358 & $82.2 \%$ & 172,032 & $17.6 \%$ & 979,186 & $8.9 \%$ & 376,226 & $87.2 \%$ & 55,133 & $12.8 \%$ & 431,359 & $8.4 \%$ \\
\hline 2006 & 1020 & 829,540 & $76.2 \%$ & 217,094 & $19.9 \%$ & $1,088,945$ & $11.2 \%$ & 409,182 & $84.7 \%$ & 73,707 & $15.3 \%$ & 482,888 & $11.9 \%$ \\
\hline 2007 & 1030 & 924,135 & $73.4 \%$ & 325,896 & $25.9 \%$ & $1,258,379$ & $15.6 \%$ & 417,678 & $80.5 \%$ & 100,946 & $19.5 \%$ & 518,624 & $7.4 \%$ \\
\hline 2008 & 991 & 876,693 & $73.4 \%$ & 292,323 & $24.5 \%$ & $1,194,480$ & $-5.1 \%$ & 436,681 & $79.9 \%$ & 109,597 & $20.1 \%$ & 546,278 & $5.3 \%$ \\
\hline 2009 & 961 & 909,694 & $78.4 \%$ & 244,783 & $21.1 \%$ & $1,160,065$ & $-2.9 \%$ & 448,710 & $87.0 \%$ & 67,167 & $13.0 \%$ & 515,877 & $-5.6 \%$ \\
\hline 2010 & 921 & 844,823 & $72.8 \%$ & 298,773 & $25.8 \%$ & $1,159,731$ & $0.0 \%$ & 470,389 & $85.0 \%$ & 82,784 & $15.0 \%$ & 553,173 & $7.2 \%$ \\
\hline 2011 & 890 & 846,664 & $73.3 \%$ & 283,934 & $24.6 \%$ & $1,155,101$ & $-0.4 \%$ & 487,491 & $83.7 \%$ & 94,874 & $16.3 \%$ & 582,365 & $5.3 \%$ \\
\hline 2012 & 791 & 890,532 & $73.6 \%$ & 303,287 & $25.1 \%$ & $1,209,961$ & $4.7 \%$ & 533,598 & $82.8 \%$ & 110,724 & $17.2 \%$ & 644,322 & $10.6 \%$ \\
\hline
\end{tabular}

*Small differences between total compensation and the sum of cash compensation and equity compensation are caused by small amounts of other compensation. 
Table 2: Mean and median CEO compensation for top 100 firms included in the Sirca Limited corporate governance database for 2001 to 2012 , where all dollar values are adjusted to December 2012 dollars using the Australian CPI*.

\begin{tabular}{|c|c|c|c|c|c|c|c|c|c|c|c|c|c|}
\hline \multirow[b]{2}{*}{ Year } & \multirow[b]{2}{*}{ NOB } & \multicolumn{6}{|c|}{ Mean } & \multicolumn{6}{|c|}{ Median } \\
\hline & & $\begin{array}{l}\text { Cash } \\
\text { comp. }\end{array}$ & $\begin{array}{l}\text { Cash } \\
\text { ratio }\end{array}$ & $\begin{array}{l}\text { Equity } \\
\text { comp. }\end{array}$ & $\begin{array}{c}\text { Equity } \\
\text { ratio }\end{array}$ & $\begin{array}{l}\text { Total } \\
\text { comp. }\end{array}$ & $\begin{array}{l}\text { Change in } \\
\text { total comp. } \\
\text { from } t-1\end{array}$ & $\begin{array}{l}\text { Cash } \\
\text { comp. }\end{array}$ & $\begin{array}{l}\text { Cash } \\
\text { ratio }\end{array}$ & $\begin{array}{l}\text { Equity } \\
\text { comp. }\end{array}$ & $\begin{array}{c}\text { Equity } \\
\text { ratio }\end{array}$ & $\begin{array}{l}\text { Total } \\
\text { comp. }\end{array}$ & $\begin{array}{l}\text { Change in } \\
\text { total comp. } \\
\text { from } t-1\end{array}$ \\
\hline All & & & & & & & & & & & & & \\
\hline Years & 1200 & $3,135,036$ & $75.0 \%$ & 963,287 & $23.0 \%$ & $4,180,499$ & & $2,358,037$ & $76.6 \%$ & 721,731 & $23.4 \%$ & $3,079,769$ & \\
\hline 2001 & 100 & $2,333,923$ & $90.8 \%$ & 234,287 & $9.1 \%$ & $2,569,813$ & & $1,659,105$ & $91.0 \%$ & 163,307 & $9.0 \%$ & $1,822,413$ & \\
\hline 2002 & 100 & $2,663,347$ & $84.1 \%$ & 494,395 & $15.6 \%$ & $3,168,454$ & $23.3 \%$ & $1,887,424$ & $80.3 \%$ & 463,369 & $19.7 \%$ & $2,350,792$ & $29.0 \%$ \\
\hline 2003 & 100 & $2,867,706$ & $77.7 \%$ & 708,625 & $19.2 \%$ & $3,689,757$ & $16.5 \%$ & $1,952,863$ & $81.0 \%$ & 457,727 & $19.0 \%$ & $2,410,590$ & $2.5 \%$ \\
\hline 2004 & 100 & $3,458,661$ & $84.4 \%$ & 636,293 & $15.5 \%$ & $4,095,924$ & $11.0 \%$ & $2,745,374$ & $84.0 \%$ & 524,813 & $16.0 \%$ & $3,270,187$ & $35.7 \%$ \\
\hline 2005 & 100 & $3,623,498$ & $80.6 \%$ & 864,354 & $19.2 \%$ & $4,495,180$ & $9.7 \%$ & $2,507,077$ & $82.2 \%$ & 543,278 & $17.8 \%$ & $3,050,356$ & $-6.7 \%$ \\
\hline 2006 & 100 & $3,404,534$ & $72.4 \%$ & 973,717 & $20.7 \%$ & $4,703,288$ & $4.6 \%$ & $2,728,890$ & $78.8 \%$ & 732,984 & $21.2 \%$ & $3,461,874$ & $13.5 \%$ \\
\hline 2007 & 100 & $4,252,072$ & $72.2 \%$ & $1,573,407$ & $26.7 \%$ & $5,889,643$ & $25.2 \%$ & $3,001,960$ & $73.3 \%$ & $1,094,308$ & $26.7 \%$ & $4,096,268$ & $18.3 \%$ \\
\hline 2008 & 100 & $3,636,509$ & $71.1 \%$ & $1,288,573$ & $25.2 \%$ & $5,114,690$ & $-13.2 \%$ & $2,608,688$ & $67.7 \%$ & $1,243,240$ & $32.3 \%$ & $3,851,928$ & $-6.0 \%$ \\
\hline 2009 & 100 & $2,996,897$ & $71.5 \%$ & $1,178,963$ & $28.1 \%$ & $4,192,006$ & $-18.0 \%$ & $2,470,031$ & $72.1 \%$ & 955,587 & $27.9 \%$ & $3,425,618$ & $-11.1 \%$ \\
\hline 2010 & 100 & $2,938,895$ & $68.2 \%$ & $1,283,889$ & $29.8 \%$ & $4,312,291$ & $2.9 \%$ & $2,396,190$ & $74.7 \%$ & 812,166 & $25.3 \%$ & $3,208,356$ & $-6.3 \%$ \\
\hline 2011 & 100 & $2,900,287$ & $69.2 \%$ & $1,183,582$ & $28.2 \%$ & $4,190,639$ & $-2.8 \%$ & $2,611,368$ & $75.5 \%$ & 848,309 & $24.5 \%$ & $3,459,677$ & $7.8 \%$ \\
\hline 2012 & 100 & $2,544,108$ & $67.9 \%$ & $1,139,360$ & $30.4 \%$ & $3,744,298$ & $-10.7 \%$ & $1,822,967$ & $68.8 \%$ & 826,889 & $31.2 \%$ & $2,649,856$ & $-23.4 \%$ \\
\hline
\end{tabular}

*Small differences between total compensation and the sum of cash compensation and equity compensation are caused by small amounts of other compensation. 
Table 3: Mean and median CEO compensation for Top 200 firms included in the Sirca Limited corporate governance database for 2001 to 2012 , where all dollar values are adjusted to December 2012 dollars using the Australian CPI*.

\begin{tabular}{|c|c|c|c|c|c|c|c|c|c|c|c|c|c|}
\hline \multirow[b]{2}{*}{ Year } & \multirow[b]{2}{*}{ NOB } & \multicolumn{6}{|c|}{ Mean } & \multicolumn{6}{|c|}{ Median } \\
\hline & & $\begin{array}{l}\text { Cash } \\
\text { comp. }\end{array}$ & $\begin{array}{l}\text { Cash } \\
\text { ratio }\end{array}$ & $\begin{array}{l}\text { Equity } \\
\text { comp. }\end{array}$ & $\begin{array}{c}\text { Equity } \\
\text { ratio }\end{array}$ & $\begin{array}{l}\text { Total } \\
\text { comp. }\end{array}$ & $\begin{array}{l}\text { Change in } \\
\text { total comp. } \\
\text { from } t-1\end{array}$ & $\begin{array}{l}\text { Cash } \\
\text { comp. }\end{array}$ & $\begin{array}{l}\text { Cash } \\
\text { ratio }\end{array}$ & $\begin{array}{l}\text { Equity } \\
\text { comp. }\end{array}$ & $\begin{array}{c}\text { Equity } \\
\text { ratio }\end{array}$ & $\begin{array}{l}\text { Total } \\
\text { comp. }\end{array}$ & $\begin{array}{l}\text { Change in } \\
\text { total comp. } \\
\text { from } t-1\end{array}$ \\
\hline \multicolumn{14}{|l|}{ All } \\
\hline Years & 2400 & $2,241,826$ & $76.9 \%$ & 627,240 & $21.5 \%$ & $2,916,199$ & & $1,489,273$ & $81.9 \%$ & 328,253 & $18.1 \%$ & $1,817,526$ & \\
\hline 2001 & 200 & $1,640,914$ & $89.1 \%$ & 193,858 & $10.5 \%$ & $1,842,285$ & & $1,015,393$ & $87.2 \%$ & 149,579 & $12.8 \%$ & $1,164,972$ & \\
\hline 2002 & 200 & $1,852,749$ & $86.2 \%$ & 290,161 & $13.5 \%$ & $2,148,266$ & $16.6 \%$ & $1,166,278$ & $92.7 \%$ & 92,154 & $7.3 \%$ & $1,258,432$ & $8.0 \%$ \\
\hline 2003 & 200 & $2,064,860$ & $81.6 \%$ & 409,900 & $16.2 \%$ & $2,531,540$ & $17.8 \%$ & $1,297,066$ & $84.5 \%$ & 237,756 & $15.5 \%$ & $1,534,821$ & $22.0 \%$ \\
\hline 2004 & 200 & $2,343,696$ & $85.4 \%$ & 398,949 & $14.5 \%$ & $2,745,960$ & $8.5 \%$ & $1,554,318$ & $91.6 \%$ & 142,934 & $8.4 \%$ & $1,697,252$ & $10.6 \%$ \\
\hline 2005 & 200 & $2,440,173$ & $80.8 \%$ & 574,346 & $19.0 \%$ & $3,021,027$ & $10.0 \%$ & $1,628,186$ & $88.3 \%$ & 214,806 & $11.7 \%$ & $1,842,992$ & $8.6 \%$ \\
\hline 2006 & 200 & $2,480,314$ & $75.3 \%$ & 648,602 & $19.7 \%$ & $3,293,075$ & $9.0 \%$ & $1,731,568$ & $82.6 \%$ & 365,363 & $17.4 \%$ & $2,096,931$ & $13.8 \%$ \\
\hline 2007 & 200 & $2,881,771$ & $72.4 \%$ & $1,064,460$ & $26.7 \%$ & $3,982,271$ & $20.9 \%$ & $1,812,121$ & $71.5 \%$ & 721,247 & $28.5 \%$ & $2,533,369$ & $20.8 \%$ \\
\hline 2008 & 200 & $2,505,782$ & $72.0 \%$ & 867,355 & $24.9 \%$ & $3,480,240$ & $-12.6 \%$ & $1,671,378$ & $72.6 \%$ & 630,405 & $27.4 \%$ & $2,301,783$ & $-9.1 \%$ \\
\hline 2009 & 200 & $2,576,046$ & $76.7 \%$ & 771,156 & $23.0 \%$ & $3,358,419$ & $-3.5 \%$ & $1,554,304$ & $76.3 \%$ & 482,855 & $23.7 \%$ & $2,037,159$ & $-11.5 \%$ \\
\hline 2010 & 200 & $2,185,658$ & $71.1 \%$ & 832,632 & $27.1 \%$ & $3,072,018$ & $-8.5 \%$ & $1,565,365$ & $71.9 \%$ & 611,972 & $28.1 \%$ & $2,177,337$ & $6.9 \%$ \\
\hline 2011 & 200 & $2,071,825$ & $71.1 \%$ & 771,881 & $26.5 \%$ & $2,914,515$ & $-5.1 \%$ & $1,481,272$ & $69.6 \%$ & 647,142 & $30.4 \%$ & $2,128,414$ & $-2.2 \%$ \\
\hline 2012 & 200 & $1,858,121$ & $71.3 \%$ & 703,579 & $27.0 \%$ & $2,604,775$ & $-10.6 \%$ & $1,323,633$ & $73.5 \%$ & 476,189 & $26.5 \%$ & $1,799,822$ & $-15.4 \%$ \\
\hline
\end{tabular}

*Small differences between total compensation and the sum of cash compensation and equity compensation are caused by small amounts of other compensation. 
Table 4: Mean and median CEO compensation for Top 300 firms included in the Sirca Limited corporate governance database for 2001 to 2012 , where all dollar values are adjusted to December 2012 dollars using the Australian CPI*.

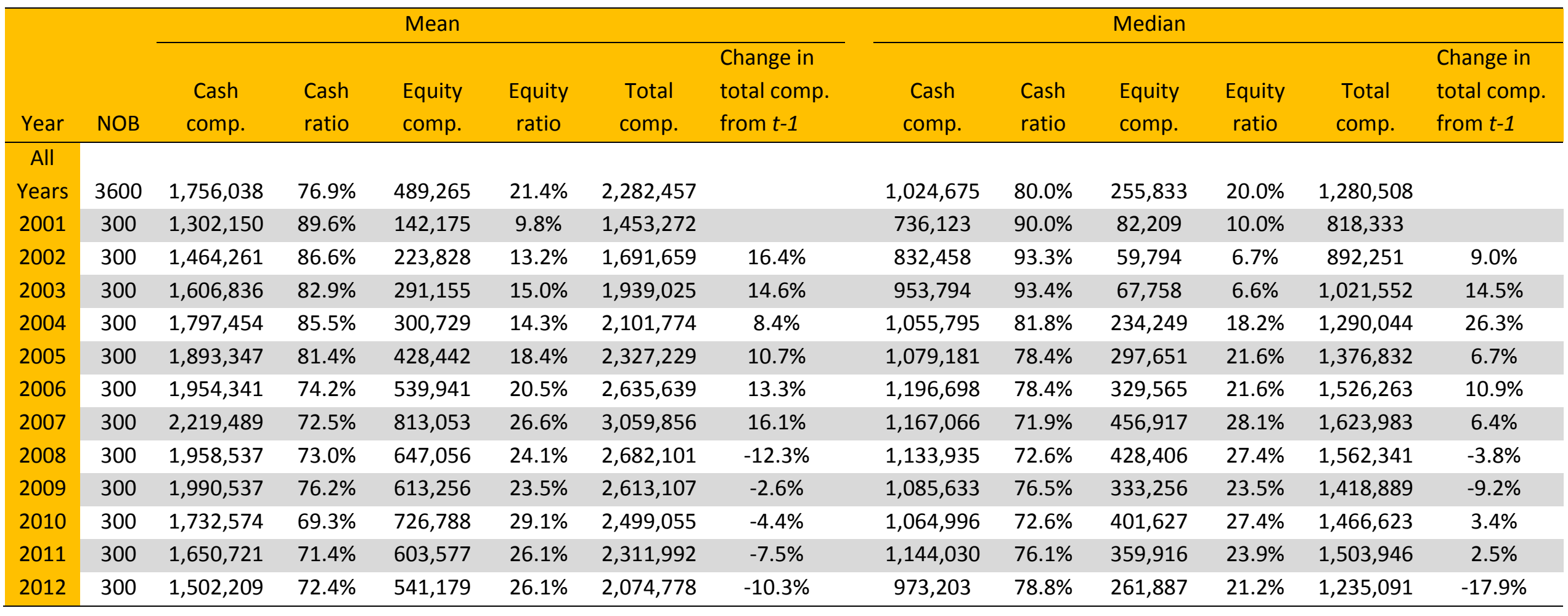

*Small differences between total compensation and the sum of cash compensation and equity compensation are caused by small amounts of other compensation. 
Table 5: Mean and median CEO compensation for Top 101-300 firms included in the Sirca Limited corporate governance database for 2001 to 2012, where all dollar values are adjusted to December 2012 dollars using the Australian CPI*.

\begin{tabular}{|c|c|c|c|c|c|c|c|c|c|c|c|c|c|}
\hline \multirow[b]{2}{*}{ Year } & \multirow[b]{2}{*}{ NOB } & \multicolumn{6}{|c|}{ Mean } & \multicolumn{5}{|c|}{ Median } & \multirow[b]{2}{*}{$\begin{array}{l}\text { Change in } \\
\text { total comp } \\
\text { from } t-1\end{array}$} \\
\hline & & $\begin{array}{l}\text { Cash } \\
\text { comp. }\end{array}$ & $\begin{array}{l}\text { Cash } \\
\text { ratio }\end{array}$ & $\begin{array}{l}\text { Equity } \\
\text { comp. }\end{array}$ & $\begin{array}{c}\text { Equity } \\
\text { ratio }\end{array}$ & $\begin{array}{l}\text { Total } \\
\text { comp. }\end{array}$ & $\begin{array}{l}\text { Change in } \\
\text { total comp. } \\
\text { from } t-1\end{array}$ & $\begin{array}{c}\text { Cash } \\
\text { comp. }\end{array}$ & $\begin{array}{l}\text { Cash } \\
\text { ratio }\end{array}$ & $\begin{array}{l}\text { Equity } \\
\text { comp. }\end{array}$ & $\begin{array}{c}\text { Equity } \\
\text { ratio }\end{array}$ & $\begin{array}{l}\text { Total } \\
\text { comp. }\end{array}$ & \\
\hline All & & & & & & & & & & & & & \\
\hline Years & 2400 & $1,066,539$ & $80.0 \%$ & 252,254 & $18.9 \%$ & $1,333,437$ & & 769,856 & $83.1 \%$ & 156,780 & $16.9 \%$ & 926,636 & \\
\hline 2001 & 200 & 786,263 & $87.9 \%$ & 96,119 & $10.7 \%$ & 895,002 & & 622,100 & $96.7 \%$ & 21,099 & $3.3 \%$ & 643,199 & \\
\hline 2002 & 200 & 864,718 & $90.7 \%$ & 88,544 & $9.3 \%$ & 953,262 & $6.5 \%$ & 674,713 & $93.5 \%$ & 47,179 & $6.5 \%$ & 721,892 & $12.2 \%$ \\
\hline 2003 & 200 & 976,401 & $91.8 \%$ & 82,420 & $7.7 \%$ & $1,063,658$ & $11.6 \%$ & 735,399 & $93.1 \%$ & 54,177 & $6.9 \%$ & 789,576 & $9.4 \%$ \\
\hline 2004 & 200 & 966,851 & $87.5 \%$ & 132,947 & $12.0 \%$ & $1,104,699$ & $3.9 \%$ & 786,197 & $87.6 \%$ & 110,821 & $12.4 \%$ & 897,018 & $13.6 \%$ \\
\hline 2005 & 200 & $1,028,272$ & $82.7 \%$ & 210,486 & $16.9 \%$ & $1,243,254$ & $12.5 \%$ & 796,085 & $86.9 \%$ & 119,531 & $13.1 \%$ & 915,617 & $2.1 \%$ \\
\hline 2006 & 200 & $1,229,245$ & $76.7 \%$ & 323,053 & $20.2 \%$ & $1,601,814$ & $28.8 \%$ & 847,945 & $77.7 \%$ & 243,628 & $22.3 \%$ & $1,091,573$ & $19.2 \%$ \\
\hline 2007 & 200 & $1,203,197$ & $73.1 \%$ & 432,876 & $26.3 \%$ & $1,644,962$ & $2.7 \%$ & 852,197 & $73.6 \%$ & 305,108 & $26.4 \%$ & $1,157,306$ & $6.0 \%$ \\
\hline 2008 & 200 & $1,119,550$ & $76.4 \%$ & 326,298 & $22.3 \%$ & $1,465,807$ & $-10.9 \%$ & 820,979 & $79.3 \%$ & 214,300 & $20.7 \%$ & $1,035,279$ & $-10.5 \%$ \\
\hline 2009 & 200 & $1,487,358$ & $81.6 \%$ & 330,403 & $18.1 \%$ & $1,823,658$ & $24.4 \%$ & 801,670 & $75.1 \%$ & 266,230 & $24.9 \%$ & $1,067,900$ & $3.2 \%$ \\
\hline 2010 & 200 & $1,129,414$ & $70.9 \%$ & 448,238 & $28.1 \%$ & $1,592,437$ & $-12.7 \%$ & 813,124 & $74.1 \%$ & 284,919 & $25.9 \%$ & $1,098,042$ & $2.8 \%$ \\
\hline 2011 & 200 & $1,025,938$ & $74.7 \%$ & 313,574 & $22.8 \%$ & $1,372,669$ & $-13.8 \%$ & 857,561 & $73.3 \%$ & 312,691 & $26.7 \%$ & $1,170,252$ & $6.6 \%$ \\
\hline 2012 & 200 & 981,260 & $79.1 \%$ & 242,088 & $19.5 \%$ & $1,240,017$ & $-9.7 \%$ & 806,288 & $80.2 \%$ & 199,413 & $19.8 \%$ & $1,005,701$ & $-14.1 \%$ \\
\hline
\end{tabular}

*Small differences between total compensation and the sum of cash compensation and equity compensation are caused by small amounts of other compensation. 
Table 6: Mean and median CEO compensation for non-Top 300 firms included in the Sirca Limited corporate governance database for 2001 to 2012, where all dollar values are adjusted to December 2012 dollars using the Australian CPI*.

\begin{tabular}{|c|c|c|c|c|c|c|c|c|c|c|c|c|c|}
\hline \multirow[b]{2}{*}{ Year } & \multirow[b]{2}{*}{$\mathrm{NOB}$} & \multicolumn{5}{|c|}{ Mean } & \multirow[b]{2}{*}{$\begin{array}{l}\text { Change in } \\
\text { total comp. } \\
\text { from } t-1\end{array}$} & \multicolumn{5}{|c|}{ Median } & \multirow[b]{2}{*}{$\begin{array}{l}\text { Change in } \\
\text { total comp } \\
\text { from } t \text { - } 1\end{array}$} \\
\hline & & $\begin{array}{l}\text { Cash } \\
\text { comp. }\end{array}$ & $\begin{array}{l}\text { Cash } \\
\text { ratio }\end{array}$ & $\begin{array}{l}\text { Equity } \\
\text { comp. }\end{array}$ & $\begin{array}{l}\text { Equity } \\
\text { ratio }\end{array}$ & $\begin{array}{l}\text { Total } \\
\text { comp. }\end{array}$ & & $\begin{array}{l}\text { Cash } \\
\text { comp. }\end{array}$ & $\begin{array}{l}\text { Cash } \\
\text { ratio }\end{array}$ & $\begin{array}{l}\text { Equity } \\
\text { comp. }\end{array}$ & $\begin{array}{c}\text { Equity } \\
\text { ratio }\end{array}$ & $\begin{array}{l}\text { Total } \\
\text { comp. }\end{array}$ & \\
\hline All & & & & & & & & & & & & & \\
\hline Years & 7682 & 377,638 & $82.1 \%$ & 79,804 & $17.4 \%$ & 459,819 & & 307,142 & $90.0 \%$ & 33,958 & $10.0 \%$ & 341,100 & \\
\hline 2001 & 581 & 311,015 & $93.5 \%$ & 19,226 & $5.8 \%$ & 332,797 & & 269,132 & $97.0 \%$ & 8,439 & $3.0 \%$ & 277,570 & \\
\hline 2002 & 603 & 322,673 & $94.7 \%$ & 18,147 & $5.3 \%$ & 340,821 & $2.4 \%$ & 263,871 & $98.3 \%$ & 4,490 & $1.7 \%$ & 268,360 & $-3.3 \%$ \\
\hline 2003 & 614 & 315,742 & $93.9 \%$ & 20,506 & $6.1 \%$ & 336,299 & $-1.3 \%$ & 273,175 & $96.7 \%$ & 9,380 & $3.3 \%$ & 282,555 & $5.3 \%$ \\
\hline 2004 & 674 & 320,025 & $88.0 \%$ & 43,724 & $12.0 \%$ & 363,731 & $8.2 \%$ & 258,322 & $93.9 \%$ & 16,636 & $6.1 \%$ & 274,958 & $-2.7 \%$ \\
\hline 2005 & 706 & 343,040 & $84.4 \%$ & 63,075 & $15.5 \%$ & 406,364 & $11.7 \%$ & 290,557 & $89.6 \%$ & 33,732 & $10.4 \%$ & 324,289 & $17.9 \%$ \\
\hline 2006 & 720 & 360,873 & $81.2 \%$ & 82,574 & $18.6 \%$ & 444,489 & $9.4 \%$ & 303,974 & $85.0 \%$ & 53,449 & $15.0 \%$ & 357,424 & $10.2 \%$ \\
\hline 2007 & 730 & 391,799 & $75.6 \%$ & 125,694 & $24.3 \%$ & 518,045 & $16.5 \%$ & 315,039 & $80.8 \%$ & 74,647 & $19.2 \%$ & 389,686 & $9.0 \%$ \\
\hline 2008 & 691 & 407,007 & $74.2 \%$ & 138,315 & $25.2 \%$ & 548,624 & $5.9 \%$ & 341,774 & $85.8 \%$ & 56,547 & $14.2 \%$ & 398,321 & $2.2 \%$ \\
\hline 2009 & 661 & 419,145 & $83.7 \%$ & 77,549 & $15.5 \%$ & 500,591 & $-8.8 \%$ & 349,839 & $90.6 \%$ & 36,421 & $9.4 \%$ & 386,259 & $-3.0 \%$ \\
\hline 2010 & 621 & 415,958 & $81.1 \%$ & 92,002 & $17.9 \%$ & 512,714 & $2.4 \%$ & 340,549 & $85.2 \%$ & 59,221 & $14.8 \%$ & 399,770 & $3.5 \%$ \\
\hline 2011 & 590 & 437,822 & $77.2 \%$ & 121,404 & $21.4 \%$ & 566,851 & $10.6 \%$ & 359,734 & $88.3 \%$ & 47,447 & $11.7 \%$ & 407,181 & $1.9 \%$ \\
\hline 2012 & 491 & 516,035 & $75.8 \%$ & 157,936 & $23.2 \%$ & 680,482 & $20.0 \%$ & 379,981 & $85.2 \%$ & 65,796 & $14.8 \%$ & 445,777 & $9.5 \%$ \\
\hline
\end{tabular}

*Small differences between total compensation and the sum of cash compensation and equity compensation are caused by small amounts of other compensation. 
Table 7: Australian empirical studies on the level of CEO compensation

\begin{tabular}{|c|c|c|c|c|c|c|c|c|c|}
\hline Authors & Year & Sample/Sources & $\begin{array}{l}\text { Sample } \\
\text { year }\end{array}$ & Pay measures & Size & $\begin{array}{l}\text { Prior-year } \\
\text { performance }\end{array}$ & $\begin{array}{l}\text { Current-year } \\
\text { performance }\end{array}$ & $\begin{array}{l}\text { Other } \\
\text { determinants }\end{array}$ & Key findings \\
\hline $\begin{array}{l}\text { Capezio, } \\
\text { Shields and } \\
\text { O'Donnell }\end{array}$ & 2011 & $\begin{array}{l}663(4,456) \text { firms } \\
\text { (firm-yeras) from } \\
\text { ASX top 500, } \\
\text { source unknown }\end{array}$ & $\begin{array}{l}1998- \\
2006\end{array}$ & $\begin{array}{l}\text { Total cash- } \\
\text { based } \\
\text { compensation } \\
\text { and its } \\
\text { components }\end{array}$ & + & & $\begin{array}{l}\text { Current stock } \\
\text { return }(\mathrm{X})\end{array}$ & $\begin{array}{l}\text { Incoming CEO(- } \\
) \text {, board } \\
\text { independence }(X)\end{array}$ & $\begin{array}{l}\text { Board structural independence does not } \\
\text { affect the relation between CEO pay } \\
\text { and performance. The results contradict } \\
\text { both efficient-contracting and } \\
\text { managerial-power theories }\end{array}$ \\
\hline $\begin{array}{l}\text { Chalmers, Koh } \\
\text { and Stapledon }\end{array}$ & 2006 & $\begin{array}{l}133 \text { (532) firms } \\
\text { (firm-years) for } \\
\text { ASX top 200, } \\
\text { annual reports }\end{array}$ & $\begin{array}{l}1999- \\
2002\end{array}$ & $\begin{array}{l}\text { Total } \\
\text { compensation, } \\
\text { salary, bonus, } \\
\text { shares and } \\
\text { options }\end{array}$ & + & $\begin{array}{l}\text { Past } \operatorname{ROA}(+), \\
\text { past return }(\mathrm{X})\end{array}$ & & $\begin{array}{l}\text { Board size }(+), \\
\text { CEO } \\
\text { ownership(-), } \\
\text { firm risk(+) }\end{array}$ & $\begin{array}{l}\text { Fixed salary and share-based } \\
\text { components of compensation are } \\
\text { consistent with efficient contracting } \\
\text { explanations, while bonuses and option } \\
\text { grants are found to be consistent with } \\
\text { rent extraction. }\end{array}$ \\
\hline $\begin{array}{l}\text { Coulton and } \\
\text { Taylor }\end{array}$ & 2002 & $\begin{array}{l}258 \text { ASX firms, } \\
\text { annual report }\end{array}$ & 2000 & $\begin{array}{l}\text { Executive stock } \\
\text { option }\end{array}$ & + & $\begin{array}{l}\text { Prior stock } \\
\text { return(+) }\end{array}$ & Current ROA(-) & $\begin{array}{l}\text { CEO } \\
\text { ownership(-), } \\
\text { insider } \\
\text { ownership(-) }\end{array}$ & $\begin{array}{l}\text { The ratio of options over total pay is } \\
\text { positively associated with firm size and } \\
\text { prior-year return, but negatively related } \\
\text { to current-year ROA, CEO ownership } \\
\text { and insider ownership. The results } \\
\text { indicate that firms with weak corporate } \\
\text { governance are likely to use stock } \\
\text { options excessively. }\end{array}$ \\
\hline $\begin{array}{l}\text { Cybinski and } \\
\text { Windsor }\end{array}$ & 2013 & $\begin{array}{l}143 \text { ASX300 } \\
\text { firms }\end{array}$ & 2001 & $\begin{array}{l}\text { Total cash pay, } \\
\text { and CEO bonus }\end{array}$ & & $\begin{array}{l}\text { Prior-year } \\
\text { ROA }(X)\end{array}$ & & & $\begin{array}{l}\text { The relation between CEO cash pay and } \\
\text { prior-year performance is only } \\
\text { significant in the largest } 50 \text { firms among } \\
\text { ASX300 with an independent } \\
\text { remuneration committee. }\end{array}$ \\
\hline $\begin{array}{l}\text { Doucouliagos, } \\
\text { Haman and } \\
\text { Askary }\end{array}$ & 2007 & $\begin{array}{l}10 \text { Australian } \\
\text { banks, } 149 \text { firm- } \\
\text { years, annual } \\
\text { report }\end{array}$ & $\begin{array}{l}1992- \\
2005\end{array}$ & $\begin{array}{l}\text { Total } \\
\text { compensation }\end{array}$ & + & $\begin{array}{l}\text { Prior bank } \\
\text { performance }(+), \\
\text { prior-year stock } \\
\text { return(+) }\end{array}$ & & $\begin{array}{l}\text { Institutional } \\
\text { ownership(+), } \\
\text { board size(-) }\end{array}$ & $\begin{array}{l}\text { CEO pay is positively related to firm } \\
\text { size, prior-year bank performance, } \\
\text { prior-year stock return and institutional } \\
\text { ownership, but negatively associated } \\
\text { with board size. }\end{array}$ \\
\hline $\begin{array}{l}\text { Heaney, } \\
\text { Tawani and } \\
\text { Goodwin }\end{array}$ & 2010 & $\begin{array}{l}\text { 1,144 listed } \\
\text { Australian firms, } \\
\text { annual report }\end{array}$ & 2006 & $\begin{array}{l}\text { Total } \\
\text { compensation }\end{array}$ & + & $\begin{array}{l}\text { Prior } \\
\text { ROA }(X) \text {,prior } \\
\text { stock return }(X),\end{array}$ & $\begin{array}{l}\text { Current } \\
\text { ROA }(X), \text { current } \\
\text { stock return }(X) \text {, }\end{array}$ & $\begin{array}{l}\text { Board size }(+), \\
\text { growth } \\
\text { option(+), CEO } \\
\text { duality(-) }\end{array}$ & $\begin{array}{l}\text { The level of CEO compensation is } \\
\text { found to be positively related to size, } \\
\text { board size, growth options, and the } \\
\text { separation of CEO and Chairman roles } \\
\text { in the board. However, there is no } \\
\text { evidence of a significant relation } \\
\text { between CEO pay and firm performance } \\
\text { (either accounting or market } \\
\text { performance) in the prior year or future } \\
\text { year. }\end{array}$ \\
\hline
\end{tabular}




\begin{tabular}{|c|c|c|c|c|c|c|c|c|c|}
\hline $\begin{array}{l}\text { Holland, } \\
\text { Dowling and } \\
\text { Innes }\end{array}$ & 2001 & $\begin{array}{l}26 \text { (312) Australia } \\
\text { firms (firm-years) }\end{array}$ & $\begin{array}{l}1988- \\
1999\end{array}$ & $\begin{array}{l}\text { Total } \\
\text { compensation }\end{array}$ & + & & $\begin{array}{l}\text { Current stock } \\
\text { return(+ weak) }\end{array}$ & & $\begin{array}{l}\text { A weak positive relationship between } \\
\text { CEO compensation and current period } \\
\text { market performance, and a strong } \\
\text { positive association between CEO pay } \\
\text { and firm size, which has decreased over } \\
\text { the sample period. }\end{array}$ \\
\hline $\begin{array}{l}\text { Izan H, Sidhu B } \\
\text { and Taylor S }\end{array}$ & 1998 & $\begin{array}{l}99 \text { (488) } \\
\text { Australian firms } \\
\text { (firm-years) with } \\
\text { available financial } \\
\text { and price data, } \\
\text { annual reports }\end{array}$ & $\begin{array}{l}1987- \\
1992\end{array}$ & $\begin{array}{l}\text { Total cash } \\
\text { compensation }\end{array}$ & + & $\begin{array}{l}\text { Prior } \\
\text { ROE(X),prior } \\
\text { stock return }(X),\end{array}$ & $\begin{array}{l}\text { Current } \\
\text { ROE }(X), \text { current } \\
\text { stock return }(X),\end{array}$ & & $\begin{array}{l}\text { They find no evidence of a linkage } \\
\text { between CEO cash pay and current } \\
\text { period performance, as well as prior- } \\
\text { year performance. Firm size is } \\
\text { positively related to CEO pay. } \\
\text { Australian CEOs have had, at least } \\
\text { compared to US CEOs, a relatively } \\
\text { small proportion of total (cash) } \\
\text { compensation 'at risk'. }\end{array}$ \\
\hline Lee & 2009 & $\begin{array}{l}66 \text { Australian } \\
\text { firms, } 47 \\
\text { performance- } \\
\text { improving and } 19 \\
\text { declining, annual } \\
\text { reports }\end{array}$ & 2003 & $\begin{array}{l}\text { Performance- } \\
\text { based pay, } \\
\text { namely bonus } \\
\text { and equity pay }\end{array}$ & + & & $\begin{array}{l}\text { Change in } \\
\mathrm{ROE}(+)\end{array}$ & $\begin{array}{l}\text { CEO duality(+), } \\
\text { CEO change(-), } \\
\text { board } \\
\text { independence } \\
(\mathrm{X})\end{array}$ & $\begin{array}{l}\text { CEO performance-based pay is } \\
\text { positively linked to change in financial } \\
\text { performance, firm size, and CEO } \\
\text { duality, and is likely to reduce in case of } \\
\text { a CEO change. There is no evidence of } \\
\text { an association between performance- } \\
\text { based pay and board independence. }\end{array}$ \\
\hline Matolcsy & 2000 & $\begin{array}{l}100 \text { randomly } \\
\text { selected } \\
\text { Australian firms, } \\
900 \text { firm-years, } \\
\text { annual reports } \\
\end{array}$ & $\begin{array}{l}1987- \\
1995\end{array}$ & $\begin{array}{l}\text { Changes in } \\
\text { total cash-based } \\
\text { compensation }\end{array}$ & & & $\begin{array}{l}\text { Changes in } \\
\text { financial } \\
\text { performance } \\
\text { (mixed) }\end{array}$ & & $\begin{array}{l}\text { The relationship between changes in } \\
\text { CEO cash compensation and changes in } \\
\text { financial performance is positive during } \\
\text { economic growth, but is flat during an } \\
\text { economic downturn. }\end{array}$ \\
\hline $\begin{array}{l}\text { Matolcsy and } \\
\text { Wright }\end{array}$ & 2006 & $\begin{array}{l}696 \text { firm-years } \\
\text { from top } 500 \\
\text { Australian firms, } \\
\text { Sirca Limited }\end{array}$ & $\begin{array}{l}1999- \\
2001\end{array}$ & $\begin{array}{l}\text { Total } \\
\text { compensation }\end{array}$ & + & & $\begin{array}{l}\text { Current stock } \\
\text { return(+) }\end{array}$ & $\begin{array}{l}\text { Firm } \\
\text { complexity }(+)\end{array}$ & $\begin{array}{l}\text { Levels of Australian CEO compensation } \\
\text { are associated with the firm's } \\
\text { underlying economic characteristics, } \\
\text { with a positive relation to firm size, firm } \\
\text { complexity and current stock price } \\
\text { performance. }\end{array}$ \\
\hline $\begin{array}{l}\text { Matolcsy and } \\
\text { Wright }\end{array}$ & 2007 & $\begin{array}{l}696 \text { firm-years } \\
\text { from top } 500 \\
\text { Australian firms, } \\
\text { Sirca Limited }\end{array}$ & $\begin{array}{l}1999- \\
2001\end{array}$ & $\begin{array}{l}\text { Total } \\
\text { compensation, } \\
\text { cash and } \\
\text { equity-based } \\
\text { pay }\end{array}$ & + & & & & $\begin{array}{l}\text { Finds } 34 \% \text { firm-years with only cash } \\
\text { pay and } 66 \% \text { firm-years where a } \\
\text { combination of cash- and equity-based } \\
\text { compensation is paid. CEO pay is } \\
\text { highest in the banking and finance } \\
\text { sector, but the pay levels are much } \\
\text { lower than US CEOs. }\end{array}$ \\
\hline $\begin{array}{l}\text { Merhebi, } \\
\text { Pattenden, } \\
\text { Swan and Zhou }\end{array}$ & 2006 & $\begin{array}{l}722(2,574) \text { firms } \\
\text { (firm-years) from } \\
\text { the Top } 500 \text { firms } \\
\text { listed in Business }\end{array}$ & $\begin{array}{l}1990- \\
1999\end{array}$ & $\begin{array}{l}\text { Total cash } \\
\text { compensation }\end{array}$ & + & & $\begin{array}{l}\text { Current } \\
\text { ROA }(X), \\
\text { current stock } \\
\text { return }(X),\end{array}$ & & $\begin{array}{l}\text { CEO pay is positively related to firm } \\
\text { size, but is not related to } \\
\text { contemporaneous accounting and } \\
\text { market performance. }\end{array}$ \\
\hline
\end{tabular}




\begin{tabular}{|c|c|c|c|c|c|c|c|c|}
\hline & & $\begin{array}{l}\text { Review Weekly, } \\
\text { annual reports }\end{array}$ & & & & & & \\
\hline O'Neill and Iob & 1999 & $\begin{array}{l}49 \text { firms from top } \\
150 \text { Australian } \\
\text { firms, annual } \\
\text { reports }\end{array}$ & 1997 & $\begin{array}{l}\text { Salary and total } \\
\text { pay }\end{array}$ & + & $\begin{array}{l}\text { Accounting } \\
\text { performance }(X)\end{array}$ & $\begin{array}{l}\text { CEO age }(X), \\
\text { CEO service } \\
\text { years }(X)\end{array}$ & $\begin{array}{l}\text { The level of CEO base salary and total } \\
\text { pay is positively related to size, but is } \\
\text { not associated with firm performance, } \\
\text { CEO age and the number of CEO } \\
\text { service years. }\end{array}$ \\
\hline $\begin{array}{l}\text { Schultz, Tian } \\
\text { and Twite }\end{array}$ & 2013 & $\begin{array}{l}\text { 8,594 firm-years } \\
\text { with available } \\
\text { compensation } \\
\text { data, Boardroom }\end{array}$ & $\begin{array}{l}2000- \\
2010\end{array}$ & $\begin{array}{l}\text { Total } \\
\text { compensation, } \\
\text { known pay, } \\
\text { cash bonus and } \\
\text { long-term at- } \\
\text { risk pay }\end{array}$ & + & $\begin{array}{l}\text { Current } \\
\operatorname{ROA}(+)\end{array}$ & $\begin{array}{l}\text { Tobin } \mathrm{Q}(+), \\
\text { leverage(-), } \\
\text { Board size(+), } \\
\text { CEO duality(-), } \\
\text { the ratio of } \\
\text { nonexecutive } \\
\text { directors (+), the } \\
\text { existence of } \\
\text { remuneration } \\
\text { committee(+), } \\
\text { CEO serving the } \\
\text { remuneration } \\
\text { committee(-) }\end{array}$ & $\begin{array}{l}\text { There is no evidence of a consistent } \\
\text { relationship between the effectiveness } \\
\text { of board monitoring activity and levels } \\
\text { of CEO compensation. Results also } \\
\text { highlight the role of blockholders } \\
\text { (outside and insider) in affecting the } \\
\text { pay-performance sensitivity. }\end{array}$ \\
\hline Walker & 2010 & $\begin{array}{l}50 \text { randomly } \\
\text { selected 'high- } \\
\text { growth' and } 50 \\
\text { 'low-growth' } \\
\text { firms, annual } \\
\text { reports } \\
\end{array}$ & $\begin{array}{l}2005- \\
2006\end{array}$ & $\begin{array}{l}\text { Performance- } \\
\text { based pay and } \\
\text { equity pay }\end{array}$ & + & $\begin{array}{l}\text { Current } \\
\text { ROA }(X)\end{array}$ & $\begin{array}{l}\text { Growth(+), CEO } \\
\text { ownership }(X), \\
\text { CEO duality }(X)\end{array}$ & $\begin{array}{l}\text { Performance-based pay is positively } \\
\text { related to firm size and growth, but is } \\
\text { not significantly associated with ROA, } \\
\text { CEO ownership and CEO duality. }\end{array}$ \\
\hline
\end{tabular}


Table 8: Australian empirical studies on the CEO pay-performance sensitivity

\begin{tabular}{|c|c|c|c|c|c|c|}
\hline Authors & Year & Sample/Sources & $\begin{array}{l}\text { Sample } \\
\text { year }\end{array}$ & Pay measures & Pay-performance sensitivity & Key findings \\
\hline $\begin{array}{l}\text { Clarkson, Walker } \\
\text { and Nicholls }\end{array}$ & 2011 & $\begin{array}{l}240(2,160) \text { firms (firm- } \\
\text { years) available in each } \\
\text { year of 2001-2009, annual } \\
\text { report }\end{array}$ & $\begin{array}{l}2001- \\
2009\end{array}$ & $\begin{array}{l}\text { Total } \\
\text { compensation, } \\
\text { salary, bonus and } \\
\text { equity pay }\end{array}$ & $\begin{array}{l}\text { A general improvement in pay- } \\
\text { performance sensitivity over } 2001- \\
2009 \text {. The sensitivity increase is } \\
\text { primarily related to enhanced } \\
\text { remuneration disclosure and the non- } \\
\text { binding shareholder vote on the } \\
\text { remuneration report. }\end{array}$ & $\begin{array}{l}\text { Enhanced oversight over executive remuneration } \\
\text { arrangements resulting from regulatory change } \\
\text { has a positive impact on the process of executive } \\
\text { compensation arrangement by strengthening } \\
\text { pay-performance sensitivity }\end{array}$ \\
\hline $\begin{array}{l}\text { Izan H, Sidhu B } \\
\text { and Taylor S }\end{array}$ & 1998 & $\begin{array}{l}99 \text { (488) Australian firms } \\
\text { (firm-years) with available } \\
\text { financial and price data, } \\
\text { annual reports }\end{array}$ & $\begin{array}{l}1987- \\
1992\end{array}$ & $\begin{array}{l}\text { Total cash } \\
\text { compensation }\end{array}$ & $\begin{array}{l}\text { Preliminary evidence on pay- } \\
\text { performance sensitivity for total cash } \\
\text { compensation shows that the } \\
\text { sensitivity is close to zero. }\end{array}$ & $\begin{array}{l}\text { Australian CEOs have had, at least compared to } \\
\text { US CEOs, a relatively small proportion of total } \\
\text { (cash) compensation 'at risk'. }\end{array}$ \\
\hline $\begin{array}{l}\text { Merhebi, } \\
\text { Pattenden, Swan } \\
\text { and Zhou }\end{array}$ & 2006 & $\begin{array}{l}722(2,574) \text { firms (firm- } \\
\text { years) from ASX Top } 500 \\
\text { firms listed in Business } \\
\text { Review Weekly, annual } \\
\text { reports }\end{array}$ & $\begin{array}{l}1990- \\
1999\end{array}$ & $\begin{array}{l}\text { Total cash } \\
\text { compensation }\end{array}$ & $\begin{array}{l}\text { Changes in CEO cash pay is positively } \\
\text { associated with the change in current } \\
\text { and lagged period shareholder wealth } \\
\text { (a CEO receives a } 1.16 \text { per cent } \\
\text { increase in pay for a } 10 \text { per cent } \\
\text { increase in shareholder wealth). }\end{array}$ & $\begin{array}{l}\text { Pay-performance sensitivity and elasticity are } \\
\text { positive and significant. CEO pay sensitivity } \\
\text { decreases as the riskiness of the firm increases. } \\
\text { The results are consistent with efficient } \\
\text { contracting explanation. }\end{array}$ \\
\hline Monem and $\mathrm{Ng}$ & 2013 & $\begin{array}{l}104 \text { firms in } 2011 \text { and } 105 \\
\text { firms in } 2012 \text { that } \\
\text { experience 'first strike', } \\
\text { Boardroom }\end{array}$ & $\begin{array}{l}2011- \\
2012\end{array}$ & $\begin{array}{l}\text { Total } \\
\text { compensation }\end{array}$ & $\begin{array}{l}\text { There is no difference in pay- } \\
\text { performance sensitivity between the } \\
\text { 'first strike' firms and the control } \\
\text { firms. The shareholder voting power } \\
\text { has little impact on the pay- } \\
\text { performance sensitivity. }\end{array}$ & $\begin{array}{l}\text { The pay-performance sensitivity is not } \\
\text { significant for firms that experience a 'first } \\
\text { strike' in } 2011 \text { under the 'two-strikes' rule. } \\
\text { However, the relations improved in } 2012 \text {. The } \\
\text { results suggest that the shareholders of the 'first- } \\
\text { strike' firms may have been over-enthusiastic } \\
\text { about their voting power in } 2011 \text { but exercised } \\
\text { this power more judiciously in } 2012 \text {. }\end{array}$ \\
\hline $\begin{array}{l}\text { Schultz, Tian and } \\
\text { Twite }\end{array}$ & 2013 & $\begin{array}{l}8,594 \text { firm-years with } \\
\text { available compensation } \\
\text { data, Boardroom }\end{array}$ & $\begin{array}{l}2000- \\
2010\end{array}$ & $\begin{array}{l}\text { Total } \\
\text { compensation, } \\
\text { known pay, cash } \\
\text { bonus and long- } \\
\text { term at-risk pay }\end{array}$ & $\begin{array}{l}\text { The sensitivity of long-term at-risk } \\
\text { pay increases with monitoring } \\
\text { blockholders, but decrease with insider } \\
\text { blockholders and board size. The } \\
\text { sensitivity of cash bonuses increases } \\
\text { with insider blockholders, and the } \\
\text { sensitivity of known pay decreases } \\
\text { with board size. }\end{array}$ & $\begin{array}{l}\text { Results highlight the role of blockholders } \\
\text { (outside and insider) in affecting the pay- } \\
\text { performance sensitivity. Monitoring } \\
\text { blockholders better align manager and } \\
\text { shareholder interests, while insider blockholders } \\
\text { have a shorter investment horizon and prefer } \\
\text { short-term pay. Larger boards are found to be } \\
\text { less effective monitors. }\end{array}$ \\
\hline
\end{tabular}


Table 9: Australian empirical studies on the effect of CEO pay on firm performance and corporate actions

\begin{tabular}{|c|c|c|c|c|c|c|}
\hline Authors & Year & Sample/Sources & $\begin{array}{l}\text { Sample } \\
\text { year }\end{array}$ & Incentive measures & $\begin{array}{l}\text { Corporate } \\
\text { outcome }\end{array}$ & Incentive effect and findings \\
\hline $\begin{array}{l}\text { Bugeja, da Silva Rosa } \\
\text {, Duong and Izan }\end{array}$ & 2012 & $\begin{array}{l}\text { Acquiring and target } \\
\text { firms in } 177 \mathrm{M} \& \mathrm{~A} \\
\text { deals, Boardroom and } \\
\text { annual reports }\end{array}$ & $\begin{array}{l}2000- \\
2007\end{array}$ & $\begin{array}{l}\text { Total compensation, } \\
\text { salary, bonus, shares and } \\
\text { options }\end{array}$ & Takeovers & $\begin{array}{l}\text { All components of CEO compensation increase in the M\&A } \\
\text { completion year and the subsequent year, but target CEOs } \\
\text { receive lower compensation if they are on the nominating } \\
\text { committee, or have higher ownership, or the board has higher } \\
\text { proportion of insiders. Results are more consistent with } \\
\text { efficient contracting. }\end{array}$ \\
\hline Li, Henry and Chou & 2011 & $\begin{array}{l}\text { 1,471 firm-years with } \\
\text { available data, } \\
\text { Boardroom }\end{array}$ & $\begin{array}{l}2004- \\
2007\end{array}$ & $\begin{array}{l}\text { Total equity-based pay to } \\
\text { all executives and } \\
\text { directors relative to total } \\
\text { compensation or market } \\
\text { value of equity }\end{array}$ & $\begin{array}{l}\text { Investment } \\
\text { level }\end{array}$ & $\begin{array}{l}\text { There is a significant positive relation between corporate } \\
\text { investment level and equity-based compensation relative to } \\
\text { market value of equity, but the relation is not significant when } \\
\text { equity-based compensation is measured as a ratio of total } \\
\text { compensation. The results suggest that managers make } \\
\text { investment decisions that concern their equity-based } \\
\text { compensation. }\end{array}$ \\
\hline Matolcsy and Wright & 2011 & $\begin{array}{l}\text { 3,503 firm-years for } \\
\text { top 500 Australian } \\
\text { firms, Sirca Limited }\end{array}$ & $\begin{array}{l}1999- \\
2005\end{array}$ & $\begin{array}{l}\text { Cash-based or equity- } \\
\text { based compensation group }\end{array}$ & $\begin{array}{l}\text { Financial } \\
\text { and stock } \\
\text { price } \\
\text { performance }\end{array}$ & $\begin{array}{l}\text { Firms that adopt CEO compensation structures that deviate } \\
\text { from the 'efficient compensation structure' (i.e., the incorrect } \\
\text { group membership in either cash or equity compensation) have } \\
\text { lower accounting and market performance than firms that have } \\
\text { an efficient structure. }\end{array}$ \\
\hline
\end{tabular}


Table 10: Sharemarket estimates of shareholder wealth creation of four ASX listed companies during the tenure of their former CEO estimated using (i) the CAPM, (ii) the Market Model, (iii) Fama-French three-factor model, and (iv) the Carhart four-factor model.

Panel A: Without accounting for dividend imputation franking credits

\begin{tabular}{|c|c|c|c|c|c|c|}
\hline $\begin{array}{l}\text { Company and } \\
\text { CEO }\end{array}$ & $\begin{array}{l}\text { Telstra Corporation } \\
\text { Trujillo, Solomon }\end{array}$ & $\begin{array}{c}\text { Air New Zealand } \\
\text { Fyfe, Robert } \\
\end{array}$ & $\begin{array}{l}\text { Caltex Australia } \\
\text { Reeves, David }\end{array}$ & $\begin{array}{l}\text { QGC Pty Limited } \\
\text { Cottee, Richard }\end{array}$ & $\begin{array}{c}\text { Mirvac Group } \\
\text { Paramor, Gregory }\end{array}$ & $\begin{array}{l}\text { Clough Limited } \\
\text { Singleton, David }\end{array}$ \\
\hline \multicolumn{7}{|l|}{ CAPM } \\
\hline Alpha & $-0.49 \%$ & $0.49 \%$ & $4.44 \%$ & $5.29 \%$ & $-1.37 \%$ & $-2.72 \%$ \\
\hline$t$-statistic $(\alpha=0)$ & -0.63 & 0.50 & $2.26^{* *}$ & $2.69 * * *$ & -1.17 & $-1.79 * *$ \\
\hline \multicolumn{7}{|l|}{ Market Model } \\
\hline Alpha & $-0.16 \%$ & $0.52 \%$ & $4.50 \%$ & $5.48 \%$ & $-1.38 \%$ & $-2.79 \%$ \\
\hline$t$-statistic $(\alpha=0)$ & -0.21 & 0.53 & $2.07^{* *}$ & $2.73 * * *$ & -1.15 & $-1.67^{*}$ \\
\hline \multicolumn{7}{|l|}{$\begin{array}{l}\text { Fama-French } \\
\text { Three-factor } \\
\text { model }\end{array}$} \\
\hline Alpha & $-0.65 \%$ & $0.18 \%$ & $5.22 \%$ & $5.46 \%$ & $-1.35 \%$ & $-2.65 \%$ \\
\hline$t$-statistic $(\alpha=0)$ & -0.82 & 0.19 & $2.38^{* *}$ & $2.85^{* * *}$ & -1.19 & $-1.58 *$ \\
\hline \multicolumn{7}{|l|}{$\begin{array}{l}\text { Carhart Four- } \\
\text { factor model }\end{array}$} \\
\hline Alpha & $-0.60 \%$ & $0.18 \%$ & $5.31 \%$ & $5.00 \%$ & $-1.62 \%$ & $-2.65 \%$ \\
\hline$t$-statistic $(\alpha=0)$ & -0.75 & 0.19 & $2.36^{* *}$ & $2.41^{* *}$ & -1.27 & $-1.53^{*}$ \\
\hline
\end{tabular}

${ }^{*}$ significant at 10 per cent; ${ }^{* *}$ significant at 5 per cent; ${ }^{* * *}$ significant at 1 per cent 
Panel B: Accounting for dividend imputation franking credits

\begin{tabular}{|c|c|c|c|c|c|c|}
\hline $\begin{array}{l}\text { Company and } \\
\text { CEO }\end{array}$ & $\begin{array}{l}\text { Telstra Corporation } \\
\text { Trujillo, Solomon }\end{array}$ & $\begin{array}{c}\text { Air New Zealand } \\
\text { Fyfe, Robert }\end{array}$ & $\begin{array}{l}\text { Caltex Australia } \\
\text { Reeves, David }\end{array}$ & $\begin{array}{l}\text { QGC Pty Limited } \\
\text { Cottee, Richard }\end{array}$ & $\begin{array}{c}\text { Mirvac Group } \\
\text { Paramor, Gregory }\end{array}$ & $\begin{array}{l}\text { Clough Limited } \\
\text { Singleton, David }\end{array}$ \\
\hline \multicolumn{7}{|l|}{ CAPM } \\
\hline Alpha & $-0.24 \%$ & $0.39 \%$ & $4.48 \%$ & $5.23 \%$ & $-1.41 \%$ & $-2.85 \%$ \\
\hline$t$-statistic $(\alpha=0)$ & -0.32 & 0.40 & $2.22 * *$ & $2.65 * * *$ & -1.19 & $-1.84^{* *}$ \\
\hline \multicolumn{7}{|l|}{ Market Model } \\
\hline Alpha & $0.08 \%$ & $0.43 \%$ & $4.53 \%$ & $5.43 \%$ & $-1.42 \%$ & $-2.92 \%$ \\
\hline$t$-statistic $(\alpha=0)$ & 0.10 & 0.43 & $2.04^{* *}$ & $2.69 * * *$ & -1.17 & $-1.72 *$ \\
\hline \multicolumn{7}{|l|}{$\begin{array}{l}\text { Fama-French } \\
\text { Three-factor } \\
\text { model }\end{array}$} \\
\hline Alpha & $-0.36 \%$ & $0.09 \%$ & $5.27 \%$ & $5.44 \%$ & $-1.41 \%$ & $-2.77 \%$ \\
\hline$t$-statistic $(\alpha=0)$ & -0.47 & 0.09 & $2.35 * *$ & $2.83 * * *$ & -1.24 & $-1.62^{*}$ \\
\hline \multicolumn{7}{|l|}{$\begin{array}{l}\text { Carhart Four- } \\
\text { factor model }\end{array}$} \\
\hline Alpha & $-0.31 \%$ & $0.09 \%$ & $5.35 \%$ & $4.99 \%$ & $-1.69 \%$ & $-2.78 \%$ \\
\hline$t$-statistic $(\alpha=0)$ & -0.39 & 0.10 & $2.32 * *$ & $2.40^{* *}$ & -1.32 & $-1.58^{*}$ \\
\hline
\end{tabular}

* significant at 10 per cent; ${ }^{* *}$ significant at 5 per cent; ${ }^{* * *}$ significant at 1 per cent 
Table 11: Summary statistics of the alpha estimated from different models over the period of time during which the CEOs were in that position

Panel A: All CEOs

\begin{tabular}{|l|c|c|c|c|}
\hline & CAPM & Market model & $\begin{array}{c}\text { Fama-French } \\
\text { three-factor model }\end{array}$ & $\begin{array}{c}\text { Carhart four- } \\
\text { factor model }\end{array}$ \\
\hline $\mathrm{N}$ & 589 & 589 & 589 & 589 \\
\hline Mean & 0.0003 & -0.0010 & -0.0036 & -0.0026 \\
\hline Median & 0.0009 & 0.0004 & -0.0015 & -0.0014 \\
\hline Standard deviation & 0.0362 & 0.0360 & 0.0413 & 0.0433 \\
\hline Q1 & -0.0170 & -0.0179 & -0.0216 & -0.0222 \\
\hline Q3 & 0.0147 & 0.0145 & 0.0132 & 0.0128 \\
\hline obs(Positive) & 310 & 301 & 272 & 276 \\
\hline \% Positive & $52.6 \%$ & $51.1 \%$ & $46.2 \%$ & $46.9 \%$ \\
\hline obs(Negative) & 279 & 288 & 317 & 313 \\
\hline \% Negative & $47.4 \%$ & $48.9 \%$ & $53.8 \%$ & $53.1 \%$ \\
\hline obs(sig positive) & 72 & 68 & 54 & 53 \\
\hline \% Sig positive & $12.2 \%$ & $11.5 \%$ & $9.2 \%$ & $9.0 \%$ \\
\hline obs(sig negative) & 56 & 58 & 72 & 66 \\
\hline \% Sig negative & $9.5 \%$ & $9.8 \%$ & $12.2 \%$ & $11.2 \%$ \\
\hline
\end{tabular}

Panel B: All CEOs (accounting for dividend imputation franking credits)

\begin{tabular}{|l|c|c|c|c|}
\hline & CAPM & Market model & $\begin{array}{c}\text { Fama-French } \\
\text { three-factor model }\end{array}$ & $\begin{array}{c}\text { Carhart four- } \\
\text { factor model }\end{array}$ \\
\hline $\mathrm{N}$ & 589 & 589 & 589 & 589 \\
\hline Mean & -0.0004 & -0.0017 & -0.0042 & -0.0031 \\
\hline Median & 0.0006 & 0.0005 & -0.0017 & -0.0020 \\
\hline Standard deviation & 0.0362 & 0.0360 & 0.0413 & 0.0433 \\
\hline Q1 & -0.0174 & -0.0191 & -0.0229 & -0.0232 \\
\hline Q3 & 0.0143 & 0.0146 & 0.0132 & 0.0136 \\
\hline obs(Positive) & 301 & 299 & 270 & 274 \\
\hline$\%$ Positive & $51.1 \%$ & $50.8 \%$ & $45.8 \%$ & $46.5 \%$ \\
\hline obs(Negative) & 288 & 290 & 319 & 315 \\
\hline$\%$ Negative & $48.9 \%$ & $49.2 \%$ & $54.2 \%$ & $53.5 \%$ \\
\hline obs(sig positive) & 74 & 64 & 56 & 56 \\
\hline \% Sig positive & $12.6 \%$ & $10.9 \%$ & $9.5 \%$ & $9.5 \%$ \\
\hline obs(sig negative) & 61 & 58 & 74 & 66 \\
\hline$\%$ Sig negative & $10.4 \%$ & $9.8 \%$ & $12.6 \%$ & $11.2 \%$ \\
\hline
\end{tabular}


Table 12: Summary statistics of the alpha estimated from different models over the period of time during which the CEOs were in that position

Panel A: CEOs who had been in the position for more than three years

\begin{tabular}{|l|c|c|c|c|}
\hline & CAPM & Market model & $\begin{array}{c}\text { Fama-French } \\
\text { three-factor model }\end{array}$ & $\begin{array}{c}\text { Carhart four- } \\
\text { factor model }\end{array}$ \\
\hline $\mathrm{N}$ & 321 & 321 & 321 & 321 \\
\hline Mean & 0.0063 & 0.0051 & 0.0020 & 0.0024 \\
\hline Median & 0.0030 & 0.0032 & 0.0010 & 0.0015 \\
\hline Standard deviation & 0.0266 & 0.0264 & 0.0260 & 0.0254 \\
\hline Q1 & -0.0056 & -0.0072 & -0.0110 & -0.0090 \\
\hline Q3 & 0.0160 & 0.0149 & 0.0129 & 0.0119 \\
\hline obs(Positive) & 196 & 190 & 171 & 174 \\
\hline \% Positive & $61.1 \%$ & $59.2 \%$ & $53.3 \%$ & $54.2 \%$ \\
\hline obs(Negative) & 125 & 131 & 150 & 147 \\
\hline$\%$ Negative & $38.9 \%$ & $40.8 \%$ & $46.7 \%$ & $45.8 \%$ \\
\hline obs(sig positive) & 53 & 50 & 37 & 36 \\
\hline$\%$ Sig positive & $16.5 \%$ & $15.6 \%$ & $11.5 \%$ & $11.2 \%$ \\
\hline obs(sig negative) & 20 & 21 & 28 & 26 \\
\hline$\%$ Sig negative & $6.2 \%$ & $6.5 \%$ & $8.7 \%$ & $8.1 \%$ \\
\hline
\end{tabular}

Panel B: CEOs who had been in the position for less than three years

\begin{tabular}{|l|c|c|c|c|}
\hline & CAPM & Market model & $\begin{array}{c}\text { Fama-French } \\
\text { three-factor model }\end{array}$ & $\begin{array}{c}\text { Carhart four- } \\
\text { factor model }\end{array}$ \\
\hline $\mathrm{N}$ & 268 & 268 & 268 & 268 \\
\hline Mean & -0.0069 & -0.0084 & -0.0103 & -0.0085 \\
\hline Median & -0.0054 & -0.0067 & -0.0082 & -0.0108 \\
\hline Standard deviation & 0.0441 & 0.0437 & 0.0534 & 0.0573 \\
\hline Q1 & -0.0288 & -0.0307 & -0.0407 & -0.0377 \\
\hline Q3 & 0.0137 & 0.0120 & 0.0160 & 0.0175 \\
\hline obs(Positive) & 114 & 111 & 101 & 102 \\
\hline$\%$ Positive & $42.5 \%$ & $41.4 \%$ & $37.7 \%$ & $38.1 \%$ \\
\hline obs(Negative) & 154 & 157 & 167 & 166 \\
\hline$\%$ Negative & $57.5 \%$ & $58.6 \%$ & $62.3 \%$ & $61.9 \%$ \\
\hline obs(sig positive) & 19 & 18 & 17 & 17 \\
\hline$\%$ Sig positive & $7.1 \%$ & $6.7 \%$ & $6.3 \%$ & $6.3 \%$ \\
\hline obs(sig negative) & 36 & 37 & 44 & 40 \\
\hline$\%$ Sig negative & $13.4 \%$ & $13.8 \%$ & $16.4 \%$ & $14.9 \%$ \\
\hline
\end{tabular}


Panel C: CEOs who had been in the position for more than three years (accounting for dividend imputation franking credits)

\begin{tabular}{|l|c|c|c|c|}
\hline & CAPM & Market model & $\begin{array}{c}\text { Fama-French } \\
\text { three-factor model }\end{array}$ & $\begin{array}{c}\text { Carhart four- } \\
\text { factor model }\end{array}$ \\
\hline $\mathrm{N}$ & 321 & 321 & 321 & 321 \\
\hline Mean & 0.0057 & 0.0045 & 0.0015 & 0.0019 \\
\hline Median & 0.0027 & 0.0029 & 0.0005 & 0.0011 \\
\hline Standard deviation & 0.0265 & 0.0265 & 0.0260 & 0.0254 \\
\hline Q1 & -0.0067 & -0.0082 & -0.0123 & -0.0099 \\
\hline Q3 & 0.0149 & 0.0152 & 0.0128 & 0.0123 \\
\hline obs(Positive) & 189 & 186 & 168 & 174 \\
\hline$\%$ Positive & $58.9 \%$ & $57.9 \%$ & $52.3 \%$ & $54.2 \%$ \\
\hline obs(Negative) & 132 & 135 & 153 & 147 \\
\hline$\%$ Negative & $41.1 \%$ & $42.1 \%$ & $47.7 \%$ & $45.8 \%$ \\
\hline obs(sig positive) & 54 & 47 & 41 & 39 \\
\hline \% Sig positive & $16.8 \%$ & $14.6 \%$ & $12.8 \%$ & $12.1 \%$ \\
\hline obs(sig negative) & 23 & 22 & 28 & 27 \\
\hline \% Sig negative & $7.2 \%$ & $6.9 \%$ & $8.7 \%$ & $8.4 \%$ \\
\hline
\end{tabular}

Panel D: CEOs who had been in the position for less than three years (accounting for dividend imputation franking credits)

\begin{tabular}{|l|c|c|c|c|}
\hline & CAPM & Market model & $\begin{array}{c}\text { Fama-French } \\
\text { three-factor model }\end{array}$ & $\begin{array}{c}\text { Carhart four- } \\
\text { factor model }\end{array}$ \\
\hline $\mathrm{N}$ & 268 & 268 & 268 & 268 \\
\hline Mean & -0.0077 & -0.0091 & -0.0110 & -0.0091 \\
\hline Median & -0.0060 & -0.0077 & -0.0091 & -0.0110 \\
\hline Standard deviation & 0.0440 & 0.0438 & 0.0535 & 0.0574 \\
\hline Q1 & -0.0302 & -0.0315 & -0.0409 & -0.0388 \\
\hline Q3 & 0.0130 & 0.0120 & 0.0146 & 0.0170 \\
\hline obs(Positive) & 112 & 113 & 102 & 100 \\
\hline$\%$ Positive & $41.8 \%$ & $42.2 \%$ & $38.1 \%$ & $37.3 \%$ \\
\hline obs(Negative) & 156 & 155 & 166 & 168 \\
\hline$\%$ Negative & $58.2 \%$ & $57.8 \%$ & $61.9 \%$ & $62.7 \%$ \\
\hline obs(sig positive) & 20 & 17 & 15 & 17 \\
\hline \% Sig positive & $7.5 \%$ & $6.3 \%$ & $5.6 \%$ & $6.3 \%$ \\
\hline obs(sig negative) & 38 & 36 & 46 & 39 \\
\hline$\%$ Sig negative & $14.2 \%$ & $13.4 \%$ & $17.2 \%$ & $14.6 \%$ \\
\hline
\end{tabular}


Figure 1.Mean and median CEO compensation for all firms included in the Sirca Limited corporate governance database for 2001 to 2012, where all dollar values are adjusted to December 2012 dollars using the Australian CPI.

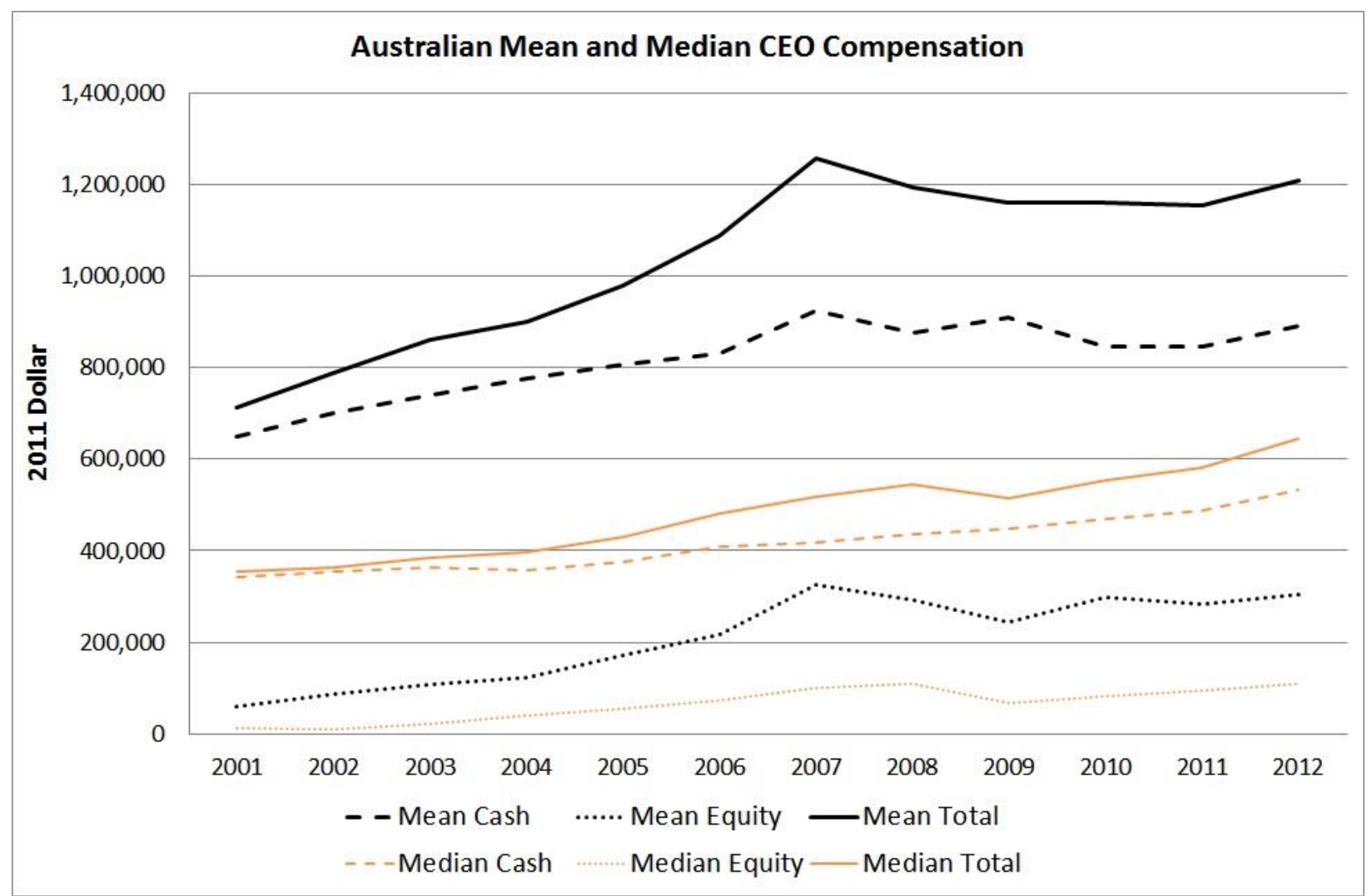


Figure 2.Mean and median CEO compensation for Top 100 firms included in the Sirca Limited corporate governance database for 2001 to 2012, where all dollar values are adjusted to December 2012 dollars using the Australian CPI.

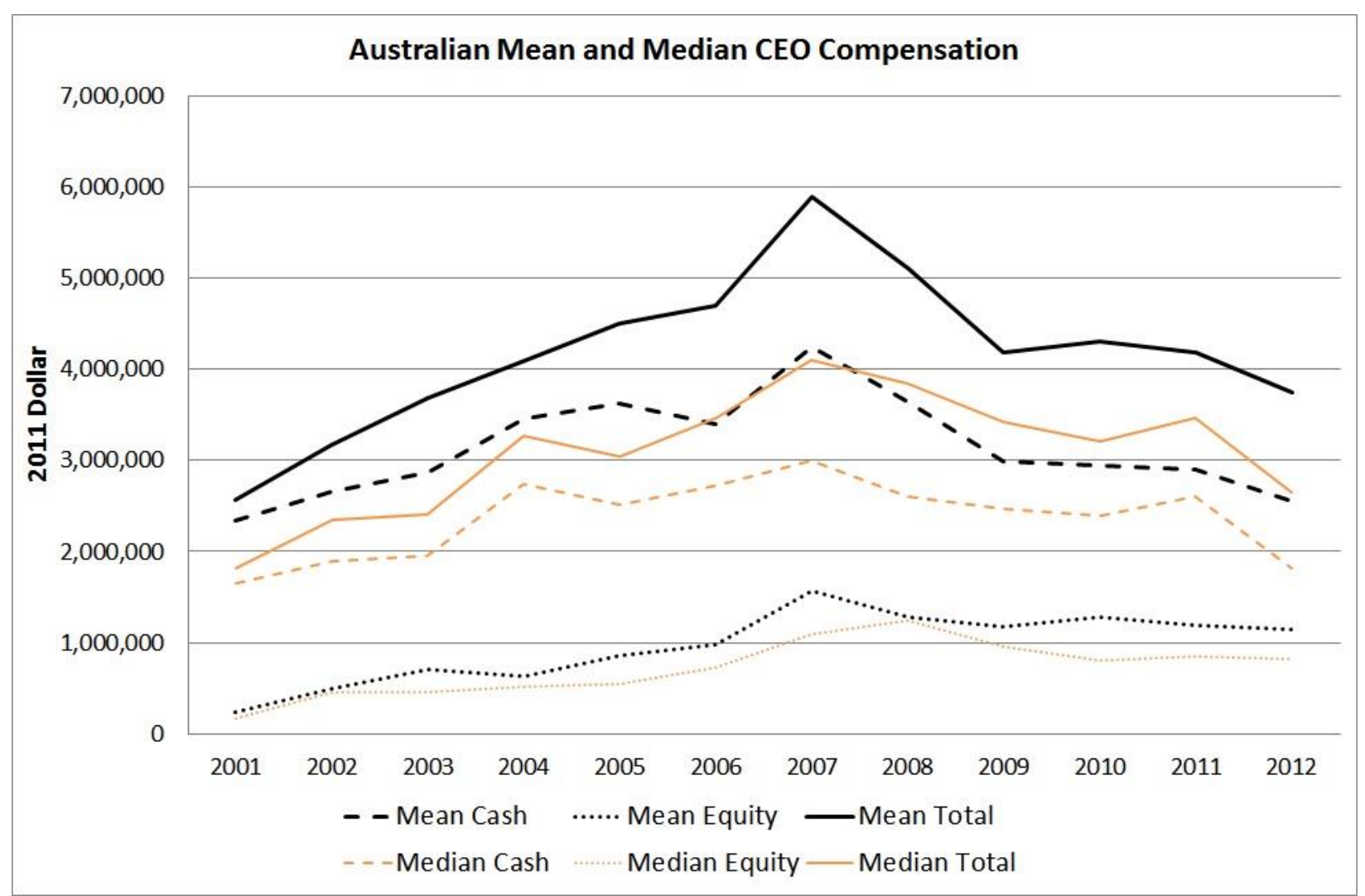


Figure 3.Mean and median CEO compensation for Top 200 firms included in the Sirca Limited corporate governance database for 2001 to 2012, where all dollar values are adjusted to December 2012 dollars using the Australian CPI.

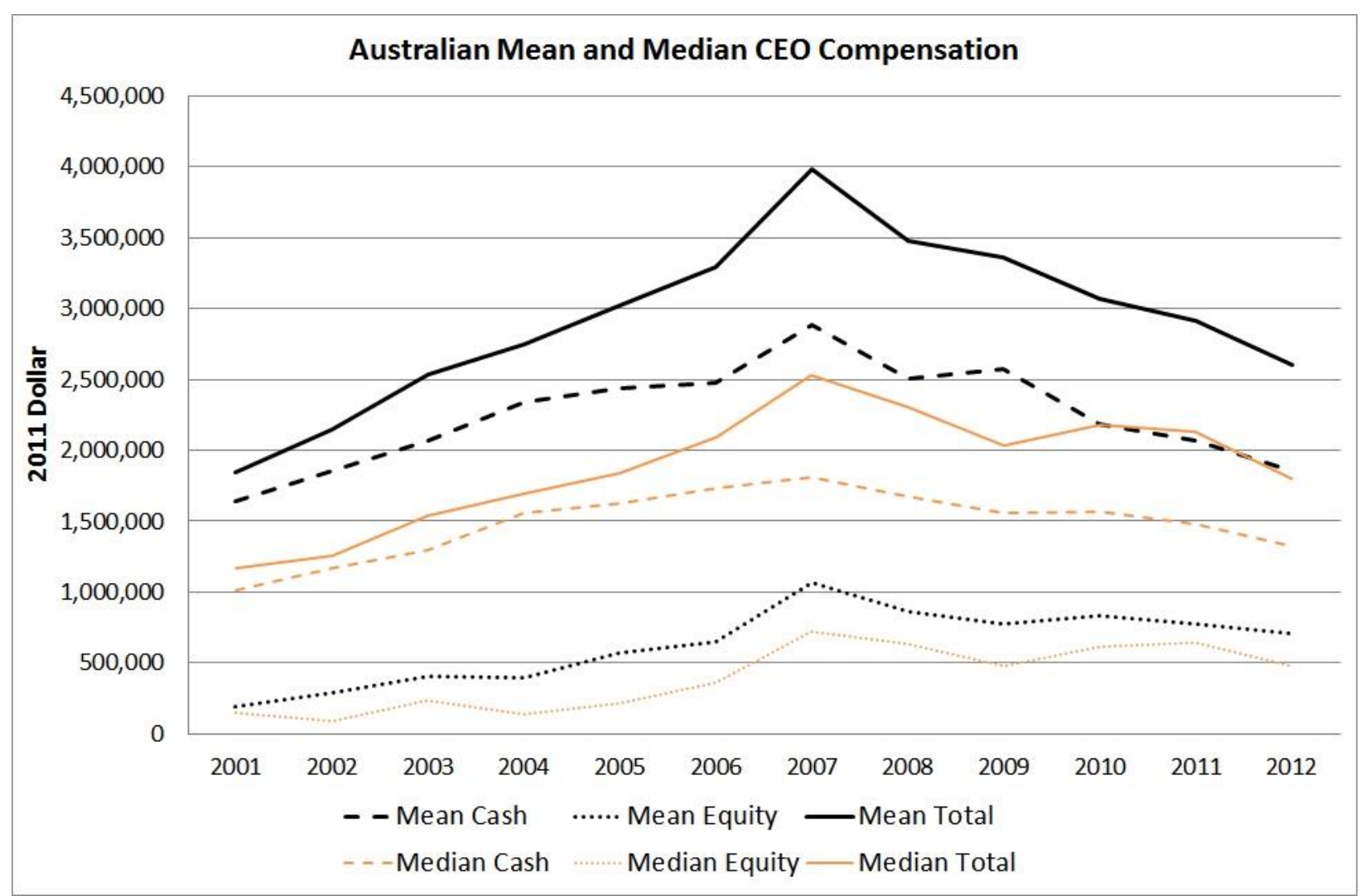


Figure 4.Mean and median CEO compensation for Top 300 firms included in the Sirca Limited corporate governance database for 2001 to 2012, where all dollar values are adjusted to December 2012 dollars using the Australian CPI.

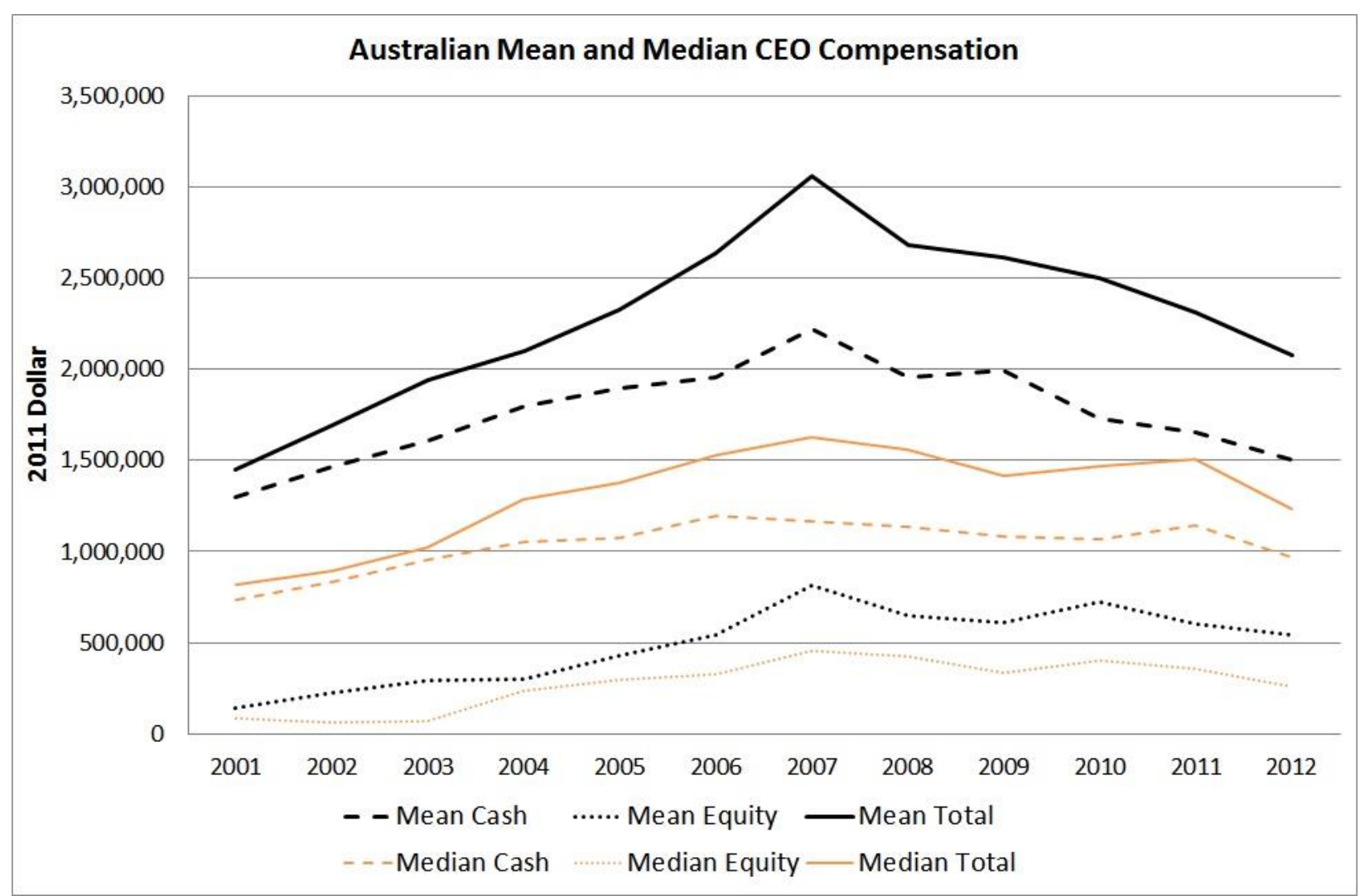


Figure 3.Mean and median CEO compensation for Top 101-300 firms included in the Sirca Limited corporate governance database for 2001 to 2012, where all dollar values are adjusted to December 2012 dollars using the Australian CPI.

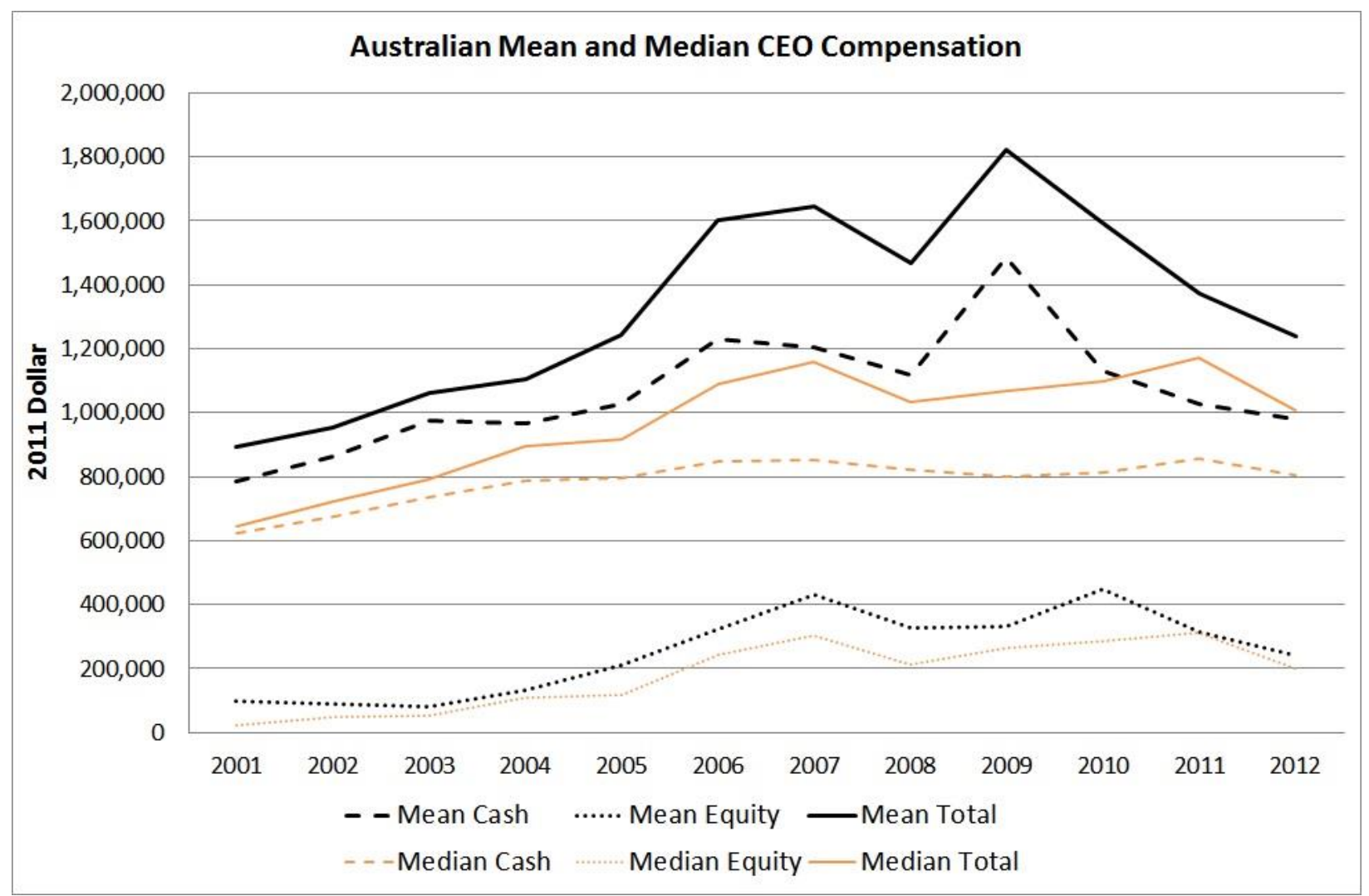


Figure 6.Mean and median CEO compensation for Non Top 300 firms included in the Sirca Limited corporate governance database for 2001 to 2012, where all dollar values are adjusted to December 2012 dollars using the Australian CPI.

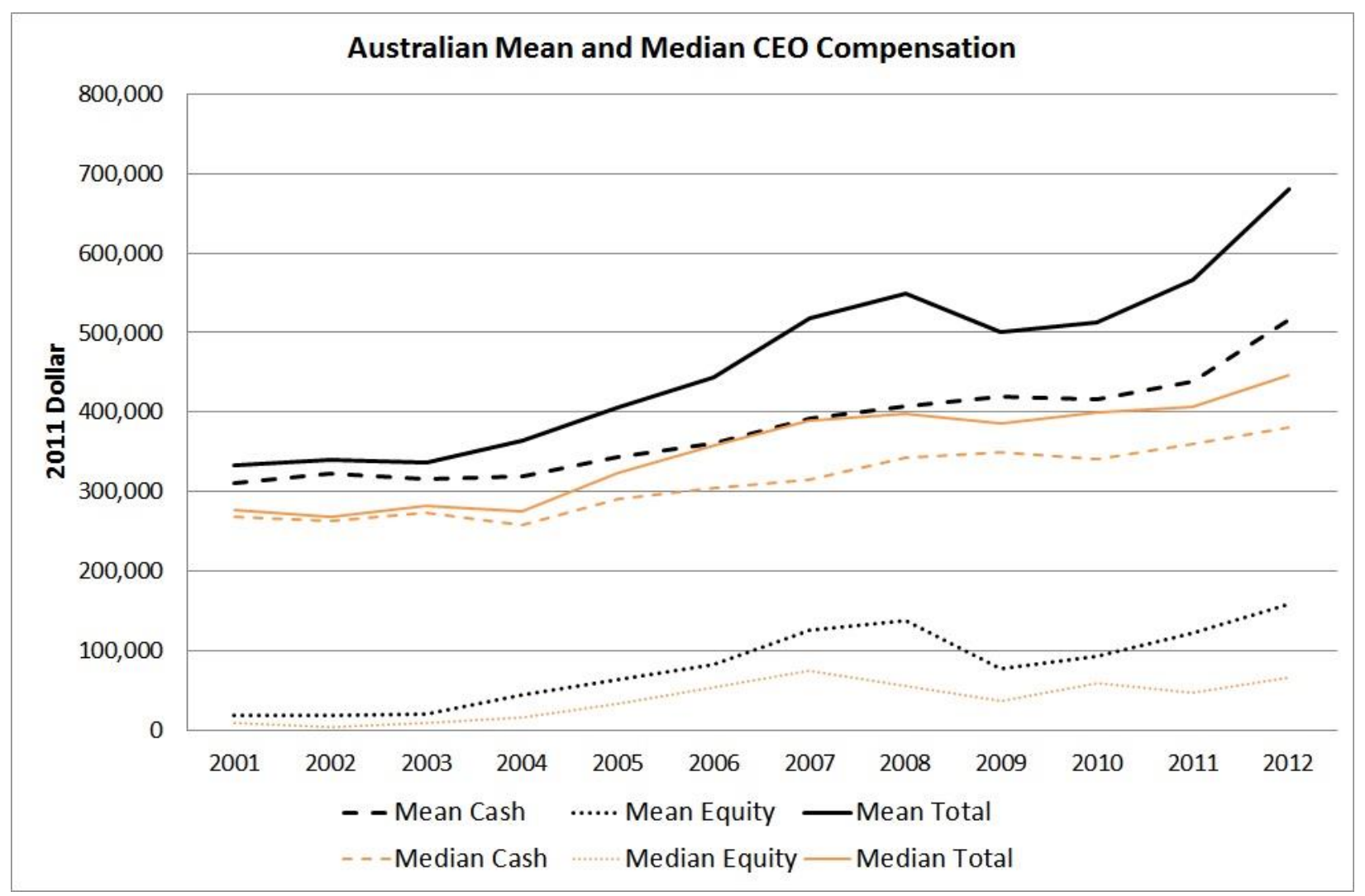


Figure 7: The distribution of alpha estimated from the CAPM model and the Fama-French three-factor model over the period of time during which the CEOs were in that position

Panel A: All CEOs for the CAPM model

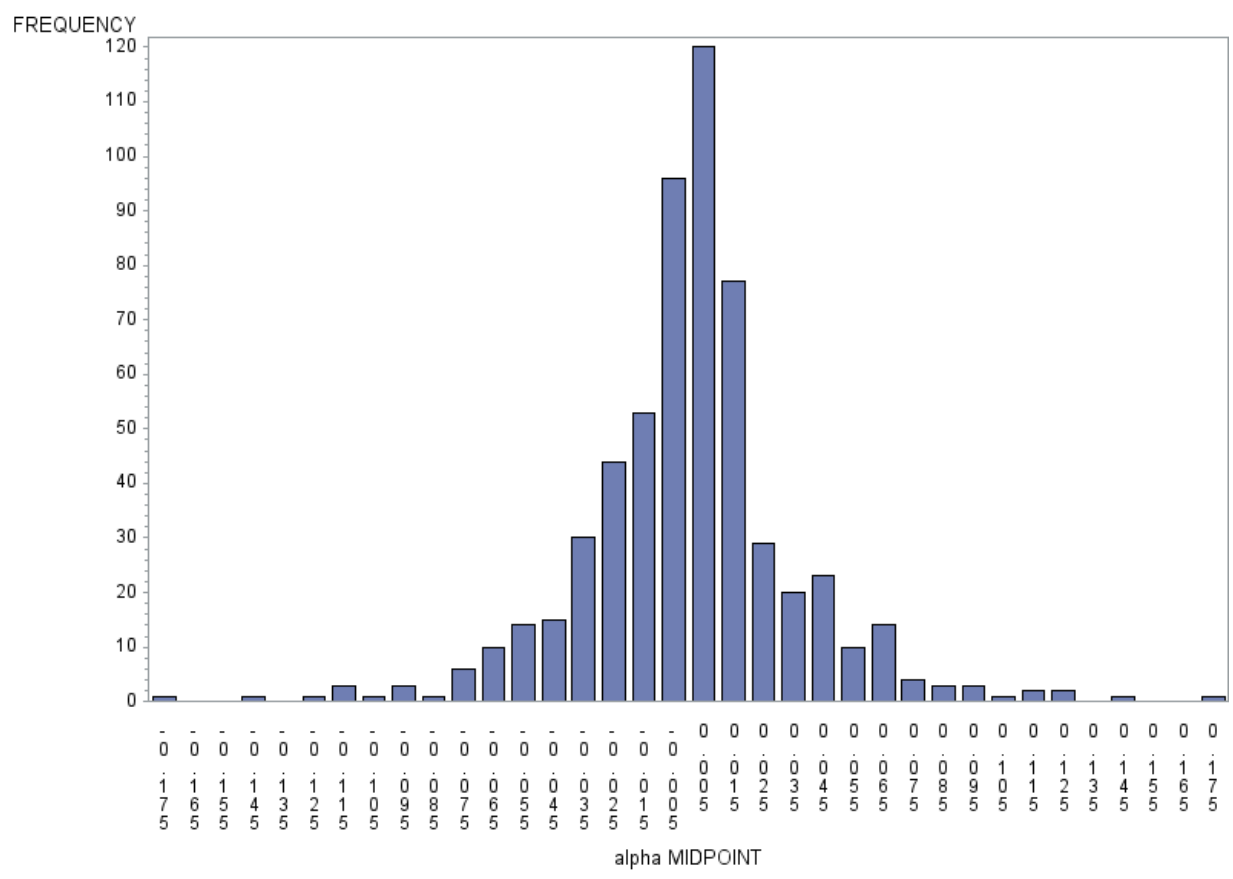

Panel B: All CEOs for the CAPM model (accounting for dividend imputation franking credits)

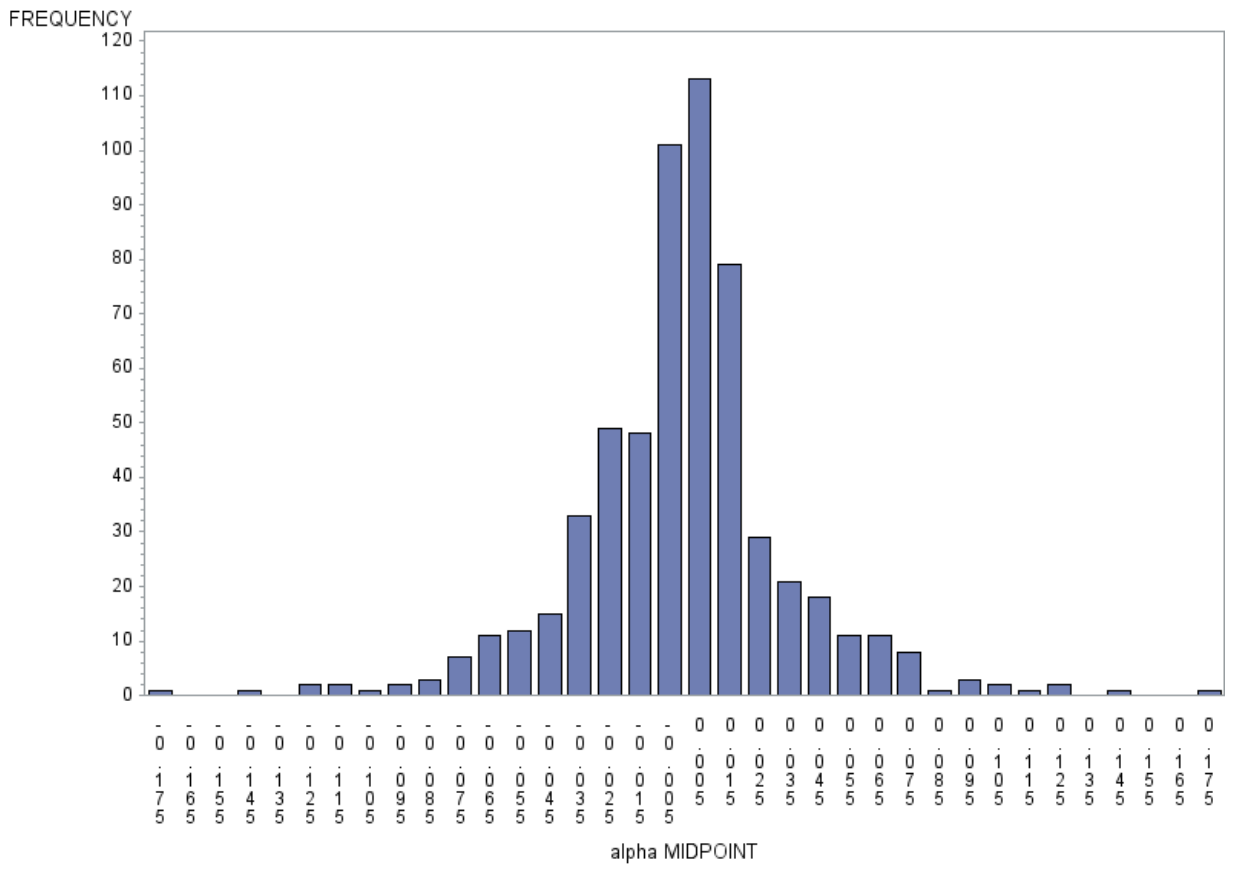


Panel C: All CEOs for the Fama-French three-factor model

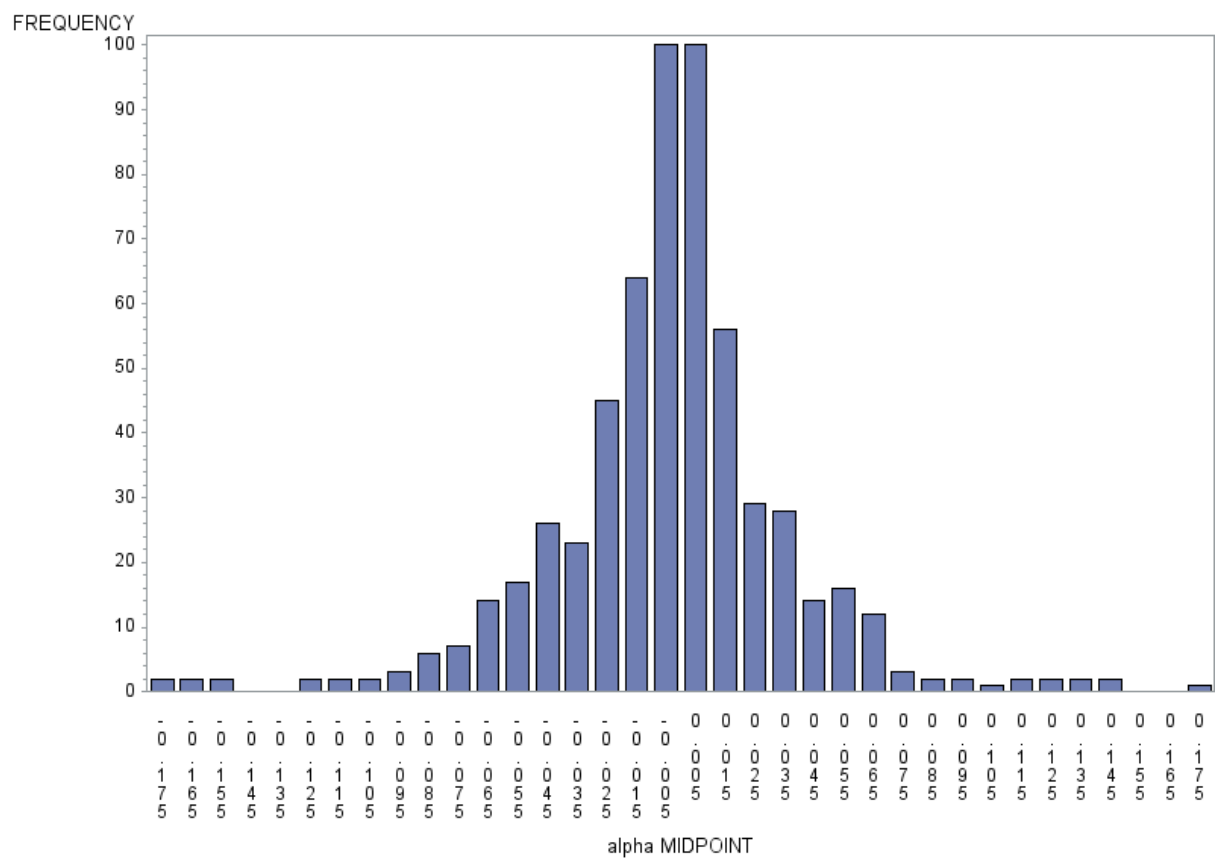

Panel D: All CEOs for the Fama-French three-factor model (accounting for dividend imputation franking credits)

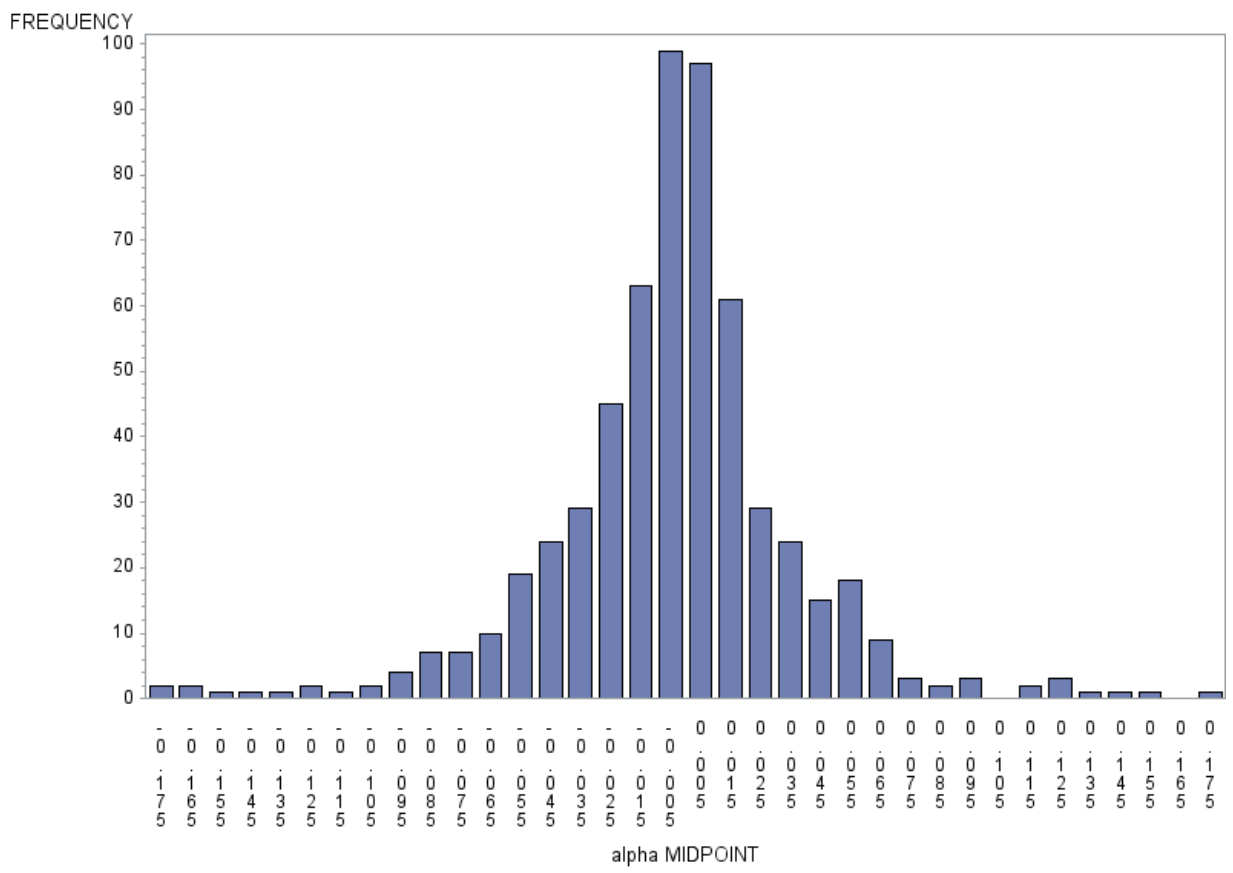


Figure 8: The distribution of alpha estimated from the CAPM model over the period of time during which the CEOs were in that position

Panel A: CEOs who had been in the position for more than three years

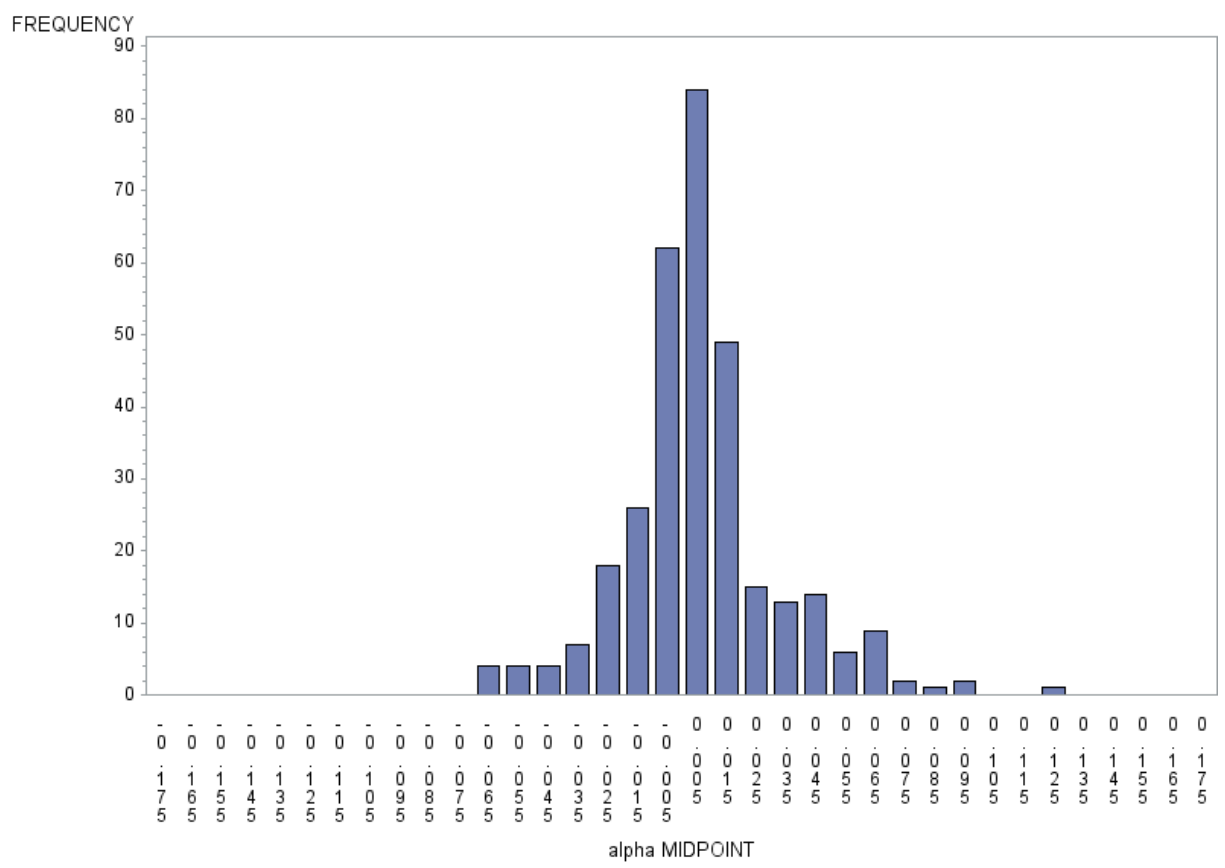

Panel B: CEOs who had been in the position for more than three years (accounting for dividend imputation franking credits)

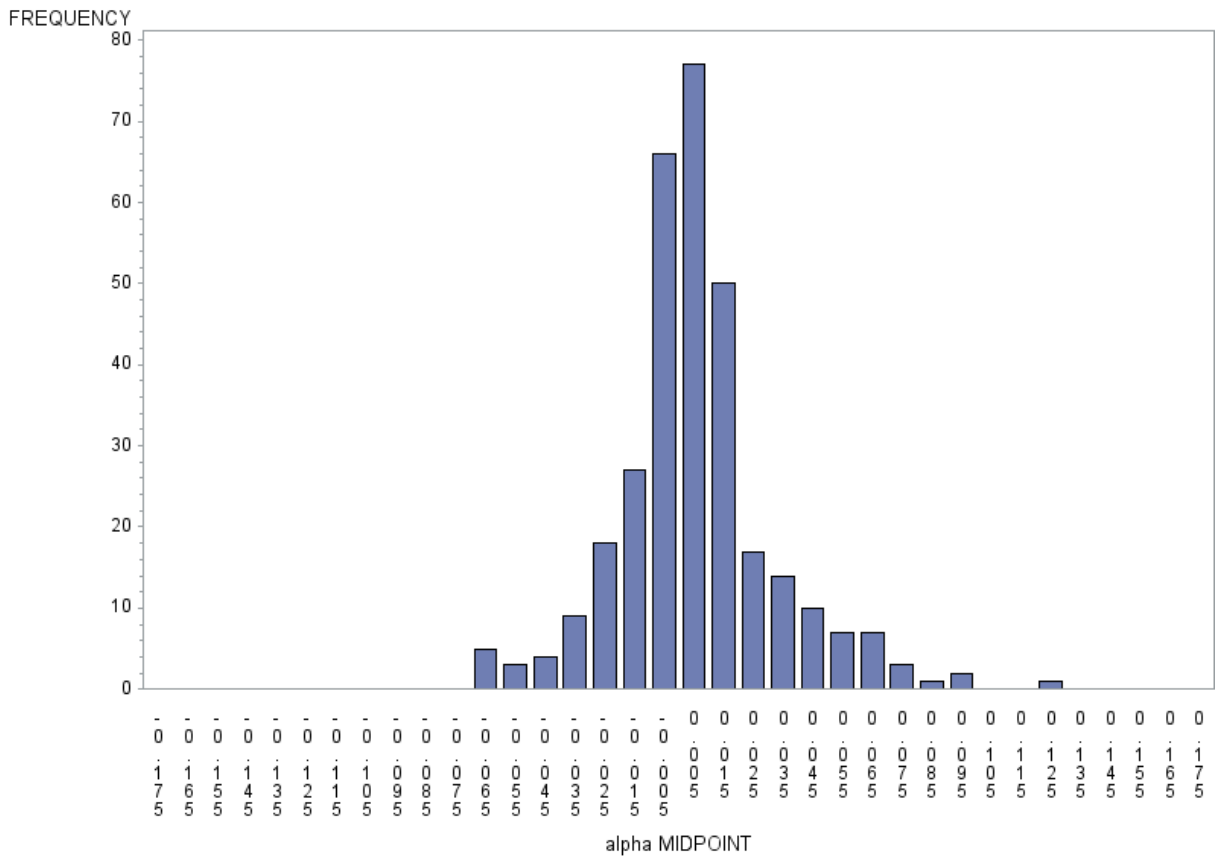


Panel C: CEOs who had been in the position for less than three years

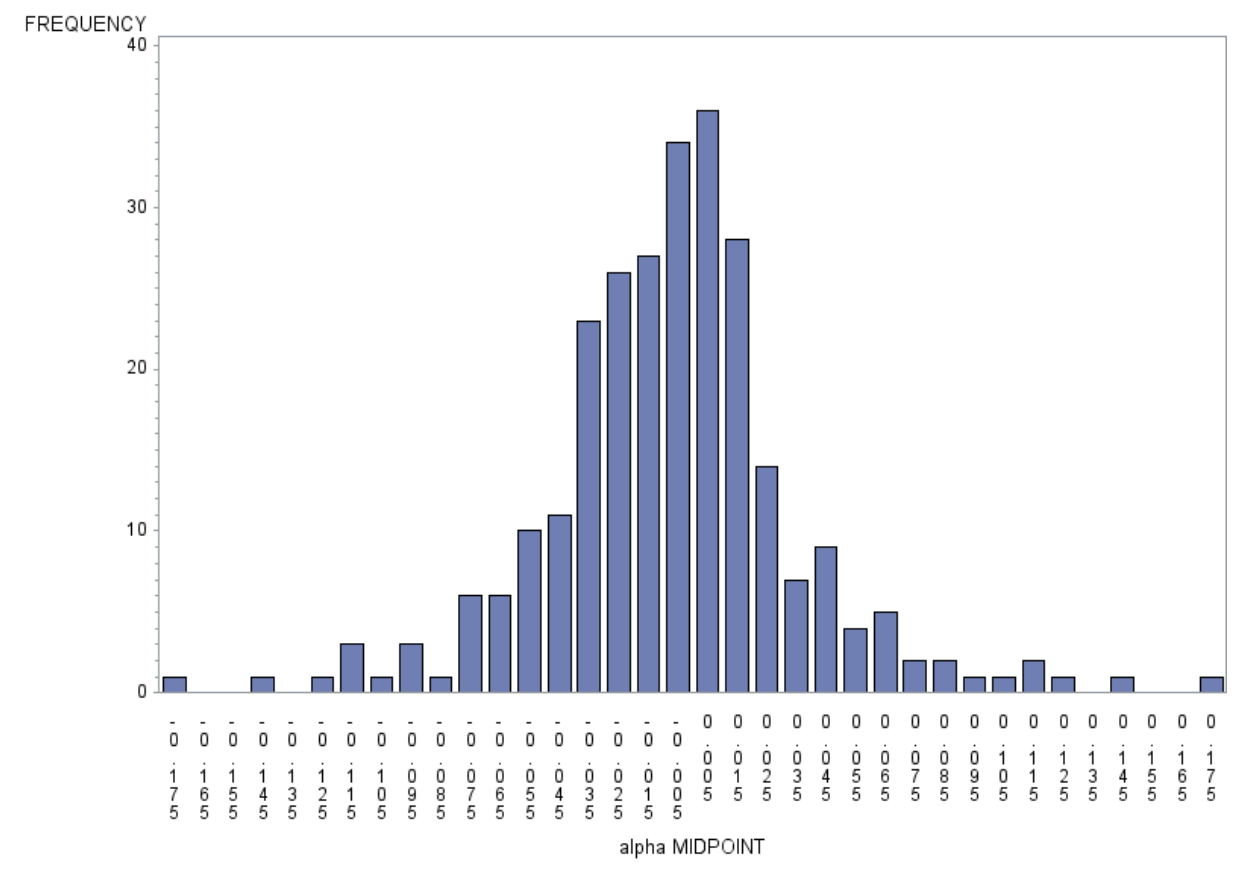

Panel D: CEOs who had been in the position for less than three years (accounting for dividend imputation franking credits)

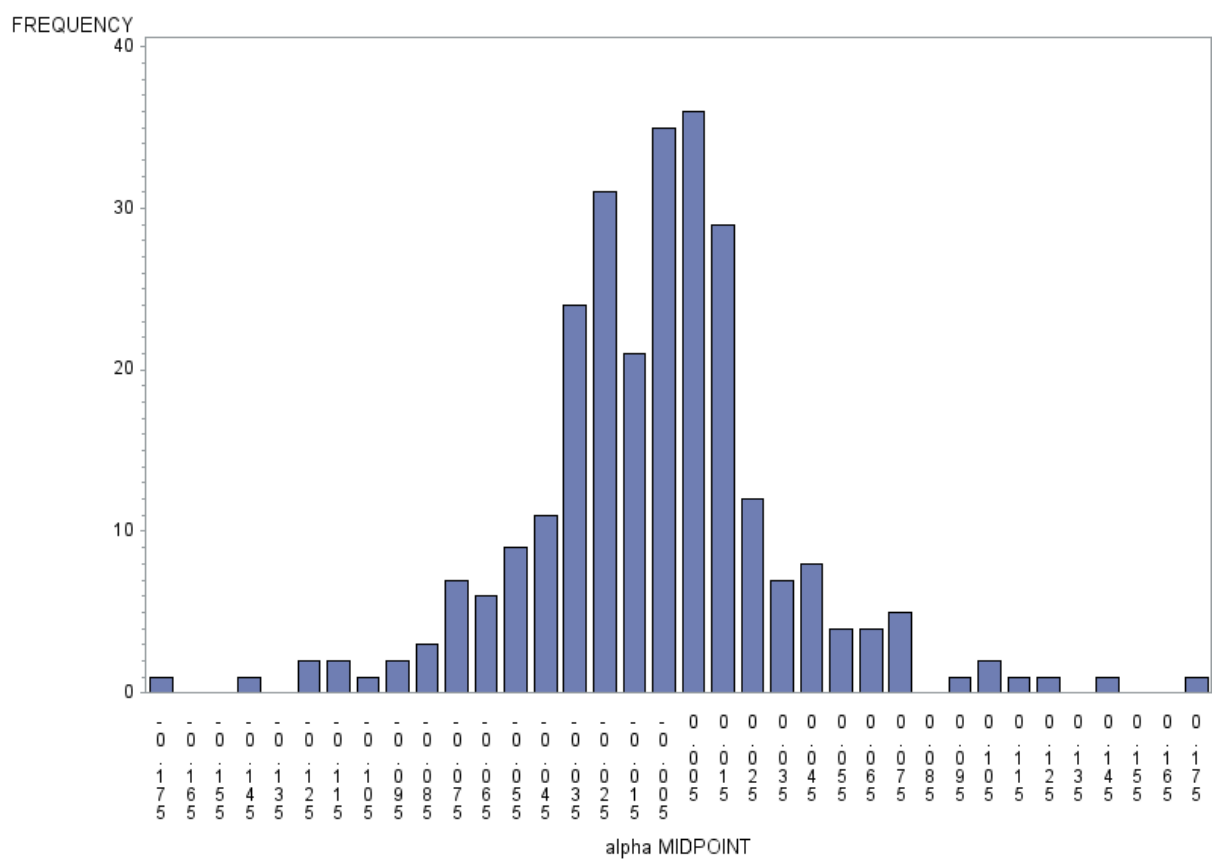


Figure 9: The distribution of alpha estimated from the Fama-French three-factor model over the period of time during which the CEOs were in that position

Panel A: CEOs who had been in the position for more than three years

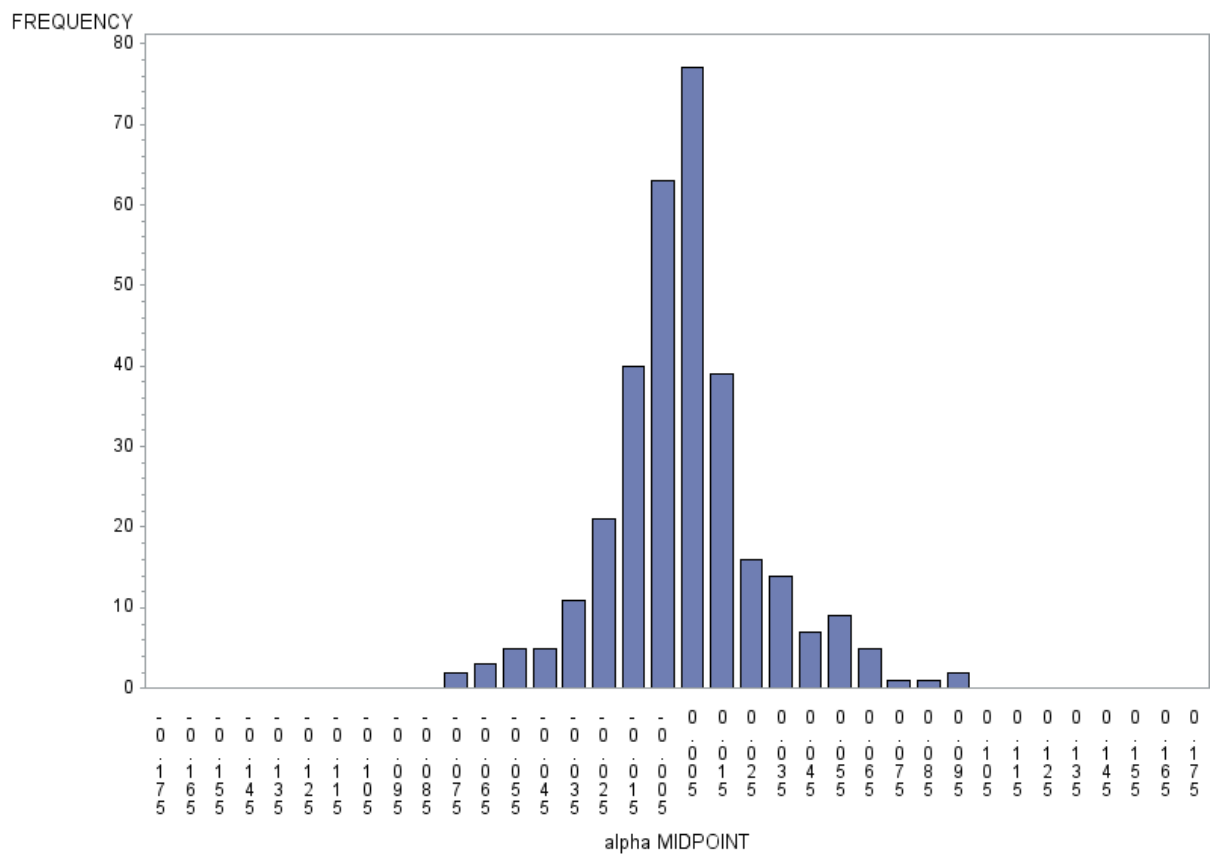

Panel B: CEOs who had been in the position for more than three years (accounting for dividend imputation franking credits)

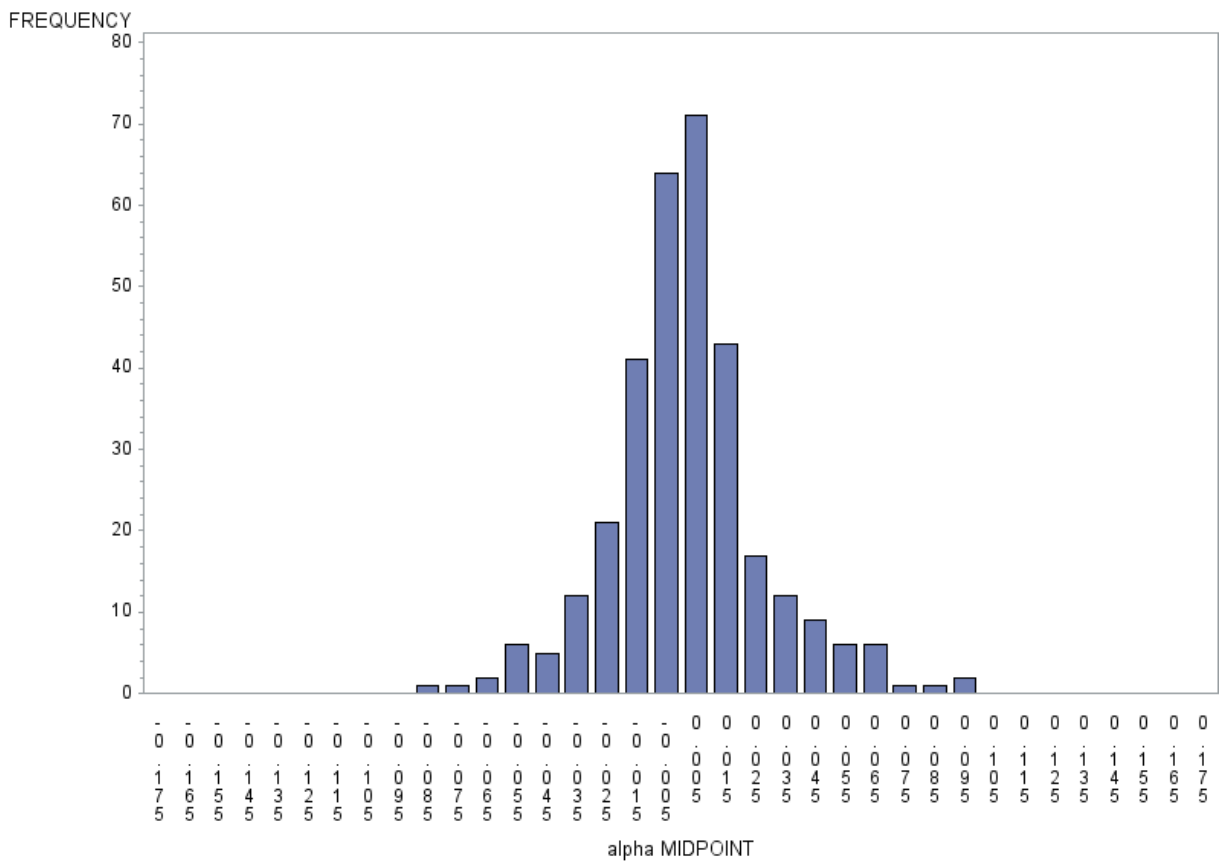


Panel C: CEOs who had been in the position for less than three years

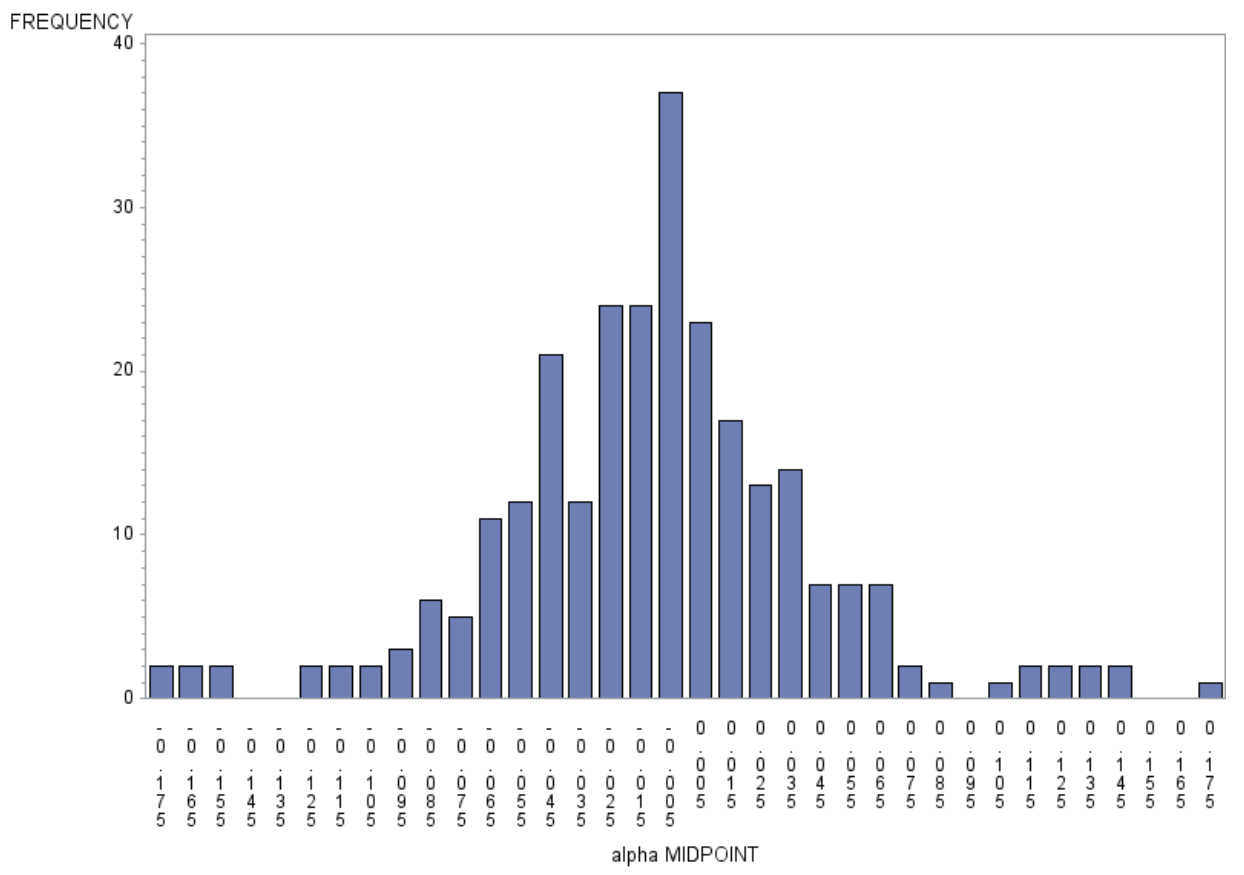

Panel D: CEOs who had been in the position for less than three years (accounting for dividend imputation franking credits)

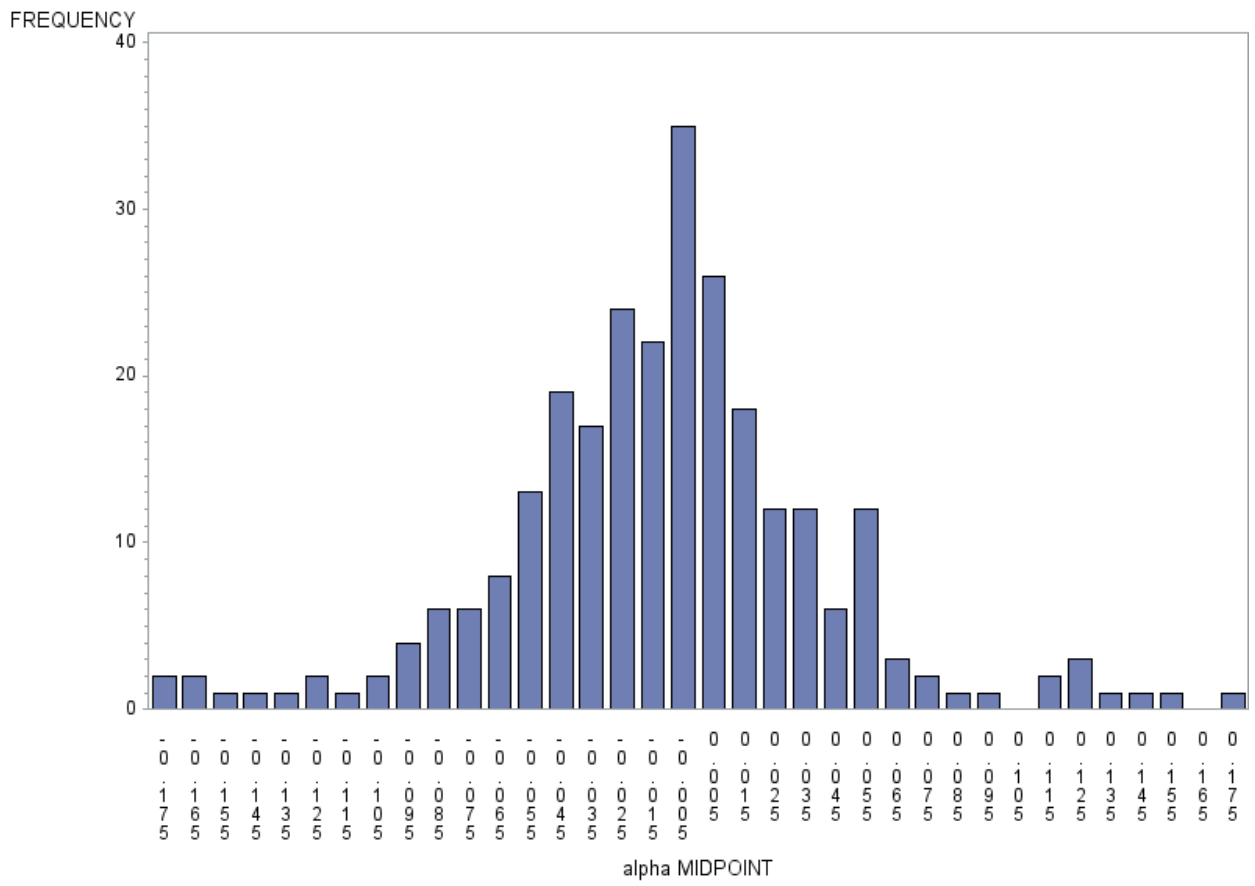




\section{REFERENCES}

Aggarwal, R.K. and A.A. Samwick (1999), 'The Other Side of the Trade-Off: The Impact of Risk on Executive Compensation', Journal of Political Economy, Vol. 107, No. 1, pp. 65-105.

Bebchuk, L. and Y. Grinstein (2005), 'The Growth of Executive Pay', Oxford Review of Economic Policy, Vol. 21, No. 2, pp. 283-303.

Bebchuk, L.A. and J.M. Fried (2003), 'Executive Compensation as an Agency Problem', The Journal of Economic Perspectives, Vol. 17, No. 3, pp. 71-92.

Bebchuk, L.A. and J.M. Fried (2004), 'Stealth Compensation via Retirement Benefits', Berkeley Business Law Journal, Vol. 1, No. 2, pp. 291-369.

Bebchuk, L.A. and J.M. Fried (2005), 'Pay without performance: Overview of the issues', Journal of Applied Corporate Finance, Vol. 17, No. 4, pp. 8-23.

Bebchuk, L.A. and J.M. Fried (2006), Pay without performance: The unfulfilled promise of executive compensation, Harvard University Press, Cambridge, MA.

Bebchuk, L.A., J.M. Fried and D.I. Walker (2002), 'Managerial Power and Rent Extraction in the Design of Executive Compensation', The University of Chicago Law Review, Vol. 69, pp. 751-846.

Bebchuk, L.A., Y. Grinstein and U. Peyer (2010), 'Lucky CEOs and Lucky Directors', The Journal of Finance, Vol. 65, No. 6, pp. 2363-2401.

Berle, A.A. and G.G.C. Means (1932), The modern corporation and private property, Macmillan, New York.

Bertrand, M. (2009), 'CEOs', Annual Review of Economics, Vol. 1, No. 1, pp. 121-150.

Bliss, R.T. and R.J. Rosen (2001), 'CEO Compensation and Bank Mergers', Journal of Financial Economics, Vol. 61, No. 1, pp. 107-138.

Brown, J.R., N. Liang and S. Weisbenner (2007), 'Executive Financial Incentives and Payout Policy: Firm Responses to the 2003 Dividend Tax Cut', The Journal of Finance, Vol. 62, No. 4, pp. 1935-1965.

Bugeja, M., R. Da Silva Rosa, L. Duong and H. Izan (2012), 'CEO Compensation from M\&As in Australia', Journal of Business Finance \& Accounting, Vol. 39, No. 9-10, pp. 1298-1329.

Cammer v. Bloom, (1989), 711 F.Supp. 1264, 1276 (D.N.J.).

Capezio, A., J. Shields and M. O'Donnell (2011), 'Too Good to be True: Board Structural Independence as a Moderator of CEO Pay-for-Firm-Performance', Journal of Management Studies, Vol. 48, No. 3, pp. 487-513.

Chalmers, K., P.-S. Koh and G. Stapledon (2006), 'The Determinants of CEO Compensation: Rent Extraction or Labour Demand?', The British Accounting Review, Vol. 38, No. 3, pp. 259-275.

Cho, M.-H. (1998), 'Ownership Structure, Investment, and the Corporate Value: An Empirical Analysis', Journal of Financial Economics, Vol. 47, No. 1, pp. 103-121.

Clarkson, P.M., J. Walker and S. Nicholls (2011), 'Disclosure, Shareholder Oversight and the PayPerformance Link', Journal of Contemporary Accounting \& Economics, Vol. 7, No. 2, pp. 47-64.

Coles, J.L., N.D. Daniel and L. Naveen (2006), 'Managerial Incentives and Risk-taking', Journal of Financial Economics, Vol. 79, No. 2, pp. 431-468. 
Coles, J.L., M.L. Lemmon and J. Felix Meschke (2012), 'Structural Models and Endogeneity in Corporate Finance: The Link between Managerial Ownership and Corporate Performance', Journal of Financial Economics, Vol. 103, No. 1, pp. 149-168.

Conyon, M.J., J.E. Core and W.R. Guay (2011), 'Are US CEOs Paid More than UK CEOs? Inferences from risk-adjusted pay', Review of Financial Studies, Vol. 24, No. 2, pp. 402-438.

Conyon, M.J. and K.J. Murphy (2000), 'The Prince and the Pauper? CEO Pay in the United States and United Kingdom', The Economic Journal, Vol. 110, No. 467, pp. 640-671.

Core, J.E. and D.F. Larcker (2002), 'Performance Consequences of Mandatory Increases in Executive Stock Ownership', Journal of Financial Economics, Vol. 64, No. 3, pp. 317-340.

Coulton, J. and S. Taylor (2002), 'Option Awards for Australian CEOs: The Who, What and Why', Australian Accounting Review, Vol. 12, No. 26, pp. 25-35.

Cybinski, P. and C. Windsor (2013), 'Remuneration Committee Independence and CEO Remuneration for Firm Financial Performance', Accounting Research Journal, Vol. 26, No. 3, pp. 197-221.

Datta, S., M. Iskandar-Datta and K. Raman (2001), 'Executive Compensation and Corporate Acquisition Decisions', The Journal of Finance, Vol. 56, No. 6, pp. 2299-2336.

Demsetz, H. and K. Lehn (1985), 'The Structure of Corporate Ownership: Causes and Consequences', The Journal of Political Economy, Vol. 93, No. 6, pp. 1155-1177.

Denis, D.J., D.K. Denis and A. Sarin (1997), 'Agency Problems, Equity Ownership, and Corporate Diversification', The Journal of Finance, Vol. 52, No. 1, pp. 135-160.

Doucouliagos, H., J. Haman and S. Askary (2007), 'Directors' Remuneration and Performance in Australian Banking', Corporate governance: an international review, Vol. 15, No. 6, pp. 13631383.

Edmans, A. and X. Gabaix (2009), 'Is CEO Pay Really Inefficient? A Survey of New Optimal Contracting Theories', European Financial Management, Vol. 15, No. 3, pp. 486-496.

Fenn, G.W. and N. Liang (2001), 'Corporate Payout Policy and Managerial Stock Incentives', Journal of Financial Economics, Vol. 60, No. 1, pp. 45-72.

Fernandes, N., M.A. Ferreira, P. Matos and K.J. Murphy (2013), 'Are US CEOs Paid More? New International Evidence', Review of Financial Studies, Vol. 26, No. 2, pp. 323-367.

Ferrarini, G., N. Moloney and M.C. Ungureanu (2009), Understanding directors' pay in Europe: A comparative and empirical analysis, Working Paper, European Corporate Governance Institute.

Frydman, C. (2007), Rising through the ranks: The evolution of the market for corporate executives, 1936-2003, Working Paper, Harvard University.

Frydman, C. and D. Jenter (2010), CEO compensation, Working Paper, National Bureau of Economic Research.

Frydman, C. and R.E. Saks (2010), 'Executive Compensation: A New View from a Long-term Perspective, 1936-2005', Review of Financial Studies, Vol. 23, No. 5, pp. 2099-2138.

Gabaix, X. and A. Landier (2008), 'Why Has CEO Pay Increased So Much?', The Quarterly Journal of Economics, Vol. 123, No. 1, pp. 49-100.

Gormley, T., D. Matsa and T. Milbourn (2014), 'CEO Compensation and Corporate Risk: Evidence from a Natural Experiment', Journal of accounting and economics, forthcoming. 
Grossman, S.J. and O.D. Hart (1983), 'An Analysis of the Principal-agent Problem', Econometrica: Journal of the Econometric Society, pp. 7-45.

Habib, M.A. and A. Ljungqvist (2005), 'Firm Value and Managerial Incentives: A Stochastic Frontier Approach', The Journal of Business, Vol. 78, No. 6, pp. 2053-2094.

Hall, B.J. and J.B. Liebman (1998), 'Are CEOs Really Paid Like Bureaucrats?', The Quarterly Journal of Economics, Vol. 113, No. 3, pp. 653-691.

Hall, B.J. and K.J. Murphy (2002), 'Stock Options for Undiversified Executives', Journal of accounting and economics, Vol. 33, No. 1, pp. 3-42.

Hall, B.J. and K.J. Murphy (2003), 'The Trouble with Stock Options', Journal of Economic Perspectives, Vol. 17, No. 3, pp. 49-70.

Harford, J. and K. Li (2007), 'Decoupling CEO Wealth and Firm Performance: The Case of Acquiring CEOs', The Journal of Finance, Vol. 62, No. 2, pp. 917-949.

Harris, M. and A. Raviv (1979), 'Optimal Incentive Contracts with Imperfect Information', Journal of Economic Theory, Vol. 20, No. 2, pp. 231-259.

Heaney, R., V. Tawani and J. Goodwin (2010), 'Australian CEO Remuneration*', Economic Papers: A Journal of Applied Economics and Policy, Vol. 29, No. 2, pp. 109-127.

Hill, J.G., R.W. Masulis and R.S. Thomas (2011), 'Comparing CEO Employment Contract Provisions: Differences between Australia and the United States', Vanderbilt Law Review, Vol. 64, 559-611.

Himmelberg, C.P., R.G. Hubbard and D. Palia (1999), 'Understanding the Determinants of Managerial Ownership and the Link between Ownership and Performance', Journal of Financial Economics, Vol. 53, No. 3, pp. 353-384.

Hirshleifer, D. and Y. Suh (1992), 'Risk, Managerial Effort, and Project Choice', Journal of Financial Intermediation, Vol. 2, No. 3, pp. 308-345.

Holland, P.J., P.J. Dowling and P.A. Innes (2001), 'CEO Compensation in Australia: Is there a Relationship between Principles, Policies and Practices?', Asia Pacific Journal of Human Resources, Vol. 39, No. 3, pp. 41-58.

Hölmstrom, B. (1979), 'Moral Hazard and Observability', The Bell Journal of Economics, pp. 74-91.

Holmstrom, B. and S.N. Kaplan (2001), 'Corporate Governance and Merger Activity in the United States: Making Sense of the 1980s and 1990s', Journal of Economic Perspectives, Vol. 15, No. 2, pp. 121144.

Izan, H., B. Sidhu and S. Taylor (1998), 'Does CEO Pay Reflect Performance? Some Australian Evidence', Corporate governance: an international review, Vol. 6, No. 1, pp. 39-47.

Jensen, M. and K. Murphy (2004), Remuneration: Where we've been, how we got to here, what are the problems, and how to fix them, Working Paper, European Corporate Governance Institute (ECGI).

Jensen, M.C. and W.H. Meckling (1976), 'Theory of the Firm: Managerial Behavior, Agency Costs and Ownership Structure', Journal of Financial Economics, Vol. 3, No. 4, pp. 305-360.

Jensen, M.C. and K.J. Murphy (1990), 'Performance Pay and Top-Management Incentives', The Journal of Political Economy, Vol. 98, No. 2, pp. 225-264.

Kaplan, S.N. (1994), 'Top Executive Rewards and Firm Performance: A Comparison of Japan and the 
United States', Journal of Political Economy, Vol. 102, No. 3, pp. 510-46.

Kaplan, S.N. (2013), 'CEO Pay and Corporate Governance in the US: Perceptions, Facts, and Challenges', Journal of Applied Corporate Finance, Vol. 25, No. 2, pp. 8-25.

Kaplan, S.N. and J. Rauh (2010), 'Wall Street and Main Street: What Contributes to the Rise in the Highest Incomes?', Review of Financial Studies, Vol. 23, No. 3, pp. 1004-1050.

Lee, J. (2009), 'Executive Performance-based Remuneration, Performance Change and Board Structures', The International Journal of Accounting, Vol. 44, No. 2, pp. 138-162.

Li, H., D. Henry and H.-I. Chou (2011), 'Stock Market Mispricing, Executive Compensation and Corporate Investment: Evidence from Australia', Journal of Behavioral Finance, Vol. 12, No. 3, pp. 131-140.

Loderer, C. and K. Martin (1997), 'Executive Stock Ownership and Performance Tracking Faint Traces', Journal of Financial Economics, Vol. 45, No. 2, pp. 223-255.

Low, A. (2009), 'Managerial Risk-taking Behavior and Equity-based Compensation', Journal of Financial Economics, Vol. 92, No. 3, pp. 470-490.

Matolcsy, Z., S. Riddell and A. Wright (2009), 'Alternative Explanations for the Association between Market Values and Stock-based Compensation Expenditure', Journal of Contemporary Accounting \& Economics, Vol. 5, No. 2, pp. 95-107.

Matolcsy, Z., Y. Shan and V. Seethamraju (2012), 'The Timing of Changes in CEO Compensation from Cash Bonus to Equity-based Compensation: Determinants and Performance Consequences', Journal of Contemporary Accounting \& Economics, Vol. 8, No. 2, pp. 78-91.

Matolcsy, Z. and A. Wright (2006), 'Are We Paying our CEOs too Much?', JASSA, Vol. 4, pp. 27-31.

Matolcsy, Z. and A. Wright (2007), 'Australian CEO Compensation: The Descriptive Evidence', Australian Accounting Review, Vol. 17, No. 43, pp. 47-59.

Matolcsy, Z. and A. Wright (2011), 'CEO Compensation Structure and Firm Performance', Accounting \& Finance, Vol. 51, No. 3, pp. 745-763.

Matolcsy, Z.P. (2000), 'Executive Cash Compensation and Corporate Performance During Different Economic Cycles*', Contemporary Accounting Research, Vol. 17, No. 4, pp. 671-692.

McConnell, J.J. and H. Servaes (1990), 'Additional Evidence on Equity Ownership and Corporate Value', Journal of Financial Economics, Vol. 27, No. 2, pp. 595-612.

Mehran, H. (1995), 'Executive Compensation Structure, Ownership, and Firm Performance', Journal of Financial Economics, Vol. 38, No. 2, pp. 163-184.

Merhebi, R., K. Pattenden, P.L. Swan and X. Zhou (2006), 'Australian Chief Executive Officer Remuneration: Pay and Performance', Accounting \& Finance, Vol. 46, No. 3, pp. 481-497.

Monem, R. and C. Ng (2013), 'Australia's 'Two-strikes' Rule and the Pay-performance Link: Are Shareholders Judicious?', Journal of Contemporary Accounting \& Economics, Vol. 9, No. 2, pp. 237-254.

Morck, R., A. Shleifer and R.W. Vishny (1988), 'Management Ownership and Market Valuation: An Empirical Analysis', Journal of Financial Economics, Vol. 20, pp. 293-315.

Murphy, K.J. (2013) 'Executive compensation: Where We Are, and How We Got There', Chapter 5 of Handbook of the Economics of Finance, 2(A) (2013), Edited by George M. Constantinides, Milton Harris and Rene M. Stulz. 
Murphy, K.J. (1985), 'Corporate Performance and Managerial Remuneration: An Empirical Analysis', Journal of accounting and economics, Vol. 7, No. 1, pp. 11-42.

Murphy, K.J. (1999), 'Executive Compensation', Handbook of labor economics, Vol. 3, pp. 2485-2563.

Murphy, K.J. (2002), 'Explaining executive compensation: Managerial Power versus the Perceived Cost of Stock Options', The University of Chicago Law Review, pp. 847-869. zzzzz

Murphy, K.J. (2003), 'Stock-based Pay in New Economy Firms', Journal of accounting and economics, Vol. 34, No. 1, pp. 129-147.

Murphy, K.J. and M.C. Jensen (2011), 'CEO Bonus Plans: And How to Fix Them', Working paper, USC Marshall School of Business, No. FBE 02-11.

Murphy, K.J. and J. Zabojnik (2008), Managerial Capital and the Market for CEOs, Working Paper, Queen's University, Department of Economics.

O'Neill, G.L. and M. lob (1999), 'Determinants of Executive Remuneration in Australian Organizations: An Exploratory Study', Asia Pacific Journal of Human Resources, Vol. 37, No. 1, pp. 65-75.

Palia, D. (2001), 'The Endogeneity of Managerial Compensation in Firm Valuation: A Solution', Review of Financial Studies, Vol. 14, No. 3, pp. 735-764.

Piketty, T. and E. Saez (2003), 'Income Inequality in the United States, 1913-1998', The Quarterly Journal of Economics, Vol. 118, No. 1, pp. 1-41.

Piketty, T. and E. Saez (2006), The evolution of top incomes: a historical and international perspective, Working Paper, National Bureau of Economic Research.

Pottenger, M. and A. Leigh (2013), Long Run Trends in Australian Executive Remuneration: BHP 18872012.

Productivity Commission (2009), Executive remuneration in Australia.

Rose, N.L. and C. Wolfram (2002), 'Regulating Executive Pay: Using the Tax Code to Influence Chief Executive Officer Compensation', Journal of Labor Economics, Vol. 20, No. S2, pp. S138-S175.

Schultz, E., G.Y. Tian and G. Twite (2013), 'Corporate Governance and the CEO Pay-Performance Link: Australian Evidence', International Review of Finance, Vol. 13, No. 4, pp. 447-472.

Shleifer, A. and R.W. Vishny (1997), 'A Survey of Corporate Governance', The Journal of Finance, Vol. 52, No. 2, pp. 737-783.

Smith, C.W. and R.M. Stulz (1985), 'The Determinants of Firms' Hedging Policies', Journal of financial and quantitative analysis, Vol. 20, No. 4, pp. 391-405.

Smith, C.W. and R.L. Watts (1982), 'Incentive and Tax Effects of Executive Compensation Plans', Australian Journal of Management, Vol. 7, No. 2, pp. 139-157.

Utz, C. (2012), 'Executive Employment Contracts - Compliance and Risk Issues. Guidance for Boards and Senior Executives in Australia [online]', Clayton Utz, retrieved.from: http://www.claytonutz.com/docs/ExecutiveEmploymentContractsComplianceandRisklssues.pdf

Villalonga, B. and R. Amit (2006), 'How Do Family Ownership, Control and Management Affect Firm Value?', Journal of Financial Economics, Vol. 80, No. 2, pp. 385-417.

Walker, J. (2010), 'The Use of Performance-based Remuneration: High versus Low-growth Firms', Australian Accounting Review, Vol. 20, No. 3, pp. 256-264. 
Yermack, D. (1995), 'Do Corporations Award CEO Stock Options Effectively?', Journal of Financial Economics, Vol. 39, No. 2, pp. 237-269.

Yermack, D. (1997), 'Good Timing: CEO Stock Option Awards and Company News Announcements', The Journal of Finance, Vol. 52, No. 2, pp. 449-476.

Yermack, D. (2006), 'Flights of Fancy: Corporate Jets, CEO Perquisites, and Inferior Shareholder Returns', Journal of Financial Economics, Vol. 80, No. 1, pp. 211-242.

Yermack, D. (2006), 'Golden Handshakes: Separation Pay for Retired and Dismissed CEOs', Journal of accounting and economics, Vol. 41, No. 3, pp. 237-256.

Yermack, D. (2009), 'Deductio'ad Absurdum: CEO's Deonating their Own Stock to their Own Family Foundations', Journal of Financial Economics, Vol. 94, No. 1, pp. 107-123. 